\title{
Electron-Rich Phenoxyl Mediators Improve Thermodynamic Performance of Electrocatalytic Alcohol Oxidation with an Iridium Pincer Complex
}

Conor M. Galvin and Robert M. Waymouth*

Department of Chemistry, Stanford University, Stanford, CA, 94305

*waymouth@stanford.edu

\section{Supplementary Information}

\section{Table of Contents}

Materials

Instrumentation

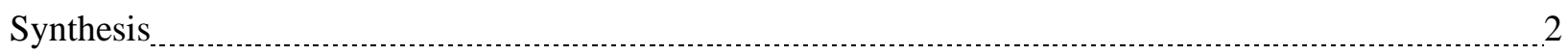

Definitions

Cyclic Voltammetry of $\mathrm{P}_{2}$-Et and IrH 2

Bulk Electrocatalytic Alcohol Oxidations

Non-Electrochemical Reactions

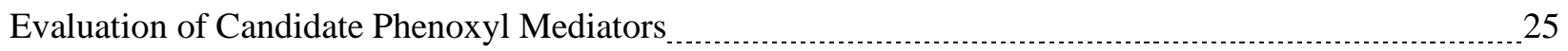

Calculation of $\mathrm{k}_{\mathrm{obs}}$ and $\mathrm{k}_{1}$ for ECHAT with $\mathrm{Ar}^{2} \mathrm{OH}, \mathrm{Ar}^{3} \mathrm{OH}$, and $\mathrm{Ar}^{4} \mathrm{OH}$

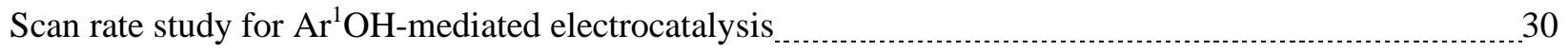

Derivation of the TOF and Plateau Current Formulas for Phenoxyl-Mediated Electrocatalysis _ _ 31

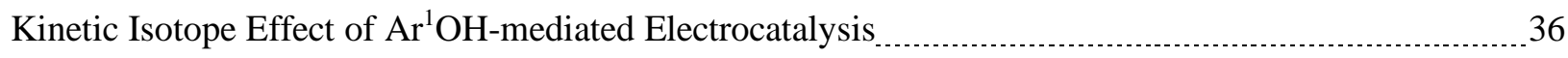

Foot-of-the-wave Analysis _ 37

Ruling out PT-ET and ET-PT as mechanisms of IrH 2 oxidation by $\mathbf{A r}^{4} \mathbf{O} \cdot \ldots$

Calculation of Theoretical Maximum Kinetic Isotope Effects for $\mathrm{N}-\mathrm{H}$ and $\mathrm{Ir}-\mathrm{H}$ Homolyses $\ldots . . . . . . . . .43$

Cyclic Voltammetry of ECAT and ECHAT in neat Isopropanol

References 


\section{Materials}

All manipulations were performed under inert nitrogen atmosphere using standard vacuum line, Schlenk, and glovebox techniques. Dry and degassed solvents were either obtained from an inert solvent drying system or purified with $3 \AA$ molecular sieves and three cycles of freeze-pump-thawing. Deuterated solvents for NMR experiments were purchased from Cambridge Isotope Labs. All other reagents were used as received except for ferrocene and TEMPO, both of which were sublimed under vacuum and stored under inert atmosphere.

\section{Instrumentation}

NMR spectra were recorded using Varian 300, 400, 500, and $600 \mathrm{MHz}$ spectrometers. ${ }^{1} \mathrm{H}$ NMR with solvent suppression was performed on a $600 \mathrm{MHz}$ spectrometer. All NMR were taken at room temperature. Residual solvent proton peaks were used as reference. Chemical shifts are reported in parts per million.

All electrochemical experiments were performed using a WaveNow USB potentiostat from Pine Research Instrumentation at ambient temperature (292 K) in a nitrogen-filled glovebox. Cyclic voltammetry experiments were executed in undivided three-electrode cells. The working electrode was a $3 \mathrm{~mm}$ diameter glassy carbon disk (Bioanalytical Systems, Inc.), the counter electrode was a platinum wire, and the $\mathrm{Ag} / \mathrm{AgNO}_{3}$ reference electrode contained a silver wire and $10 \mathrm{mM} \mathrm{AgNO} 3$ and $100 \mathrm{mM} \mathrm{NBu}_{4} \mathrm{BF}_{4}$ in acetonitrile. The glassy carbon working electrode was polished with diamond polishing suspension between each experiment. Potentials are referenced to the $\mathrm{Fc}^{0 /+}$ couple $(0.0 \mathrm{~V})$. Except where indicated otherwise, a scan rate of $v=25 \mathrm{mV} / \mathrm{s}$ was used. Bulk electrocatalytic alcohol oxidations were performed in a divided glass H-cell. Disposable pieces of Duocell@ reticulated vitreous carbon (ERG Materials and Aerospace) were used as working and counter electrodes for these experiments, as was the same reference electrode used in the cyclic voltammetry experiments.

\section{Synthesis}

The iridium transfer hydrogenation catalysts $\operatorname{IrN} \mathbf{1}$ and $\operatorname{IrH} \mathbf{2}$ were synthesized according to literature procedures. ${ }^{1}$ The persistent phenoxyl 2,4,6-tri-tert-butylphenoxyl $\mathbf{A} \mathbf{r}^{3} \mathbf{O}$ - was synthesized according to the method described by Mayer et al. ${ }^{2}$

\section{Definitions}

Turnover Frequency $\left(k_{o b s}\right)$ - Turnover frequency in the context of ECHAT is always defined as the number of equivalents of acetone produced per equivalent of phenoxyl catalyst per unit time.

Onset Potential $\left(E_{\text {onset }}\right)$ - The potential at which the extrapolation of the linear portion of the CV baseline and the extrapolation of the linear portion of the electrochemical wave intersect one another. 


\section{Cyclic Voltammetry of $\mathbf{P}_{2}$-Et and IrH 2}

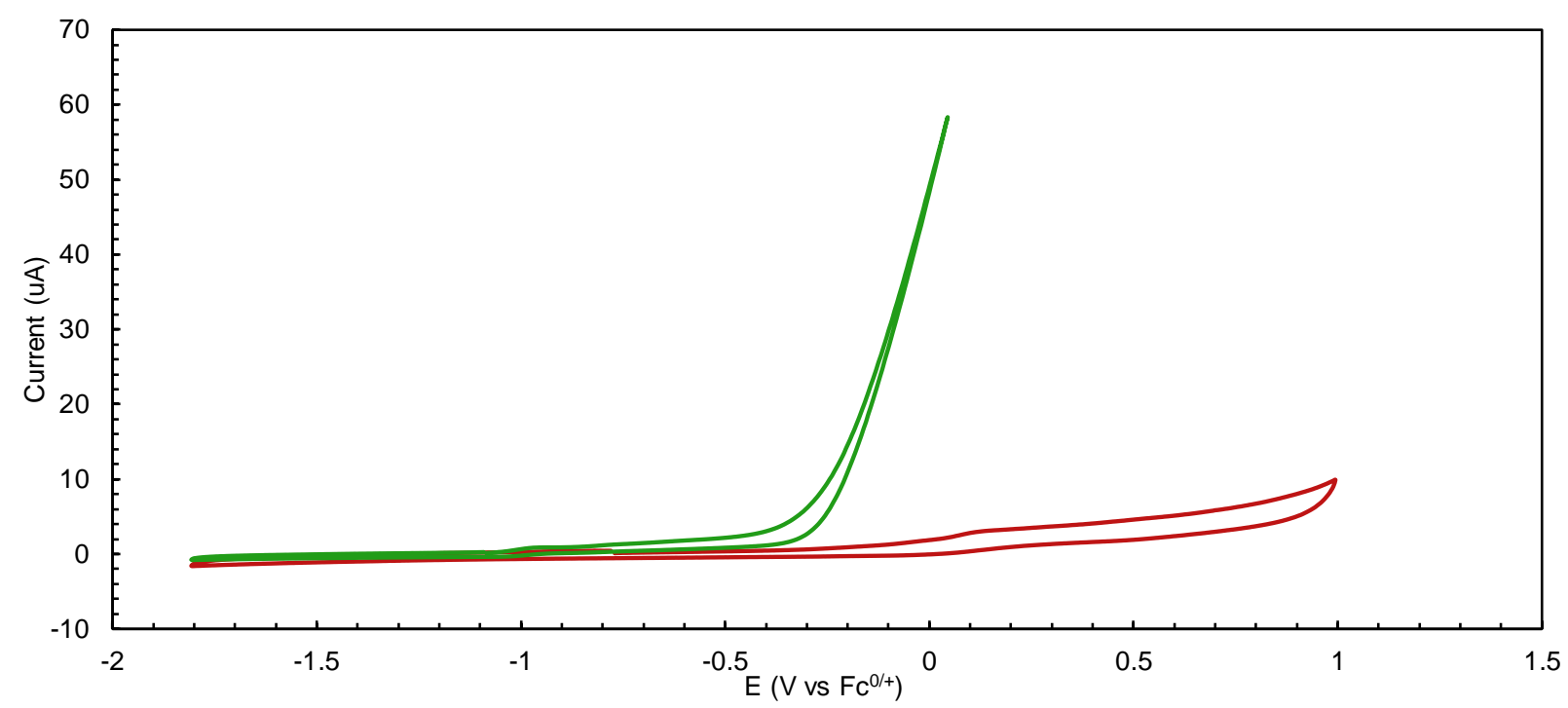

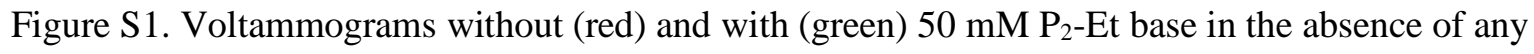
iridium species (480 $\mathrm{mM}$ isopropanol, $100 \mathrm{mM} \mathrm{NBu}_{4} \mathrm{BF}_{4}$ in THF, $v=25 \mathrm{mV} / \mathrm{s}$ )

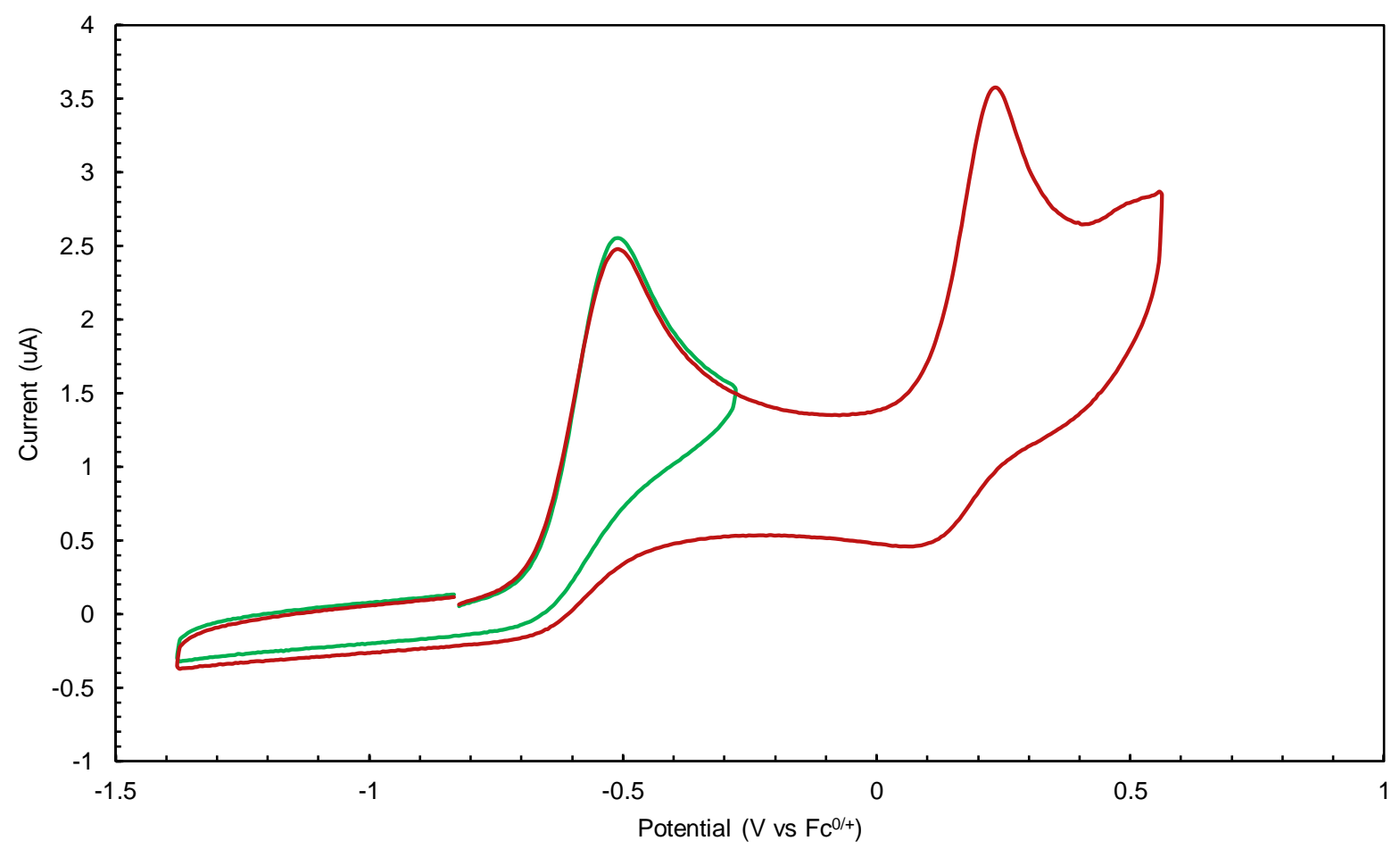

Figure S2. Voltammogram of IrH 2 in the absence of $\mathrm{P}_{2}$-Et base ( $350 \mathrm{mM}$ isopropanol, $100 \mathrm{mM} \mathrm{NBu}_{4} \mathrm{BF}_{4}$ in THF, $v=25 \mathrm{mV} / \mathrm{s}$ ) 


\section{Bulk Electrocatalytic Alcohol Oxidations}

Controlled-potential electrocatalytic alcohol oxidations under both unmediated and phenoxylmediated conditions were performed in a divided glass $\mathrm{H}$-cell. The working compartment contained a stir bar, a reference electrode containing a silver wire and $10 \mathrm{mM} \mathrm{AgNO}_{3}$ and $100 \mathrm{mM} \mathrm{NBu}_{4} \mathrm{BF}_{4}$ in acetonitrile, and a disposable reticulated vitreous carbon (RVC) working electrode. The counter compartment contained a stir bar and a disposable RVC counter electrode. Both electrodes were massed prior to the electrolysis in order to verify that the counter electrode was larger than the working electrode. This was done to ensure that the counter process was not current-limiting. Both compartments were sealed with rubber septa to prevent evaporation. The headspaces of the two compartments were connected with a small cannula to equilibrate the headspace pressure.

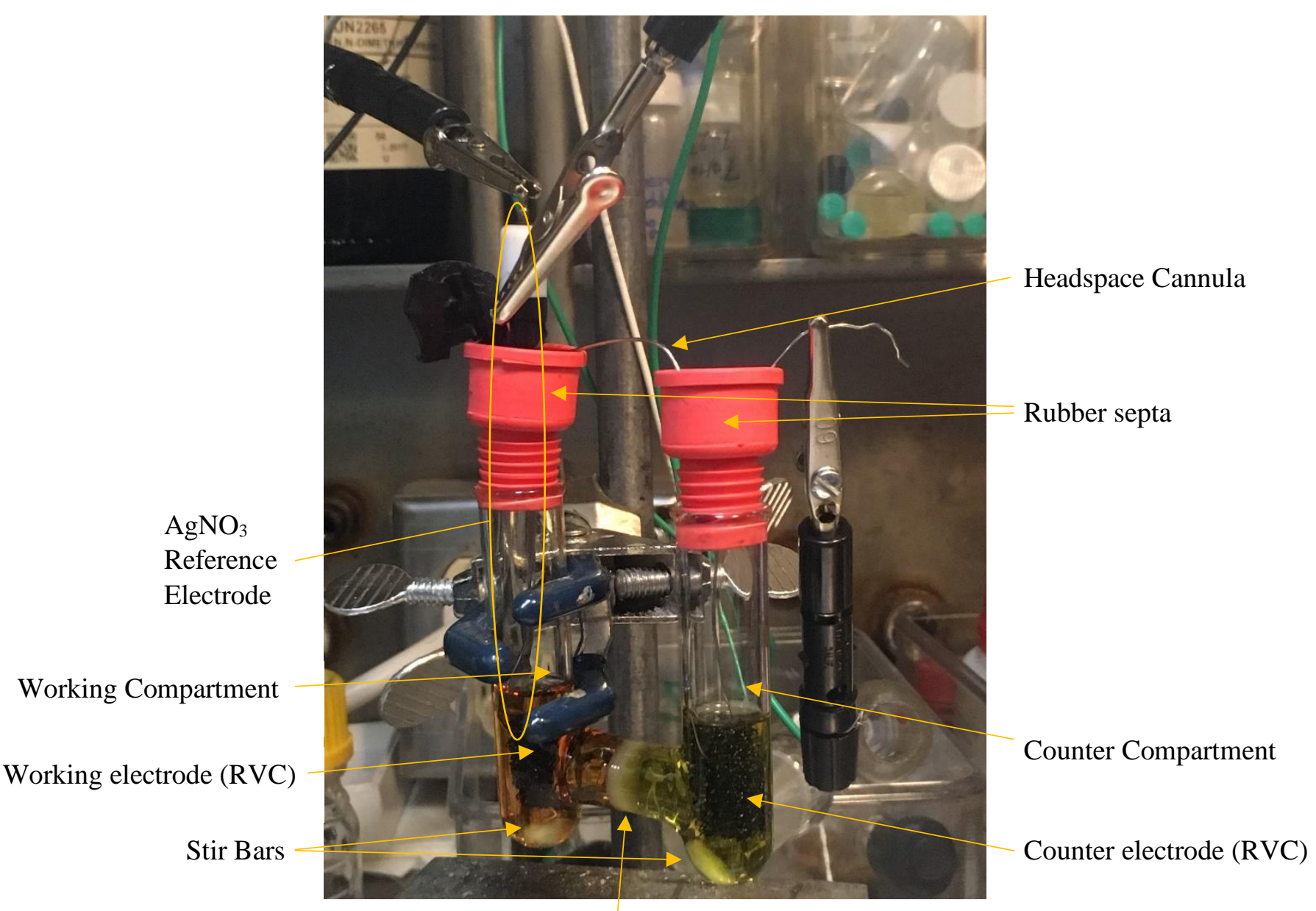

Glass Frit

Figure S3. Divided glass H-cell apparatus for controlled-potential electrocatalytic alcohol oxidations 


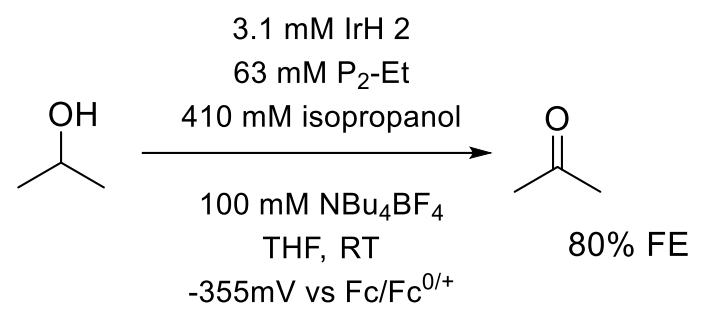

Unmediated Electrocatalytic Oxidation of Isopropanol with IrH 2 (Run \#1). The working compartment of the divided glass $\mathrm{H}$-cell was charged with $4.5 \mathrm{~mL}$ of $3.1 \mathrm{mM} \mathrm{IrH} \mathrm{,} 63 \mathrm{mM} \mathrm{P}$-Et phosphazene base, 0.41 $\mathrm{M}$ isopropanol, and $100 \mathrm{mM} \mathrm{NBu}_{4} \mathrm{BF}_{4}$ in THF. The counter compartment was filled with $4.5 \mathrm{~mL}$ of 63 $\mathrm{mM} \mathrm{P}_{2}$-Et phosphazene base, $0.41 \mathrm{M}$ isopropanol, and $100 \mathrm{mM} \mathrm{NBu}_{4} \mathrm{BF}_{4}$ in THF. The surface areas of the RVC working and counter electrodes were $17.0 \mathrm{~cm}^{2}$ and $18.4 \mathrm{~cm}^{2}$, respectively. The potential of the cell was set at $-355 \mathrm{mV}$ vs $\mathrm{Fc}^{0 /+}$, the compartments were sealed with septa, and the reaction was stirred at ambient temperature. Following the conclusion of the electrolysis after $6.48 \mathrm{hr}, 900 \mu \mathrm{L}$ of the working compartment solution was combined with $100 \mu \mathrm{L}$ of a $100 \mathrm{mM}$ solution of 1,3,5-trimethoxybenzene in $\mathrm{C}_{6} \mathrm{D}_{6}$ as internal standard. Product conversion was quantified with ${ }^{1} \mathrm{H}$ NMR spectroscopy with suppression of solvent signals. Comparison of the acetone methyl peak to the internal standard aryl peak indicates $0.056 \mathrm{mmol}$ real acetone in the working compartment (TON $=4.0)$. Integration of the current vs time plot showed $13.37 \mathrm{C}$ of charge were passed, which corresponds to $0.070 \mathrm{mmol}$ expected acetone and a Faradaic Efficiency of $80 \% \pm 10 \%$.

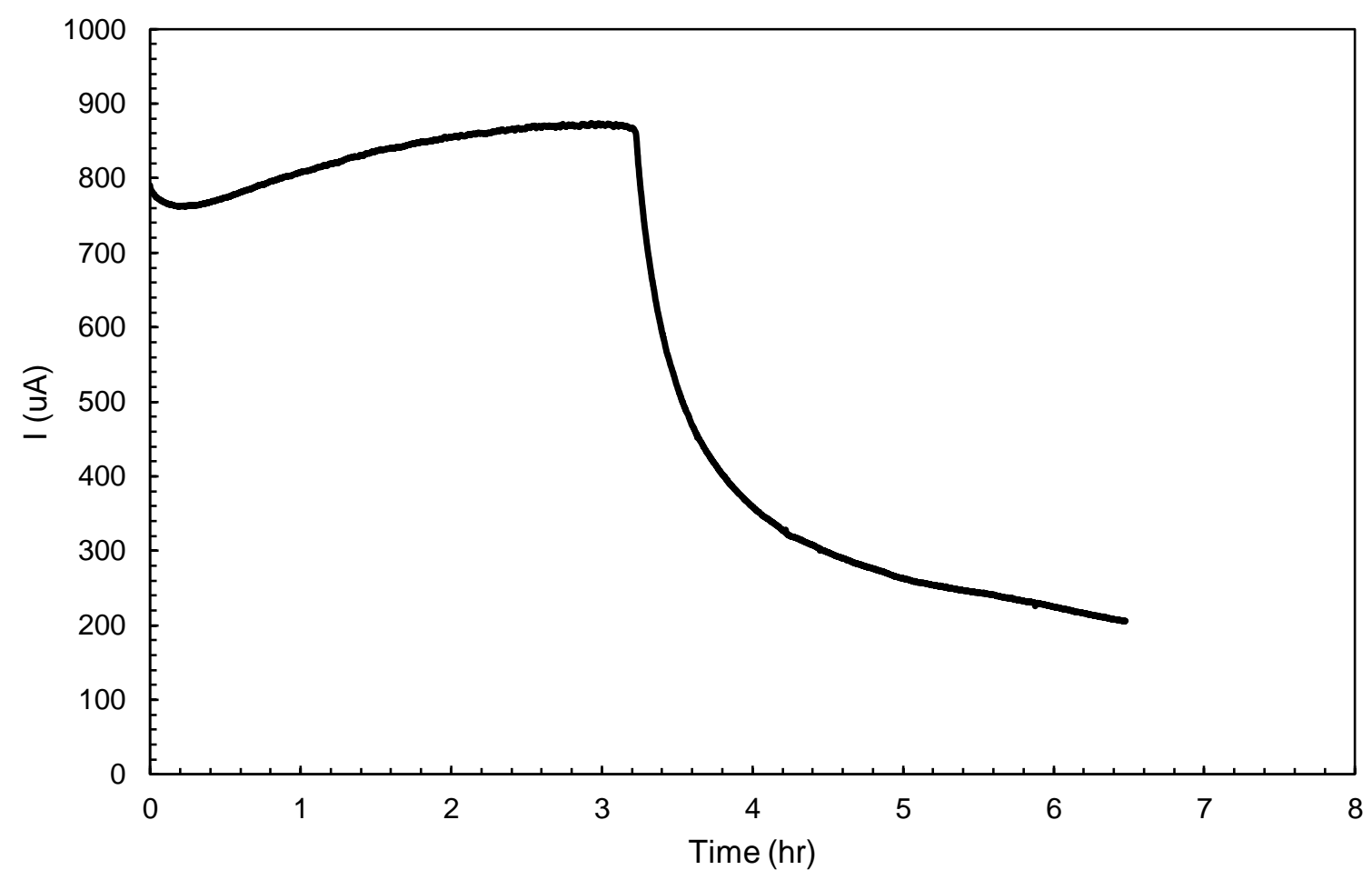

Figure S4. Current vs time plot for the bulk electrocatalytic oxidation of isopropanol to acetone under unmediated conditions (Run \#1) 


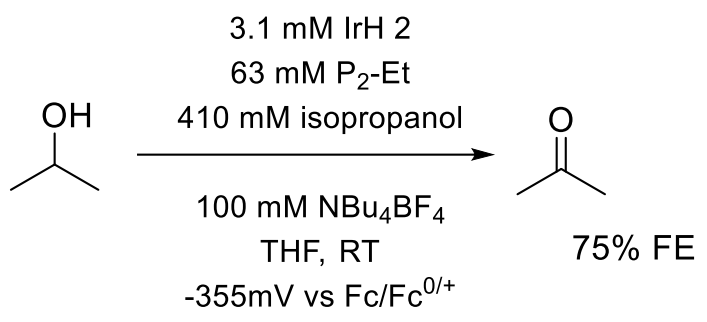

Unmediated Electrocatalytic Oxidation of Isopropanol with IrH 2 (Run \#2). The working compartment of the divided glass $\mathrm{H}$-cell was charged with $4.5 \mathrm{~mL}$ of $3.1 \mathrm{mM} \mathrm{IrH} \mathrm{2,} 63 \mathrm{mM} \mathrm{P} \mathrm{P}_{2}$-Et phosphazene base, 0.41 $\mathrm{M}$ isopropanol, and $100 \mathrm{mM} \mathrm{NBu}_{4} \mathrm{BF}_{4}$ in THF. The counter compartment was filled with $4.5 \mathrm{~mL}$ of 63 $\mathrm{mM} \mathrm{P}_{2}$-Et phosphazene base, $0.41 \mathrm{M}$ isopropanol, and $100 \mathrm{mM} \mathrm{NBu}_{4} \mathrm{BF}_{4}$ in THF. The surface areas of the RVC working and counter electrodes were $16.4 \mathrm{~cm}^{2}$ and $18.9 \mathrm{~cm}^{2}$, respectively. The potential of the cell was set at $-355 \mathrm{mV}$ vs $\mathrm{Fc}^{0 /+}$, the compartments were sealed with septa, and the reaction was stirred at ambient temperature. Following the conclusion of the electrolysis after $6.32 \mathrm{hr}, 900 \mu \mathrm{L}$ of the working compartment solution was combined with $100 \mu \mathrm{L}$ of a $100 \mathrm{mM}$ solution of 1,3,5-trimethoxybenzene in $\mathrm{C}_{6} \mathrm{D}_{6}$ as internal standard. Product conversion was quantified with ${ }^{1} \mathrm{H}$ NMR spectroscopy with suppression of solvent signals. Comparison of the acetone methyl peak to the internal standard aryl peak indicates $0.048 \mathrm{mmol}$ real acetone in the working compartment (TON =3.4). Integration of the current vs time plot showed $12.26 \mathrm{C}$ of charge were passed, which corresponds to $0.064 \mathrm{mmol}$ expected acetone and a Faradaic Efficiency of $75 \% \pm 10 \%$.

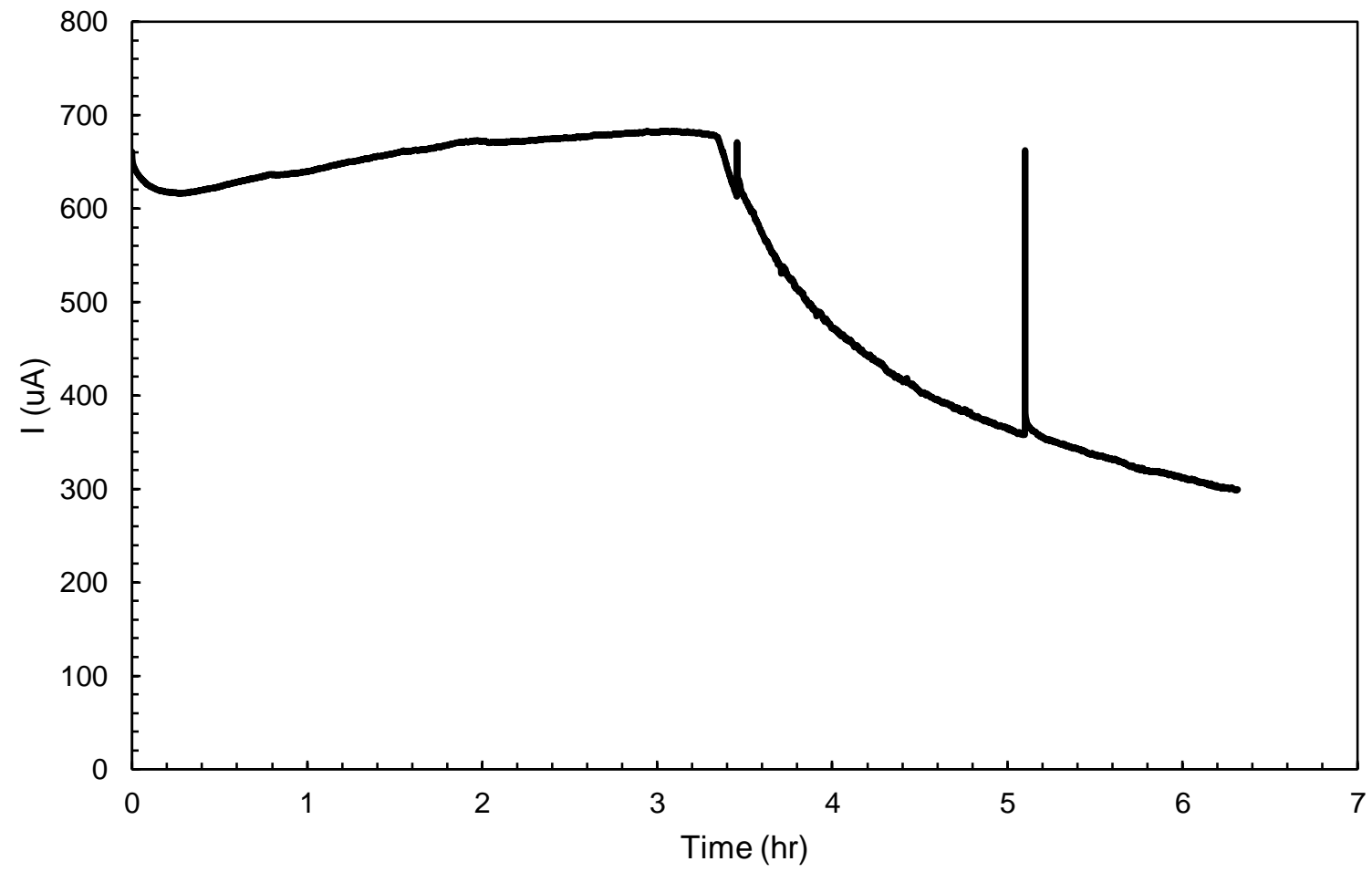

Figure S5. Current vs time plot for the bulk electrocatalytic oxidation of isopropanol to acetone under unmediated conditions (Run \#2) 


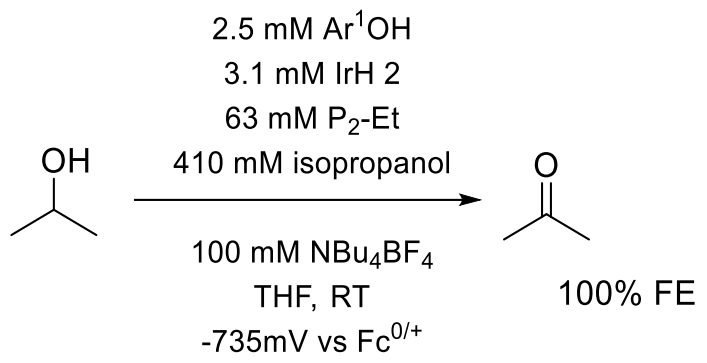

Phenoxyl-mediated Electrocatalytic Oxidation of Isopropanol with IrH 2 and $\mathbf{A r}^{1} \mathbf{O H}$ (Run \#1). The working compartment of the divided glass $\mathrm{H}$-cell was charged with $4.5 \mathrm{~mL}$ of $2.5 \mathrm{mM} \mathrm{Ar} \mathbf{A r}^{1} \mathbf{O H}, 3.1 \mathrm{mM}$ IrH 2, $63 \mathrm{mM} \mathrm{P}_{2}$-Et phosphazene base, $0.41 \mathrm{M}$ isopropanol, and $100 \mathrm{mM} \mathrm{NBu}_{4} \mathrm{BF}_{4}$ in THF. The counter compartment was filled with $4.5 \mathrm{~mL}$ of $63 \mathrm{mM} \mathrm{P}_{2}$-Et phosphazene base, $0.41 \mathrm{M}$ isopropanol, and 100 $\mathrm{mM} \mathrm{NBu}_{4} \mathrm{BF}_{4}$ in THF. The surface areas of the RVC working and counter electrodes were $19.2 \mathrm{~cm}^{2}$ and $22.4 \mathrm{~cm}^{2}$, respectively. The potential of the cell was set at $-735 \mathrm{mV} \mathrm{vs} \mathrm{Fc}^{0 /+}$, the compartments were sealed with septa, and the reaction was stirred at ambient temperature. Following the conclusion of the electrolysis after $6.95 \mathrm{hr}, 900 \mu \mathrm{L}$ of the working compartment solution was combined with $100 \mu \mathrm{L}$ of a $100 \mathrm{mM}$ solution of 1,3,5-trimethoxybenzene in $\mathrm{C}_{6} \mathrm{D}_{6}$ as internal standard. Product conversion was quantified with ${ }^{1} \mathrm{H}$ NMR spectroscopy with suppression of solvent signals. Comparison of the acetone methyl peak to the internal standard aryl peak indicates $0.111 \mathrm{mmol}$ of acetone in the working compartment $\left(\mathrm{TON}=7.9\right.$ with respect to $\mathbf{2}$ and 10.0 with respect to $\left.\mathbf{A} \mathbf{r}^{\mathbf{1}} \mathbf{O H}\right)$. Integration of the current vs time showed $22.43 \mathrm{C}$ of charge were passed, which corresponds to $0.111 \mathrm{mmol}$ expected acetone and a Faradaic Efficiency of $100 \% \pm 10 \%$.

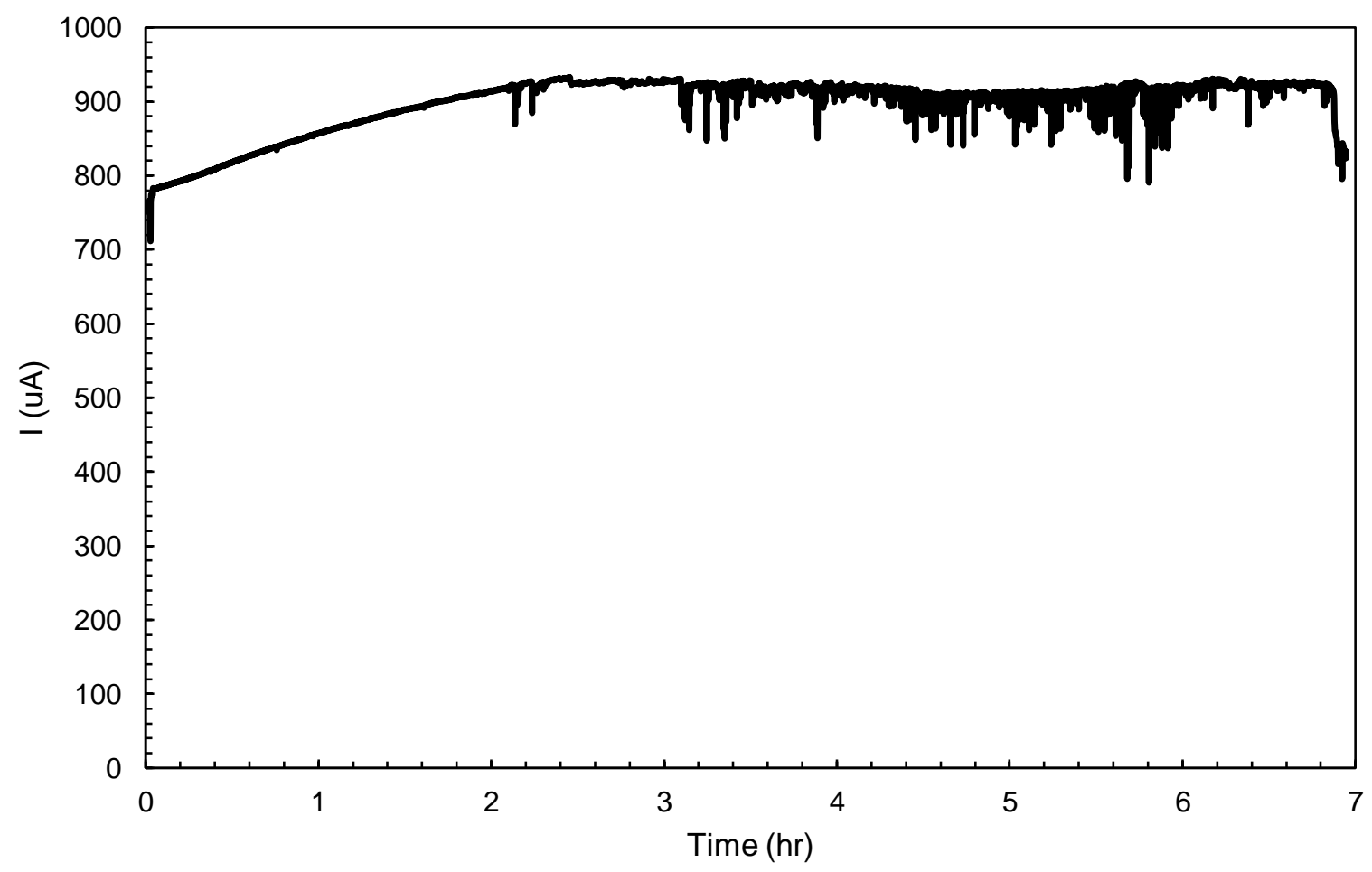

Figure S6. Current vs time plot for the bulk electrocatalytic oxidation of isopropanol to acetone under phenoxyl-mediated conditions (Run \#1) 


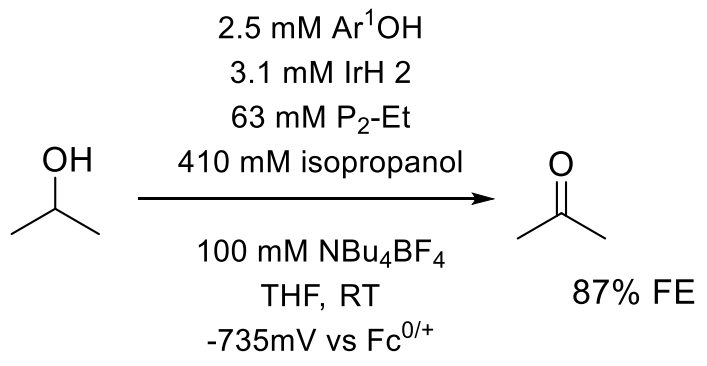

Phenoxyl-mediated Electrocatalytic Oxidation of Isopropanol with IrH 2 and $\mathbf{A r}^{1} \mathrm{OH}$ (Run \#2). The

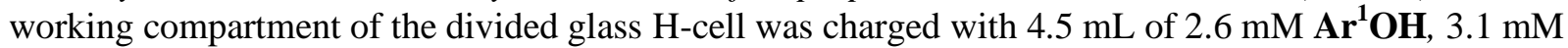
IrH 2, $63 \mathrm{mM} \mathrm{P}_{2}$-Et phosphazene base, $0.41 \mathrm{M}$ isopropanol, and $100 \mathrm{mM} \mathrm{NBu}_{4} \mathrm{BF}_{4}$ in THF. The counter compartment was filled with $4.5 \mathrm{~mL}$ of $63 \mathrm{mM} \mathrm{P}_{2}$-Et phosphazene base, $0.41 \mathrm{M}$ isopropanol, and 100 $\mathrm{mM} \mathrm{NBu}_{4} \mathrm{BF}_{4}$ in THF. The surface areas of the RVC working and counter electrodes were $20.2 \mathrm{~cm}^{2}$ and $24.0 \mathrm{~cm}^{2}$, respectively. The potential of the cell was set at $-735 \mathrm{mV} \mathrm{vs} \mathrm{Fc}^{0 /+}$, the compartments were sealed with septa, and the reaction was stirred at ambient temperature. Following the conclusion of the electrolysis after $7.94 \mathrm{hr}, 900 \mu \mathrm{L}$ of the working compartment solution was combined with $100 \mu \mathrm{L}$ of a $100 \mathrm{mM}$ solution of 1,3,5-trimethoxybenzene in $\mathrm{C}_{6} \mathrm{D}_{6}$ as internal standard. Product conversion was quantified with ${ }^{1} \mathrm{H}$ NMR spectroscopy with suppression of solvent signals. Comparison of the acetone methyl peak to the internal standard aryl peak indicates $0.112 \mathrm{mmol}$ real acetone in the working compartment $\left(\mathrm{TON}=7.9\right.$ with respect to $\mathbf{2}$ and $\mathrm{TON}=9.6$ with respect to $\left.\mathbf{A r}^{\mathbf{1}} \mathbf{O H}\right)$. Integration of the current vs time showed $25.72 \mathrm{C}$ of charge were passed, which corresponds to $0.133 \mathrm{mmol}$ expected acetone and a Faradaic Efficiency of $87 \% \pm 10 \%$.

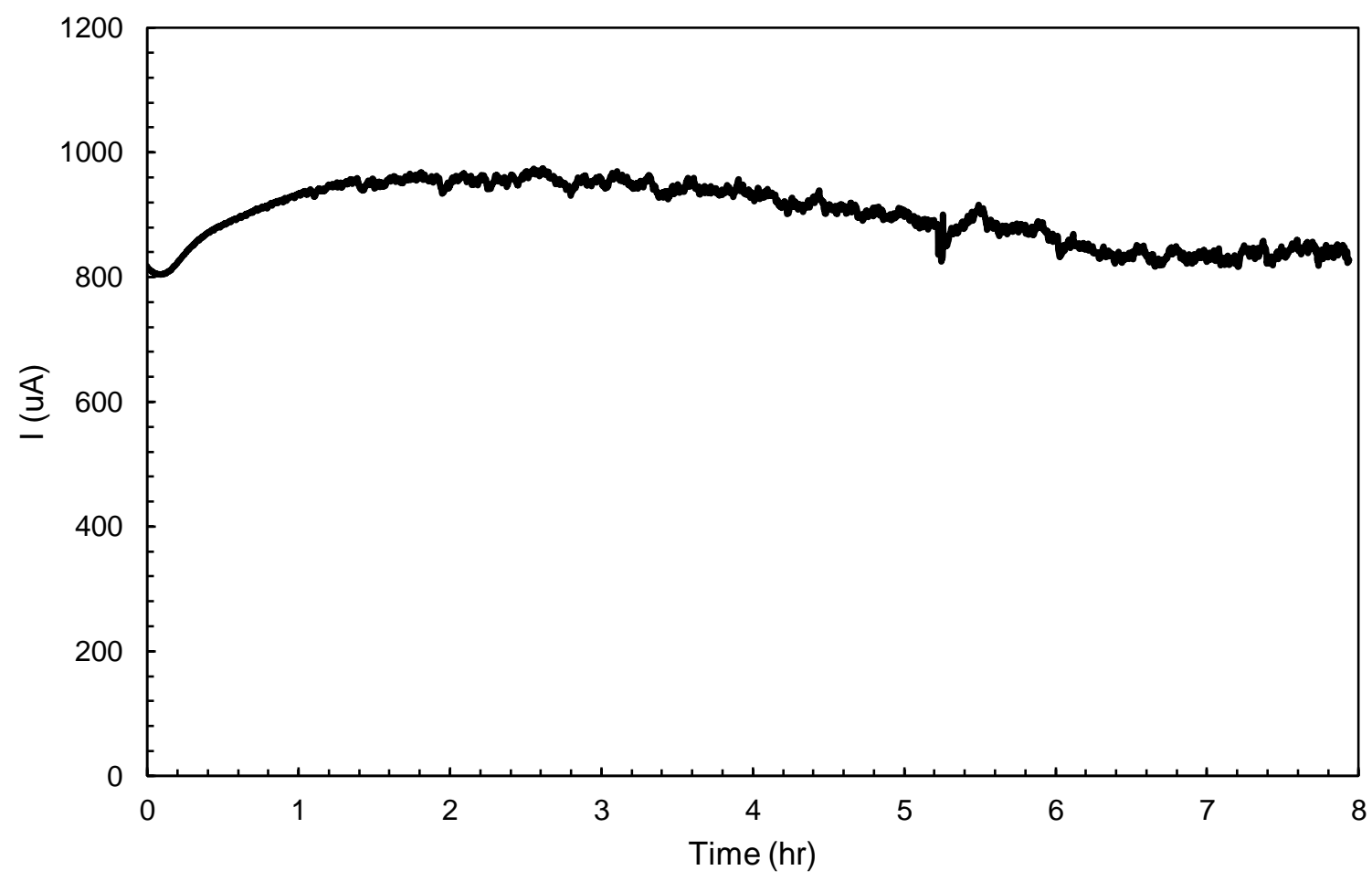

Figure S7. Current vs time plot for the bulk electrocatalytic oxidation of isopropanol to acetone under phenoxyl-mediated conditions (Run \#2) 


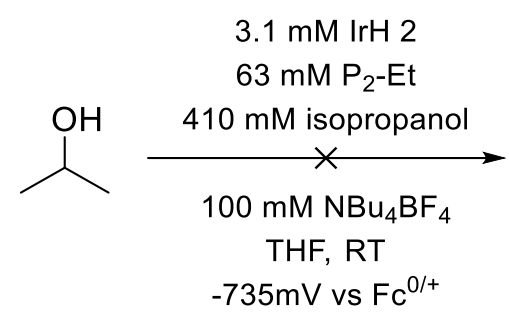

Control electrolysis of unmediated catalytic solution conditions at low potential. The working compartment of the divided glass $\mathrm{H}$-cell was charged with $4.5 \mathrm{~mL}$ of $3.1 \mathrm{mM} \operatorname{IrN~1,~} 63 \mathrm{mM} \mathrm{P}_{2}$-Et phosphazene base, $0.41 \mathrm{M}$ isopropanol, and $100 \mathrm{mM} \mathrm{NBu}_{4} \mathrm{BF}_{4}$ in THF. The counter compartment was filled with $4.5 \mathrm{~mL}$ of $63 \mathrm{mM} \mathrm{P}_{2}$-Et phosphazene base, $0.41 \mathrm{M}$ isopropanol, and $100 \mathrm{mM} \mathrm{NBu}_{4} \mathrm{BF}_{4}$ in THF. The surface areas of the RVC working and counter electrodes were $15.6 \mathrm{~cm}^{2}$ and $22.4 \mathrm{~cm}^{2}$, respectively. The potential of the cell was set at $-735 \mathrm{mV} \mathrm{vs} \mathrm{Fc}^{0 /+}$, the compartments were sealed with septa, and the reaction was stirred at ambient temperature. Following the conclusion of the electrolysis after $7.50 \mathrm{hr}, 900 \mu \mathrm{L}$ of the working compartment solution was combined with $100 \mu \mathrm{L}$ of a $100 \mathrm{mM}$ solution of 1,3,5-trimethoxybenzene in $\mathrm{C}_{6} \mathrm{D}_{6}$ as internal standard. Product conversion was quantified with ${ }^{1} \mathrm{H}$ NMR spectroscopy with suppression of solvent signals. Comparison of the acetone methyl peak to the internal standard aryl peak indicates $0.011 \mathrm{mmol}$ real acetone in the working compartment (TON $=0.8$ ). Integration of the current vs time showed only $3.55 \mathrm{C}$ of charge were passed.

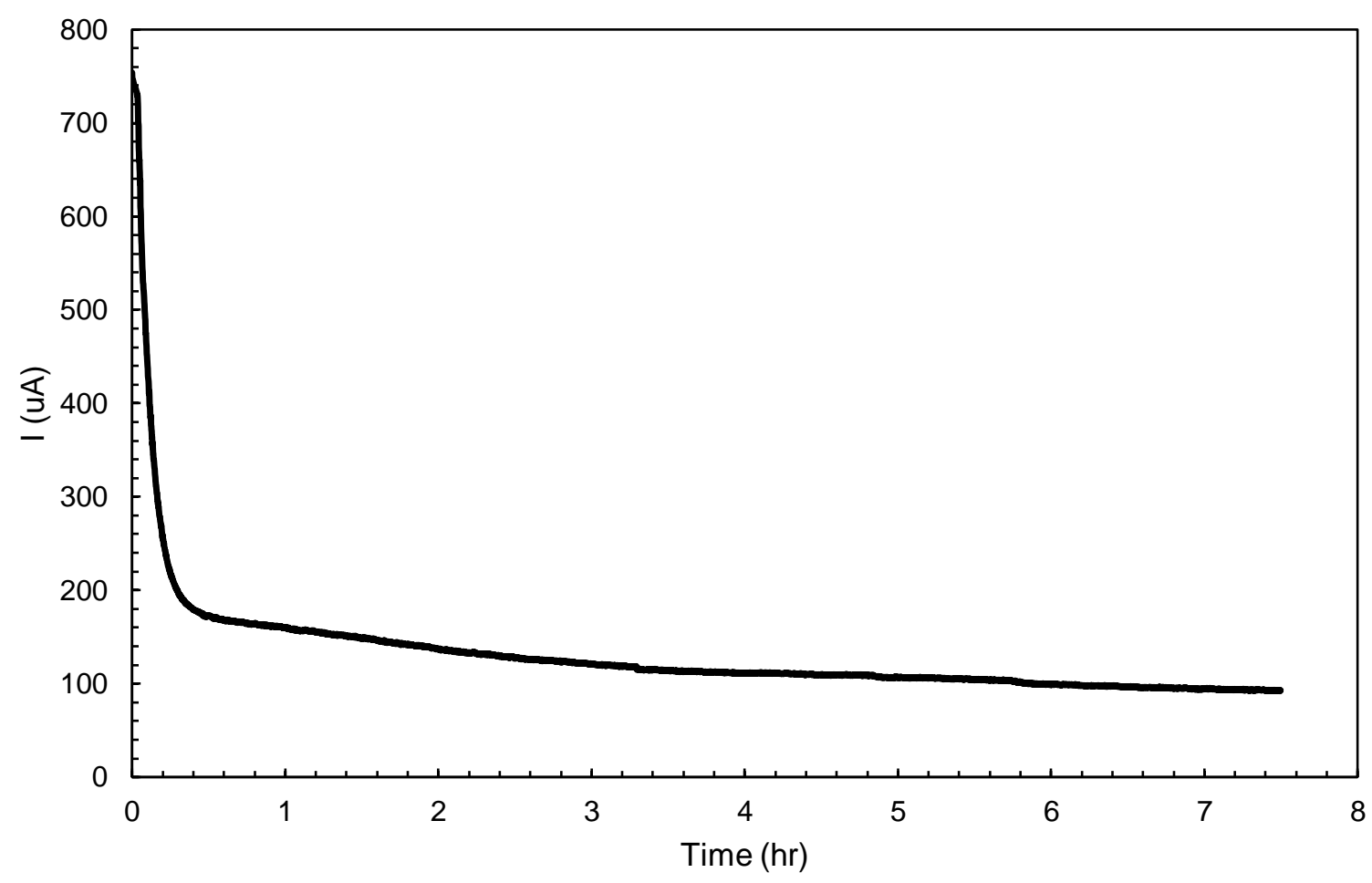

Figure S8. Current vs time plot for the control electrolysis of unmediated catalytic solution conditions at low potential 


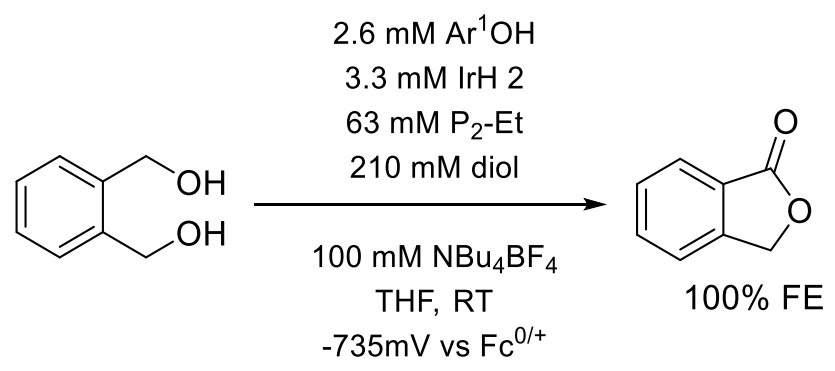

Phenoxyl-mediated Electrocatalytic Oxidation of 1,2-benzenedimethanol with IrH 2 and $\mathbf{A r}^{1} \mathbf{O H}$. The

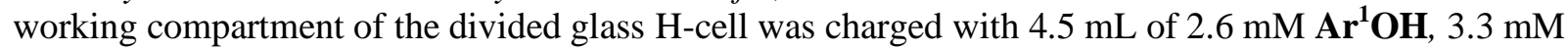
IrH 2, $63 \mathrm{mM} \mathrm{P}_{2}$-Et phosphazene base, $0.21 \mathrm{M} \mathrm{1,2-benzenedimethanol,} \mathrm{and} 100 \mathrm{mM} \mathrm{NBu}_{4} \mathrm{BF}_{4}$ in THF. The counter compartment was filled with $4.5 \mathrm{~mL}$ of $63 \mathrm{mM} \mathrm{P}_{2}$-Et phosphazene base, $0.21 \mathrm{M} \mathrm{1,2-}$ benzenedimethanol, and $100 \mathrm{mM} \mathrm{NBu}_{4} \mathrm{BF}_{4}$ in THF. The surface areas of the RVC working and counter electrodes were $20.8 \mathrm{~cm}^{2}$ and $23.2 \mathrm{~cm}^{-1}$, respectively. The potential of the cell was set at $-735 \mathrm{mV} \mathrm{vs} \mathrm{Fc}^{0 /+}$, the compartments were sealed with septa, and the reaction was stirred at ambient temperature. Following the conclusion of the electrolysis after $5.19 \mathrm{hr}, 900 \mu \mathrm{L}$ of the working compartment solution was combined with $100 \mu \mathrm{L}$ of a $100 \mathrm{mM}$ solution of 1,3,5-trimethoxybenzene in $\mathrm{C}_{6} \mathrm{D}_{6}$ as internal standard. Product conversion was quantified with ${ }^{1} \mathrm{H}$ NMR spectroscopy with suppression of solvent signals. Comparison of the phthalide benzylic peak to the internal standard aryl peak indicates $0.082 \mathrm{mmol}$ real phthalide in the working compartment $(\mathrm{TON}=5.6$ with respect to 1 and $\mathrm{TON}=7.1$ with respect to $\left.\mathbf{A r}^{1} \mathbf{O H}\right)$. Integration of the current vs time showed $30.35 \mathrm{C}$ of charge were passed, which corresponds to $0.076 \mathrm{mmol}$ expected phthalide and a Faradaic Efficiency of $100 \% \pm 10 \%$.

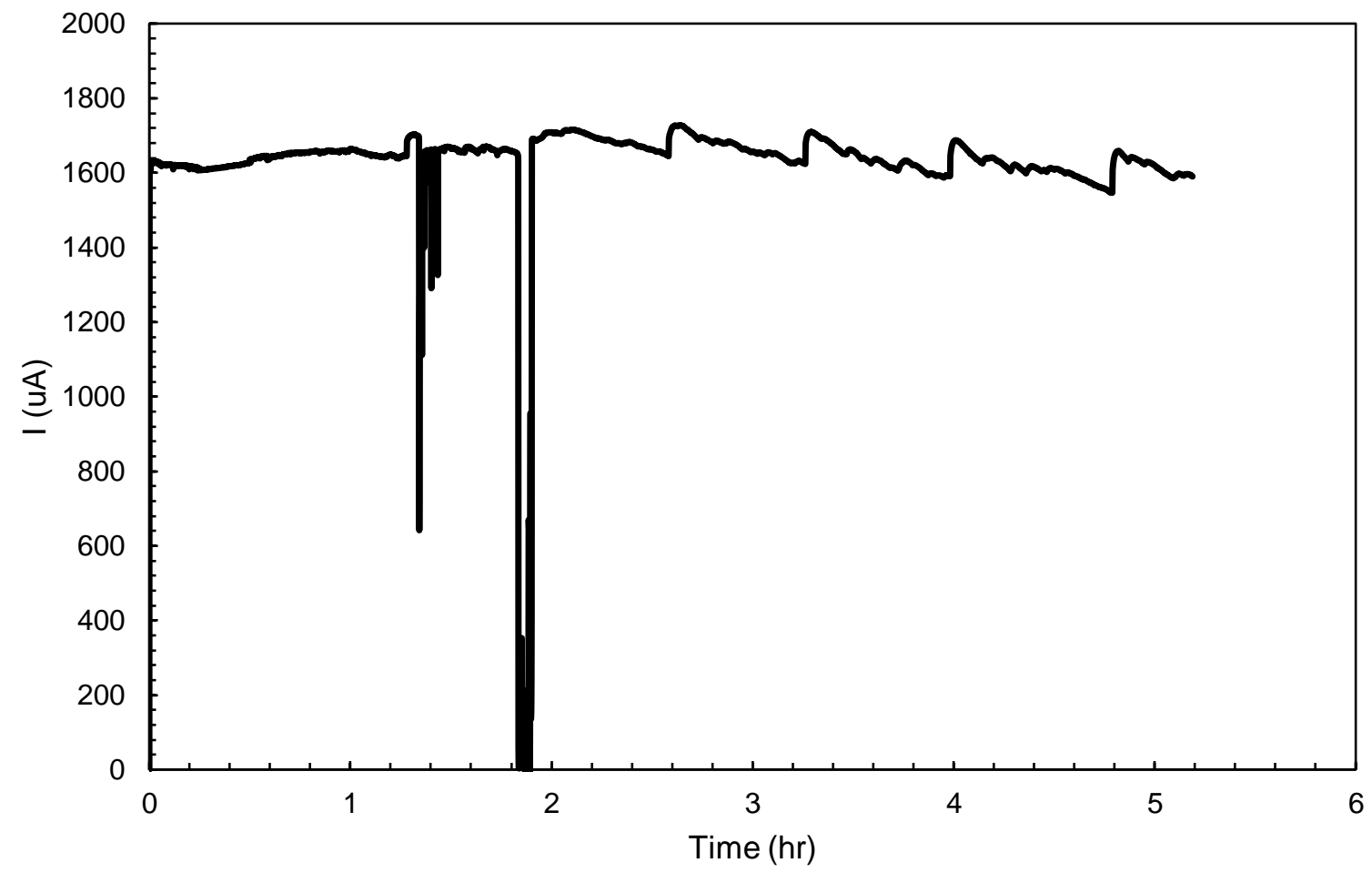

Figure S9. Current vs time plot for the bulk electrocatalytic oxidation of 1,2-benzenedimethanol to phthalide under phenoxyl-mediated conditions 


\section{Non-electrochemical Reactions}

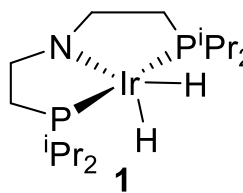

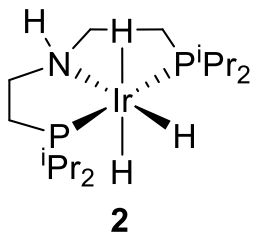

Transfer hydrogenation equilibrium of IrN 1 and isopropanol. In a nitrogen-filled glovebox, a 2-dram vial was charged with $\operatorname{IrN} 1(4.4 \mathrm{mg}, 8.8 \mu \mathrm{mol})$. The catalyst was dissolved in toluene- $d_{8}(550 \mu \mathrm{L})$, and isopropanol ( $5 \mu \mathrm{L}, 65 \mu \mathrm{mol})$ was added to the solution. The entire solution was transferred to a gas-tight Jyoung NMR tube. ${ }^{1} \mathrm{H}$ and ${ }^{31} \mathrm{P}$ NMR spectra were acquired approximately 10 minutes after the addition of the isopropanol. Analysis by NMR revealed that IrN 1 was consumed to generate the Ir-H 2. $\left({ }^{1} \mathrm{H}\right.$ NMR (400 MHz, toluene- $\left.d_{8}\right) \delta-22.18(\mathrm{~m}, 2 \mathrm{H}, \mathrm{IrH}) .{ }^{31} \mathrm{P}$ NMR $\left(400 \mathrm{MHz}\right.$, toluene- $\left.d_{8}\right) \delta 80.54(\mathrm{~s}, 2 \mathrm{P})$.) to IrH $2\left({ }^{1} \mathrm{H}\right.$ NMR $\left(400 \mathrm{MHz}\right.$, toluene- $\left.d_{8}\right) \delta-11.65\left(\mathrm{td}, J_{P H}=16.5, J_{H H}=5.3 \mathrm{~Hz}, 1 \mathrm{H}, \mathrm{IrH}\right),-12.41\left(\mathrm{td}, J_{P H}=17.6, J_{H H}=5.3 \mathrm{~Hz}\right.$ $5.1 \mathrm{~Hz}, 1 \mathrm{H}, \mathrm{IrH}),-22.33(\mathrm{~m}, 1 \mathrm{H}, \mathrm{IrH}) .{ }^{31} \mathrm{P}$ NMR $\left(400 \mathrm{MHz}\right.$, toluene- $\left.d_{8}\right) \delta 62.39(\mathrm{~s}, 2 \mathrm{P})$.)

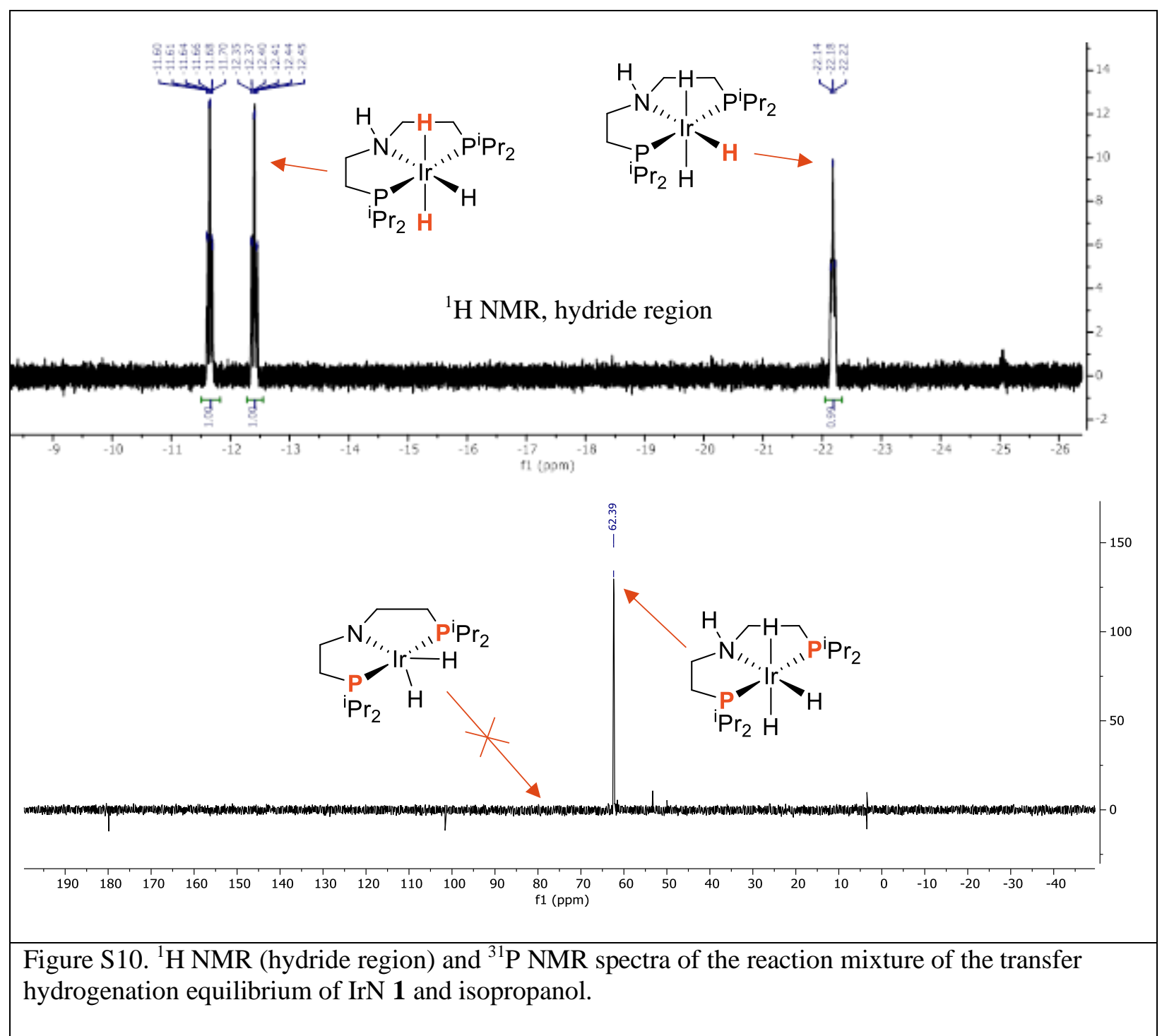




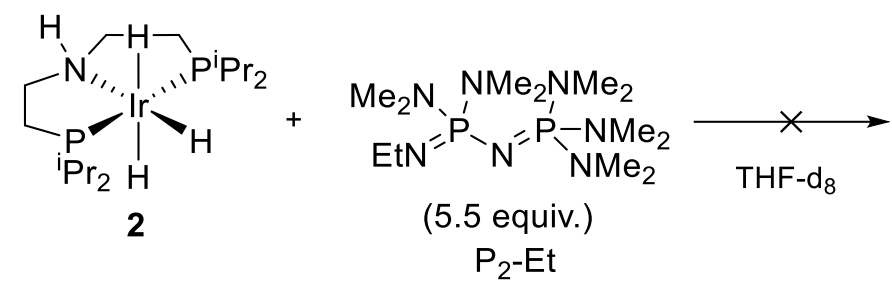

Acid-Base equilibrium of IrH 2 and phosphazene base $P_{2}$-Et. In a nitrogen-filled glovebox, a gas-tight JYoung NMR tube was charged with IrN $1(10.2 \mathrm{mg}, 20 \mu \mathrm{mol})$, THF $(1 \mathrm{~mL})$, and isopropanol $(100 \mu \mathrm{L}, 1.3$ mmol). The J-Young NMR tube was connected to a Schlenk manifold, and the solvents were removed under high vacuum to afford a light-orange solid powder. The tube was returned to the glovebox, and the solid was redissolved in THF- $d_{8}(0.5 \mathrm{~mL}) .{ }^{1} \mathrm{H}$ and ${ }^{31} \mathrm{P}$ NMR spectroscopy confirmed quantitative conversion of IrN 1 to IrH 2. Phosphazene base $\mathrm{P}_{2}$-Et ( $\left.37 \mu \mathrm{L}, 110 \mu \mathrm{mol}\right)$ was added to the solution of IrH $2 .{ }^{1} \mathrm{H}$ and ${ }^{31} \mathrm{P}$ NMR spectroscopy show only minor changes in the ${ }^{1} \mathrm{H}$ chemical shifts of the iridium hydrides $(\delta-12.07$ $(1 \mathrm{H}, \mathrm{IrH}),-12.59(1 \mathrm{H}, \mathrm{IrH}),-22.58(1 \mathrm{H}, \mathrm{IrH}))$ and amino proton $(\delta-4.80(1 \mathrm{H}, \mathrm{NH}))$ and in the ${ }^{31} \mathrm{P}$ phosphine $(\delta 64.91(2 \mathrm{P}))$ chemical shifts. This suggests that IrH $\mathbf{2}$ is an extremely weak acid and that the dominant resting state of the iridium catalyst in bulk solution in the presence of isopropanol and $\mathrm{P}_{2}$-Et is IrH 2 and not a conjugate base thereof nor IrN 1.

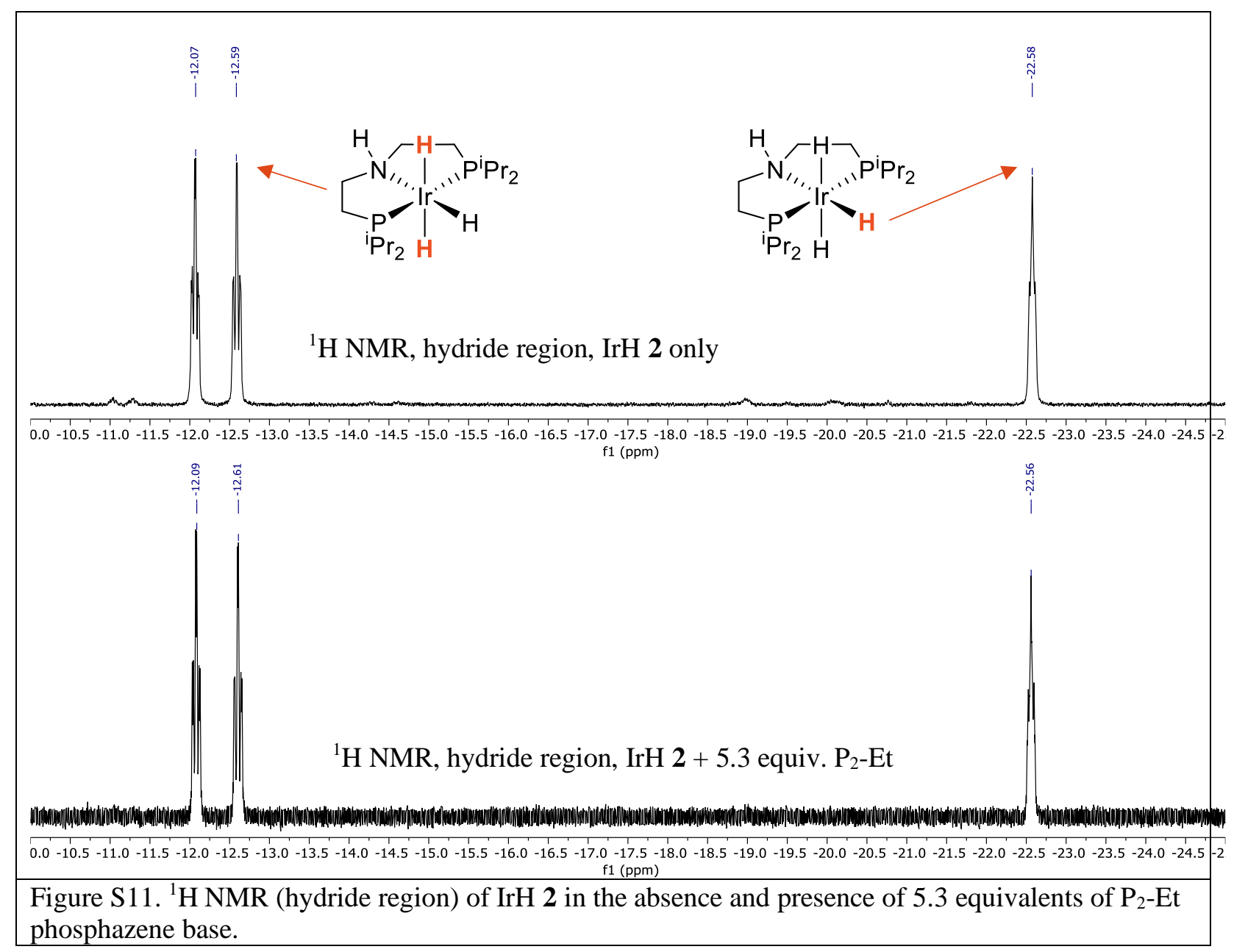




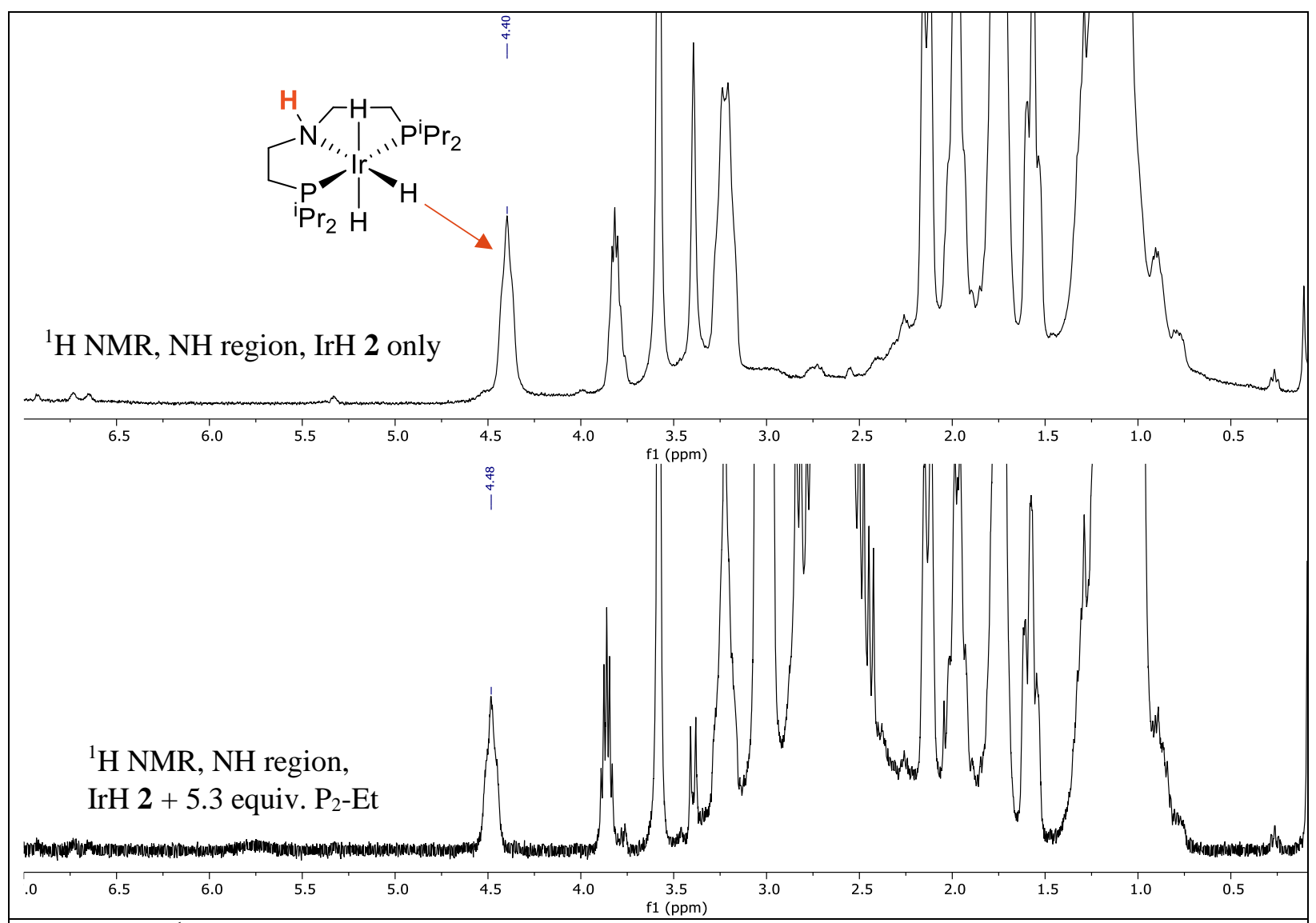

Figure S12. ${ }^{1} \mathrm{H}$ NMR (N-H region) of IrH 2 in the absence and presence of 5.3 equivalents of $\mathrm{P}_{2}$-Et phosphazene base. 


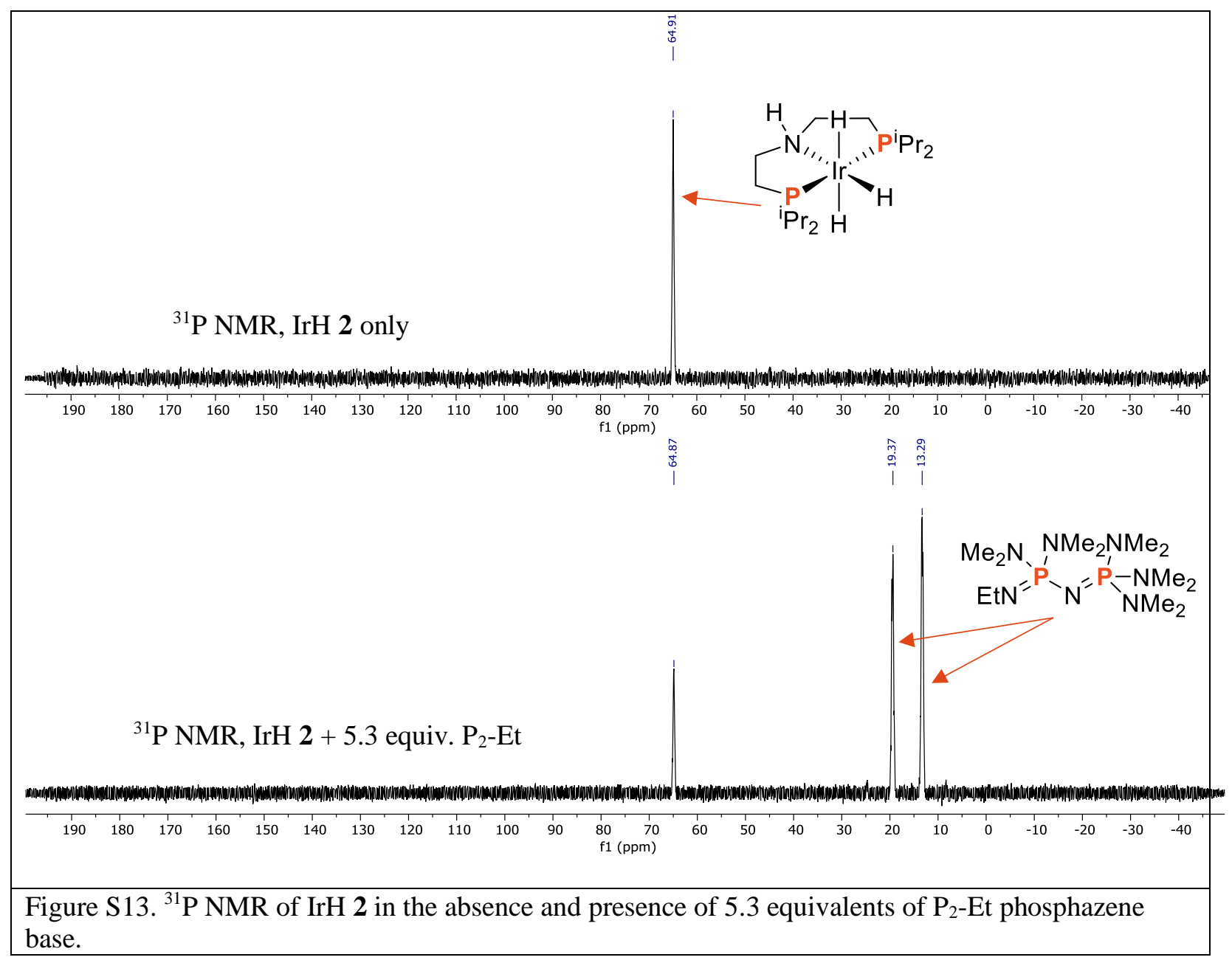




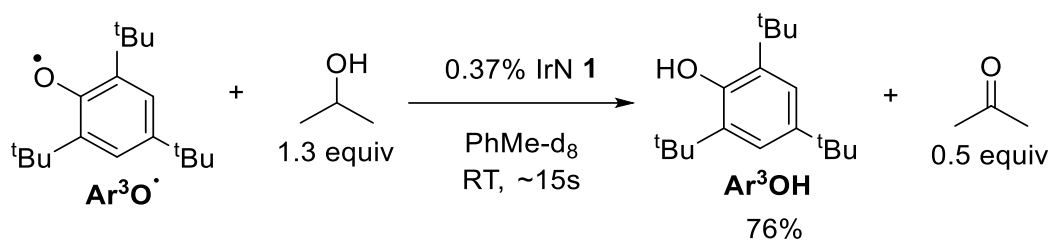

Catalytic dehydrogenation of isopropanol with a persistent phenoxyl terminal oxidant. In a nitrogen-filled glovebox, a 2-dram vial equipped with a magnetic stir bar was charged with 2,4,6-tri-tert-butylphenoxyl $\mathbf{A r}^{3} \mathbf{O} \cdot(70.5 \mathrm{mg}, 0.270 \mathrm{mmol})$, toluene- $d_{8}(500 \mu \mathrm{l})$, and 1,3,5-trimethoxybenzene (11.1 $\left.\mathrm{mg}, 0.066 \mathrm{mmol}\right)$ as an internal standard. In a second 2-dram vial, $\operatorname{IrN} 1(1.8 \mathrm{mg}, 3.6 \mu \mathrm{mol})$ was dissolved in toluene- $d_{8}(200$ $\mu \mathrm{l})$ and isopropanol $(100 \mu 1,1.31 \mathrm{mmol}) .80 \mu \mathrm{l}$ of this IrN 1 solution was added to the rapidly stirred solution of $\mathbf{A r}^{3} \mathbf{O} \cdot$ and 1,3,5-trimethoxybenzene at ambient temperature. After about 15 seconds, the dark blue color of $\mathbf{A r}^{3} \mathbf{O} \cdot$ disappeared to give a light yellow solution. The entire reaction mixture was then transferred to a gas-tight J-young NMR tube. Subsequent analysis with ${ }^{1} \mathrm{H}$ NMR spectroscopy showed $76 \%$ conversion to the parent phenol product $\mathbf{A r}^{3} \mathbf{O H}\left({ }^{1} \mathrm{H}\right.$ NMR $\left(400 \mathrm{MHz}\right.$, toluene- $\left.d_{8}\right) \delta 1.301(\mathrm{~s}, 9 \mathrm{H}, t \mathrm{Bu}) \delta 1.301(\mathrm{~s}, 18 \mathrm{H}$, $2 t \mathrm{Bu}) \delta 4.859(\mathrm{~s}, 1 \mathrm{H}, \mathrm{OH}) \delta 7.286(\mathrm{~s}, 2 \mathrm{H}, \mathrm{ArH}))$ based on the internal standard 1,3,5-trimethoxybenzene $\left({ }^{1} \mathrm{H}\right.$ NMR $\left(400 \mathrm{MHz}\right.$, toluene- $\left.\left.d_{8}\right) \delta 3.344(\mathrm{~s}, 9 \mathrm{H}, 3 \mathrm{OMe}) \delta 6.095(\mathrm{~s}, 3 \mathrm{H}, 3 \mathrm{ArH})\right)$. The ratio of $\mathbf{A} \mathbf{r}^{3} \mathbf{O H}$ to acetone $\left({ }^{1} \mathrm{H}\right.$ NMR $\left(400 \mathrm{MHz}\right.$, toluene- $\left.\left.d_{8}\right) \delta 1.597(\mathrm{~s}, 6 \mathrm{H}, 2 \mathrm{Me})\right)$ was $2: 1$. Residual isopropanol $\left({ }^{1} \mathrm{H}\right.$ NMR $\left(400 \mathrm{MHz}\right.$, toluene- $\left.\left.d_{8}\right) \delta 1.016(\mathrm{~d}, 6 \mathrm{H}, 2 \mathrm{Me}) \delta 3.749(\mathrm{~m}, 1 \mathrm{H}, \mathrm{CH})\right)$
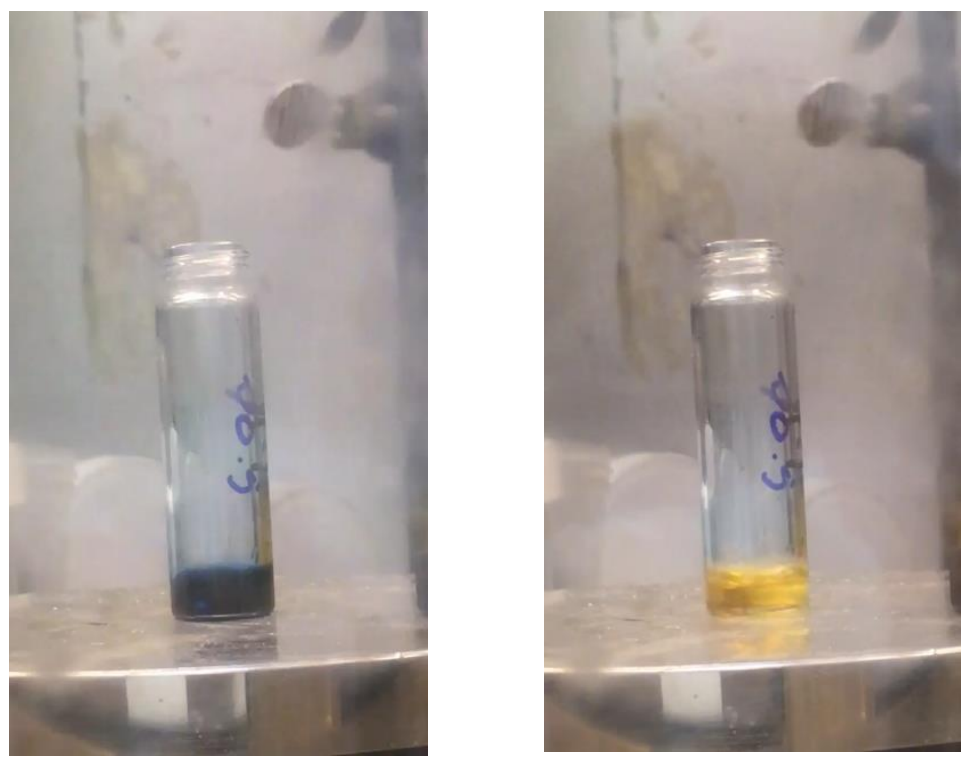

Figure S14. Solution of $\mathbf{A r}^{3} \mathbf{O} \cdot$ prior to the addition of isopropanol and catalyst $\mathbf{1}$ (left) and the reaction mixture about 15 seconds after the addition of isopropanol and catalyst $\mathbf{1}$ (right). 


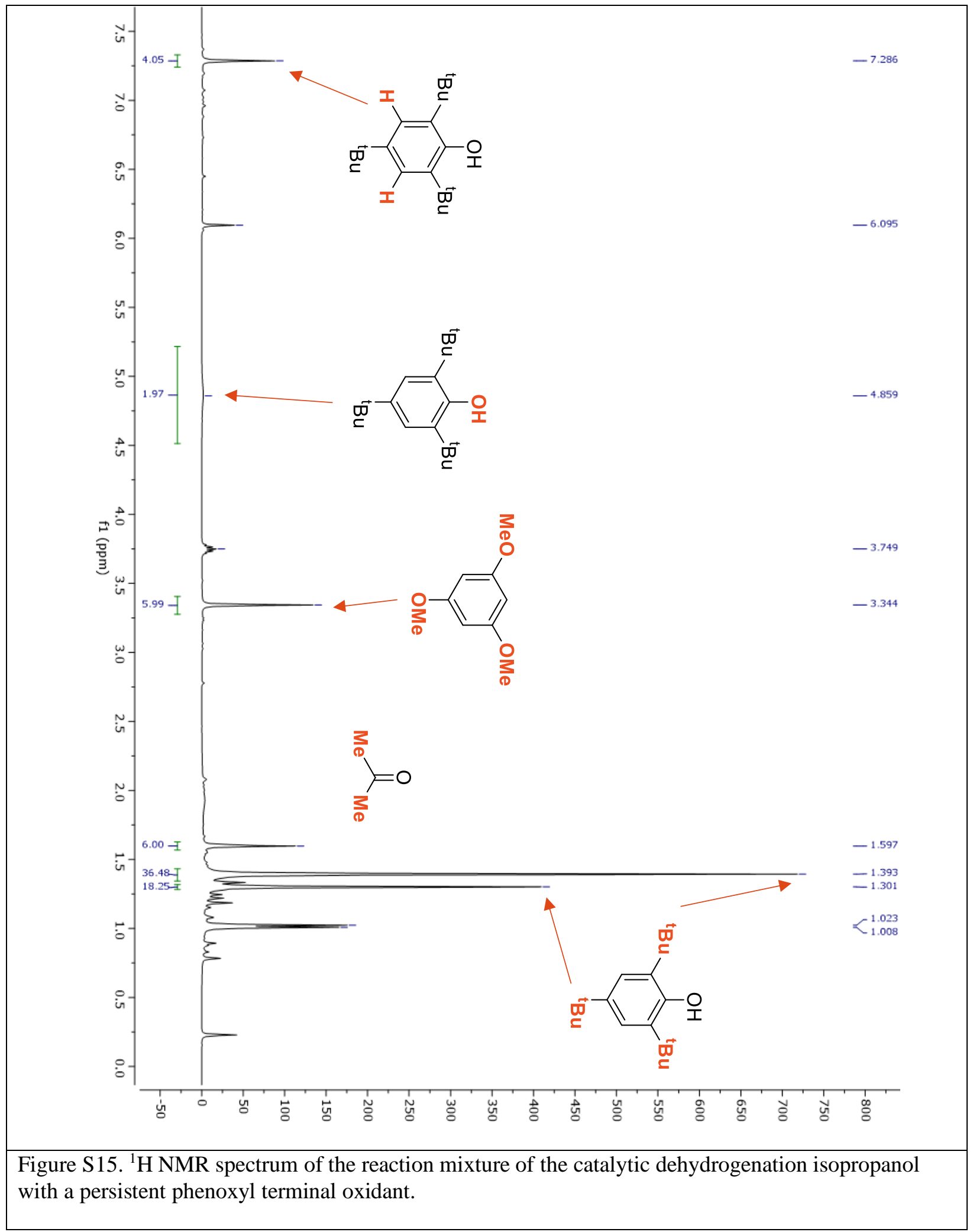




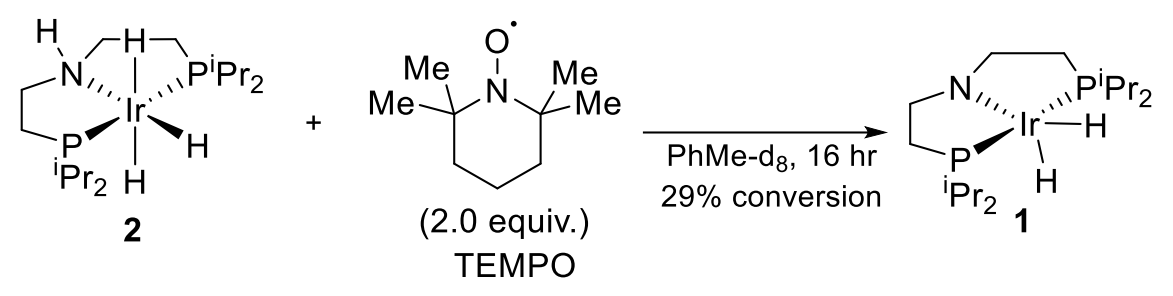

Slow oxidation of IrH 2 to IrN 1 by TEMPO. In a nitrogen-filled glovebox, a gas-tight J-Young NMR tube was charged with IrN $1(5.4 \mathrm{mg}, 11 \mu \mathrm{mol})$, THF $(0.9 \mathrm{~mL})$, and isopropanol $(150 \mu \mathrm{L}, 2.0 \mathrm{mmol})$. The JYoung NMR tube was connected to a Schlenk manifold, and the solvents were removed under high vacuum to afford a light-orange solid powder. The tube was returned to the glovebox, and the solid was redissolved in toluene- $d_{8}(0.5 \mathrm{~mL}) .{ }^{1} \mathrm{H}$ and ${ }^{31} \mathrm{P}$ NMR spectroscopy confirmed quantitative conversion of IrN 1 to $\operatorname{IrH} 2$. The tube was returned to the glovebox again, and a solution of (2,2,6,6-tetramethylpiperidin-1-yl)oxyl TEMPO in toluene- $d_{8}(77 \mathrm{uL}, 0.28 \mathrm{M}, 22 \mu \mathrm{mol})$ was added to the J-Young tube. The tube was inverted several times to ensure complete mixing, and ${ }^{1} \mathrm{H}$ and ${ }^{31} \mathrm{P}$ NMR spectra were recorded about 20 minutes and 16 hours after the addition of TEMPO. The earlier time point shows only the hydride $\left({ }^{1} \mathrm{H} \mathrm{NMR}(400 \mathrm{MHz}\right.$, toluene- $\left.d_{8}\right) \delta-11.65\left(\mathrm{td}, J_{P H}=16.5, J_{H H}=5.3 \mathrm{~Hz}, 1 \mathrm{H}, \mathrm{IrH}\right),-12.34\left(\mathrm{td}, J_{P H}=17.6, J_{H H}=5.3 \mathrm{~Hz} 5.1 \mathrm{~Hz}, 1 \mathrm{H}\right.$, $\mathrm{IrH}),-22.18(\mathrm{~m}, 1 \mathrm{H}, \mathrm{IrH}))$ and phosphorus $\left({ }^{31} \mathrm{P}\right.$ NMR $\left(400 \mathrm{MHz}\right.$, toluene- $\left.\left.d_{8}\right) \delta 62.39(\mathrm{~s}, 2 \mathrm{P})\right)$ signals of the IrH 2 starting material, but the later time point shows the characteristic hydride $\left({ }^{1} \mathrm{H}\right.$ NMR $(400 \mathrm{MHz}$, toluene- $\left.\left.d_{8}\right) \delta-22.34(\mathrm{~s}, 2 \mathrm{H}, \mathrm{IrH})\right)$ and phosphorus $\left({ }^{31} \mathrm{P}\right.$ NMR $\left(400 \mathrm{MHz}\right.$, toluene- $\left.\left.d_{8}\right) \delta 80.57(\mathrm{~s}, 2 \mathrm{P})\right)$ peaks of IrN 1 (29\% conversion) as well as the methyl $\left({ }^{1} \mathrm{H}\right.$ NMR $\left(400 \mathrm{MHz}\right.$, toluene- $\left.\left.d_{8}\right) \delta 1.12(\mathrm{~s}, 12 \mathrm{H}, 4 \mathrm{Me})\right)$ peak of 2,2,6,6-tetramethylpiperidin-1-ol TEMPOH. 


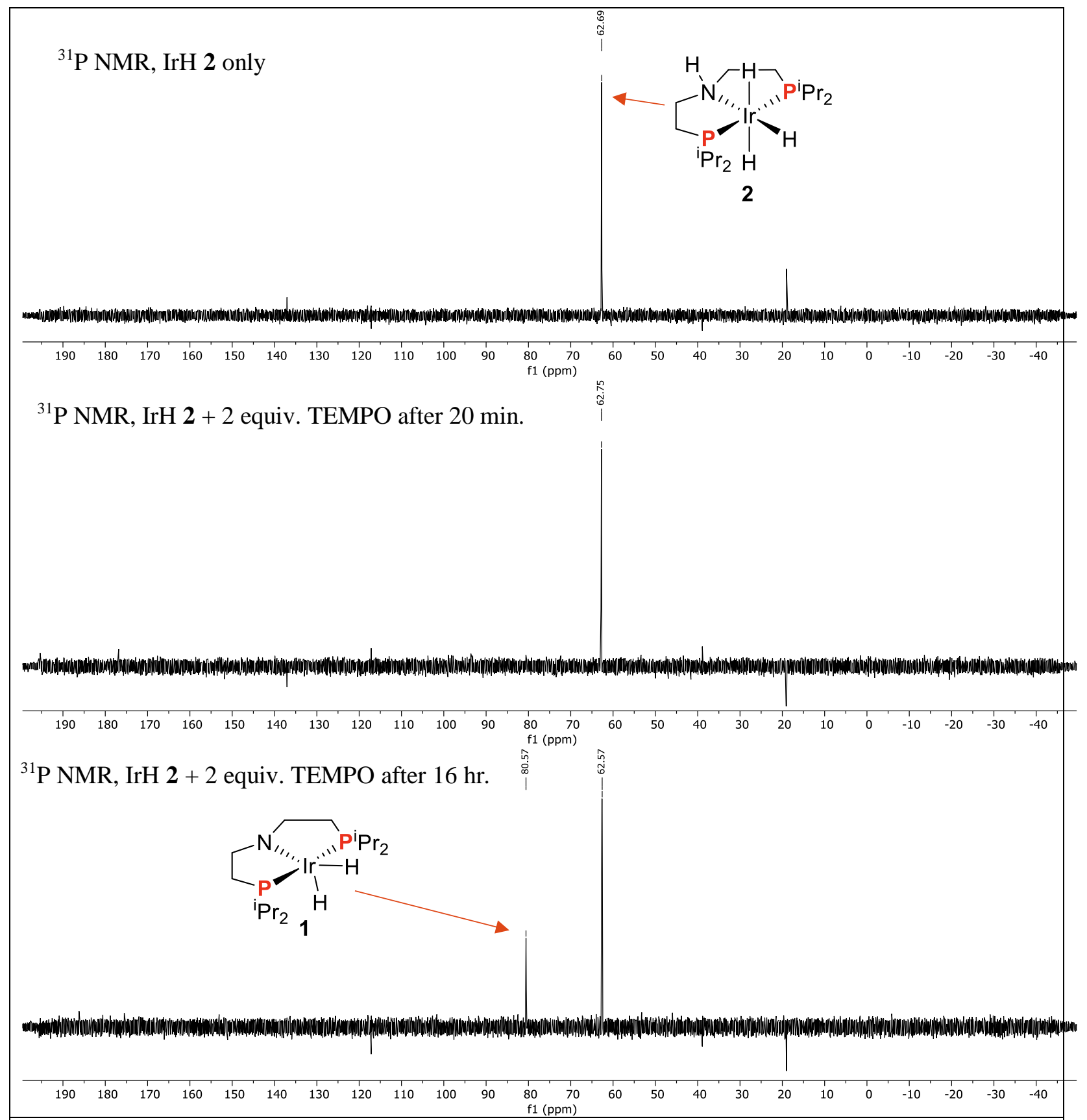

Figure S16. ${ }^{31} \mathrm{P}$ NMR of IrH 2 slow oxidation to IrN 1 by TEMPO. 


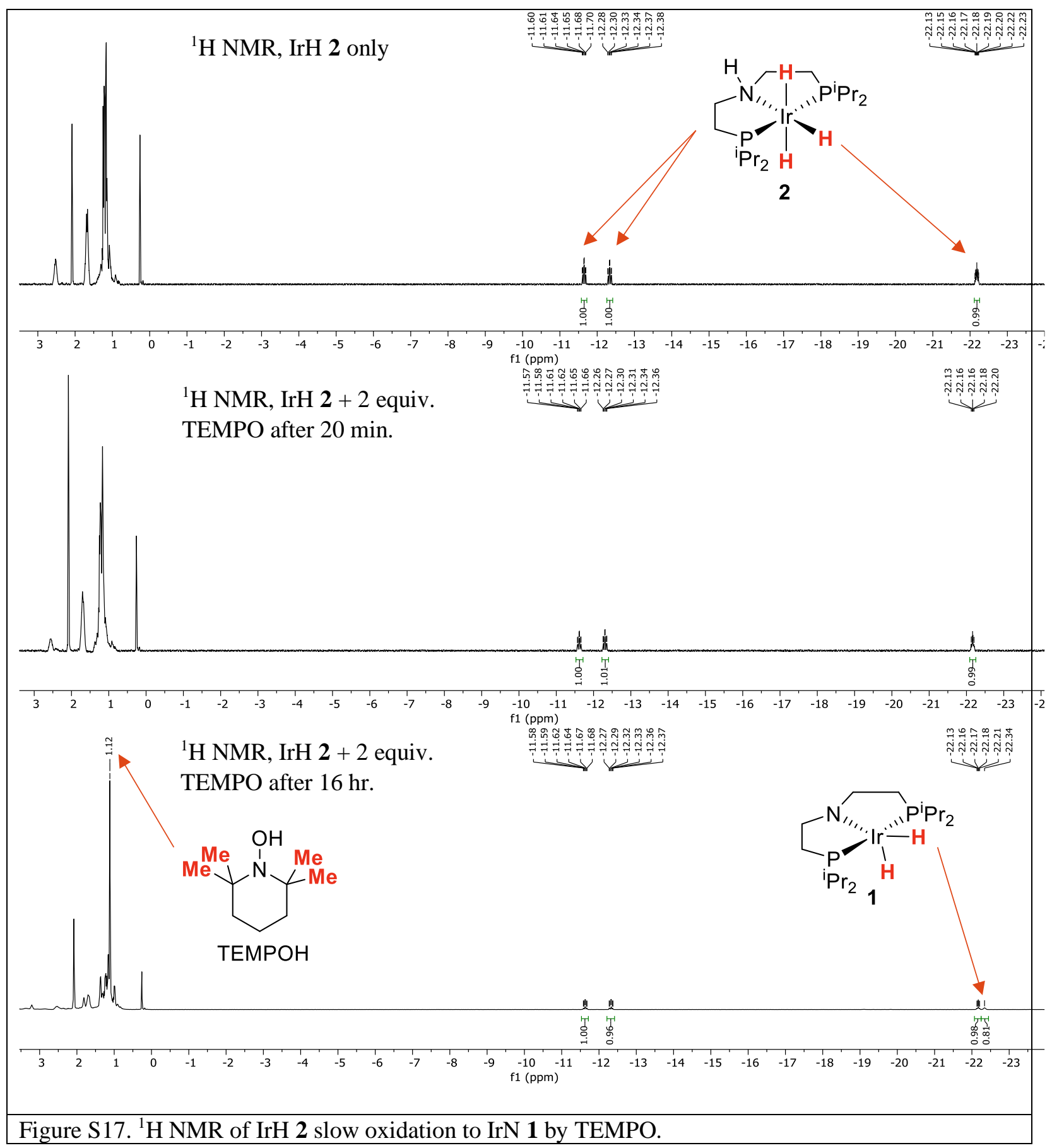




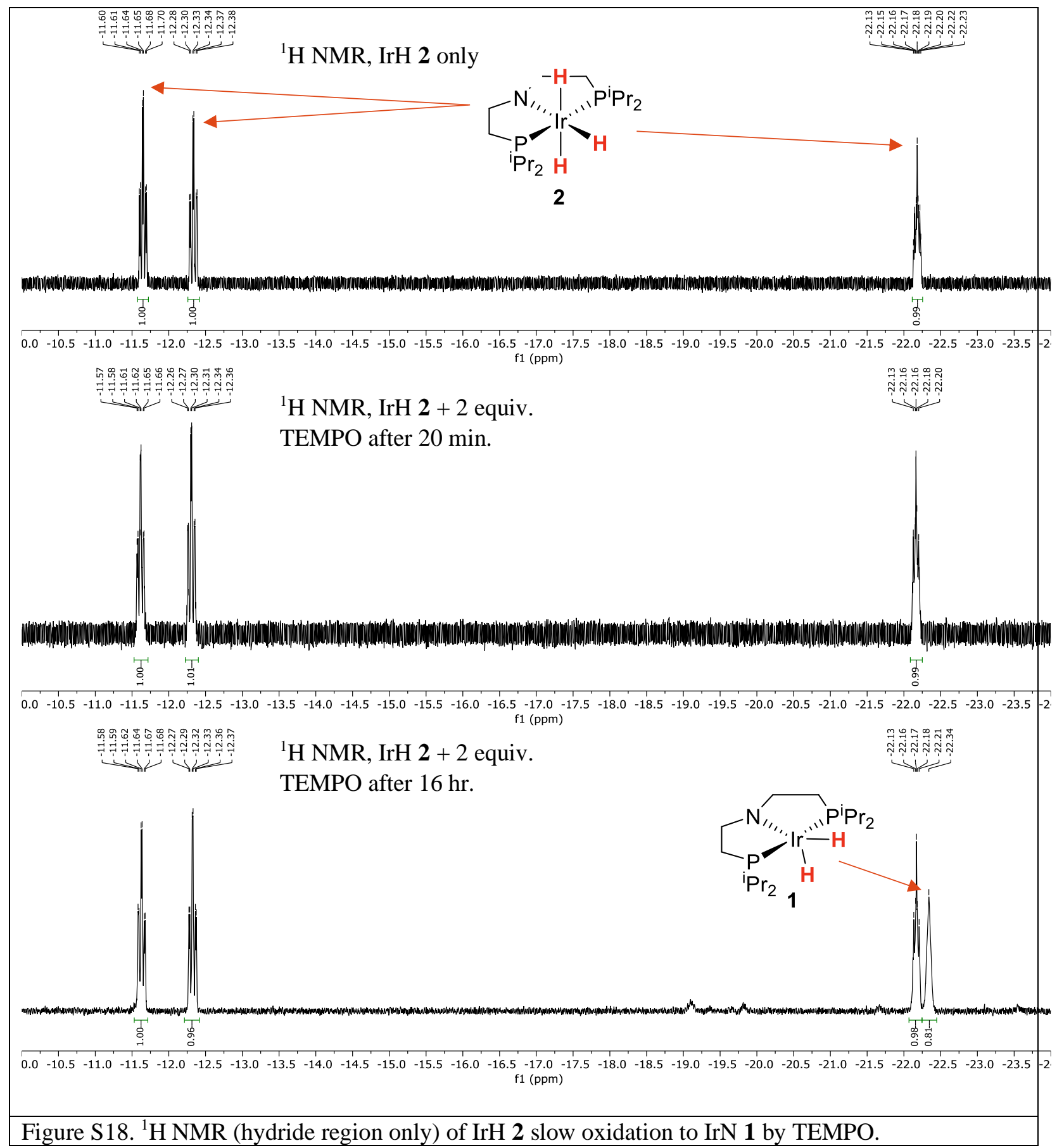




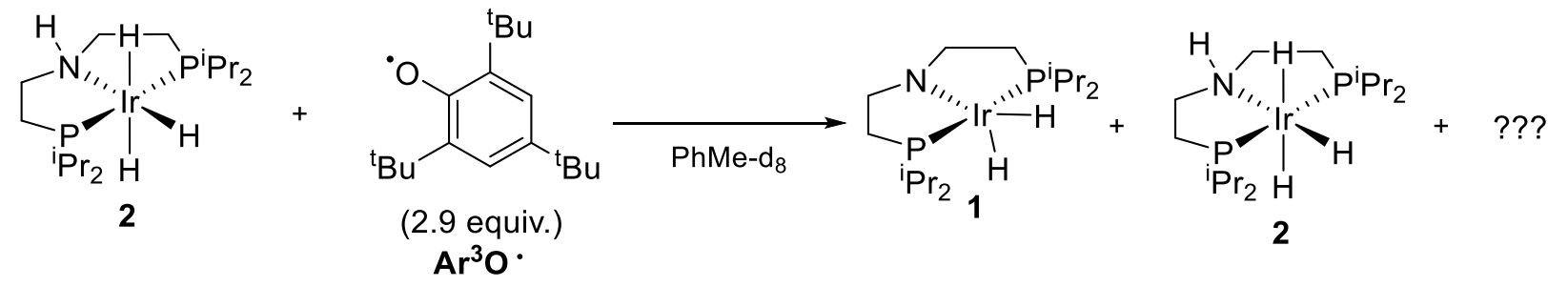

Partial Oxidation of IrH 2 to IrN 1 with stoichiometric $\mathbf{A r}^{3} \mathbf{O} \cdot$. In a nitrogen-filled glovebox, a gas-tight JYoung NMR tube was charged with $\operatorname{IrN} 1(8.1 \mathrm{mg}, 16 \mu \mathrm{mol})$, THF $(0.850 \mathrm{~mL})$, and isopropanol $(75 \mu \mathrm{L}$, $1.0 \mathrm{mmol}$ ). The J-Young NMR tube was connected to a Schlenk manifold, and the solvents were removed under high vacuum to afford a light-orange solid powder. The tube was returned to the glovebox, and the solid was redissolved in toluene- $d_{8}(0.5 \mathrm{~mL}) .{ }^{1} \mathrm{H}$ and ${ }^{31} \mathrm{P}$ NMR spectroscopy confirmed quantitative conversion of IrN 1 to $\operatorname{IrH} 2$. The tube was returned to the glovebox again, and a solution $\mathbf{A} \mathbf{r}^{3} \mathbf{O} \cdot$ in toluene$d_{8}(288 \mathrm{uL}, 0.16 \mathrm{M}, 47 \mu \mathrm{mol})$ was added to the J-Young tube. The deep blue color of the phenoxyl was quenched rapidly upon contact with solution of $\mathrm{IrH} 2$. The tube was inverted several times to ensure complete mixing, and ${ }^{1} \mathrm{H}$ and ${ }^{31} \mathrm{P}$ NMR spectra were recorded about 20 minutes after the addition of $\mathbf{A r} \mathbf{r}^{3} \mathbf{O} \cdot$ In the ${ }^{1} \mathrm{H}$ NMR spectrum, the hydride signals of IrH $2\left({ }^{1} \mathrm{H}\right.$ NMR $\left(400 \mathrm{MHz}\right.$, toluene- $\left.d_{8}\right) \delta-11.65,-12.34$, and -22.18) and IrN $1\left({ }^{1} \mathrm{H}\right.$ NMR (400 MHz, toluene- $\left.d_{8}\right) \delta$-22.34) are both apparent, as are numerous other unidentified metal hydride peaks $\left({ }^{1} \mathrm{H}\right.$ NMR $\left(400 \mathrm{MHz}\right.$, toluene- $\left.d_{8}\right) \delta-14.34,-14.66,-18.43,-18.77,-19.13$, $-20.15,-20.43,-25.00,-28.14,-28.67)$. Similarly, the ${ }^{31} \mathrm{P}$ NMR spectrum contains unknown peaks $\left({ }^{31} \mathrm{P}\right.$ NMR $\left(400 \mathrm{MHz}\right.$, toluene- $\left.\left.d_{8}\right) \delta 56.28,55.48,32.85\right)$ in addition to those corresponding to $\operatorname{IrH} 2\left({ }^{31} \mathrm{P}\right.$ NMR $\left(400 \mathrm{MHz}\right.$, toluene- $\left.\left.d_{8}\right) \delta 62.58\right)$ and IrN $1\left({ }^{31} \mathrm{P}\right.$ NMR $\left(400 \mathrm{MHz}\right.$, toluene- $\left.\left.d_{8}\right) \delta 80.57\right)$.

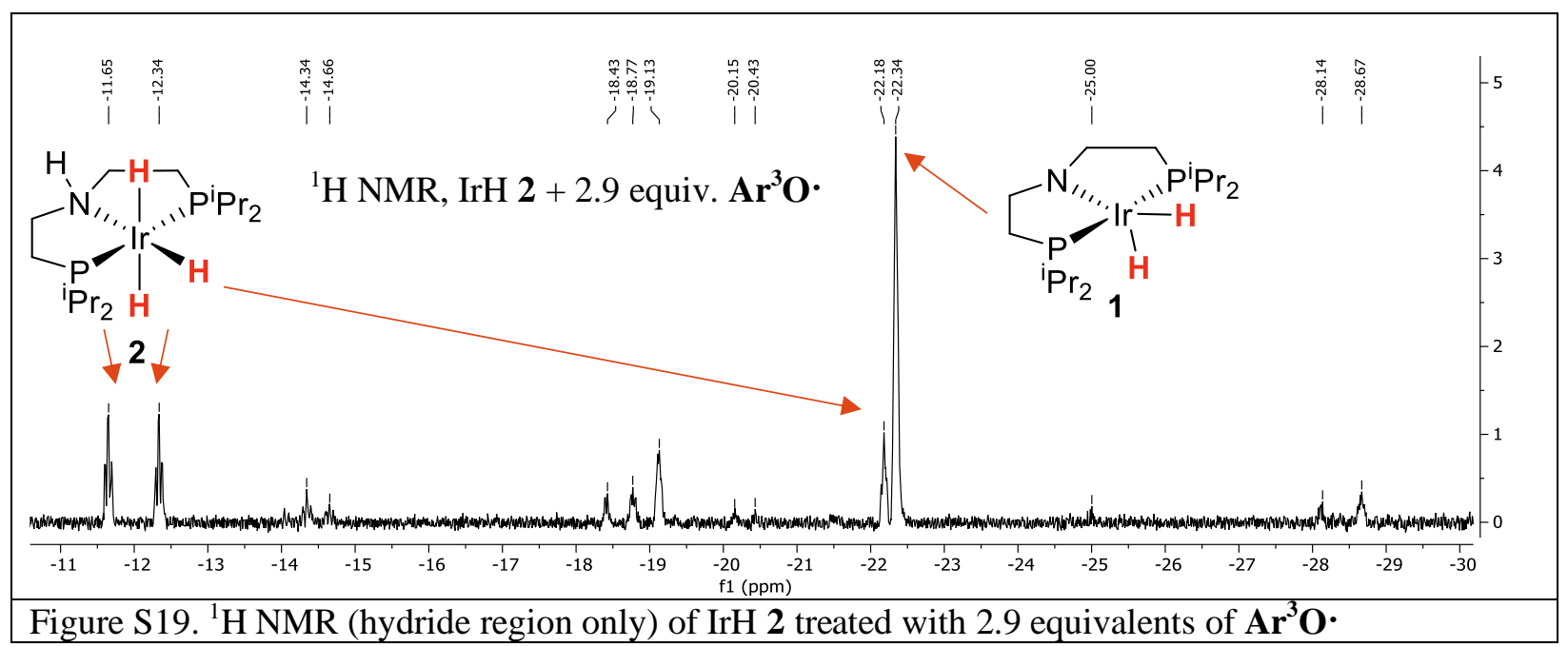




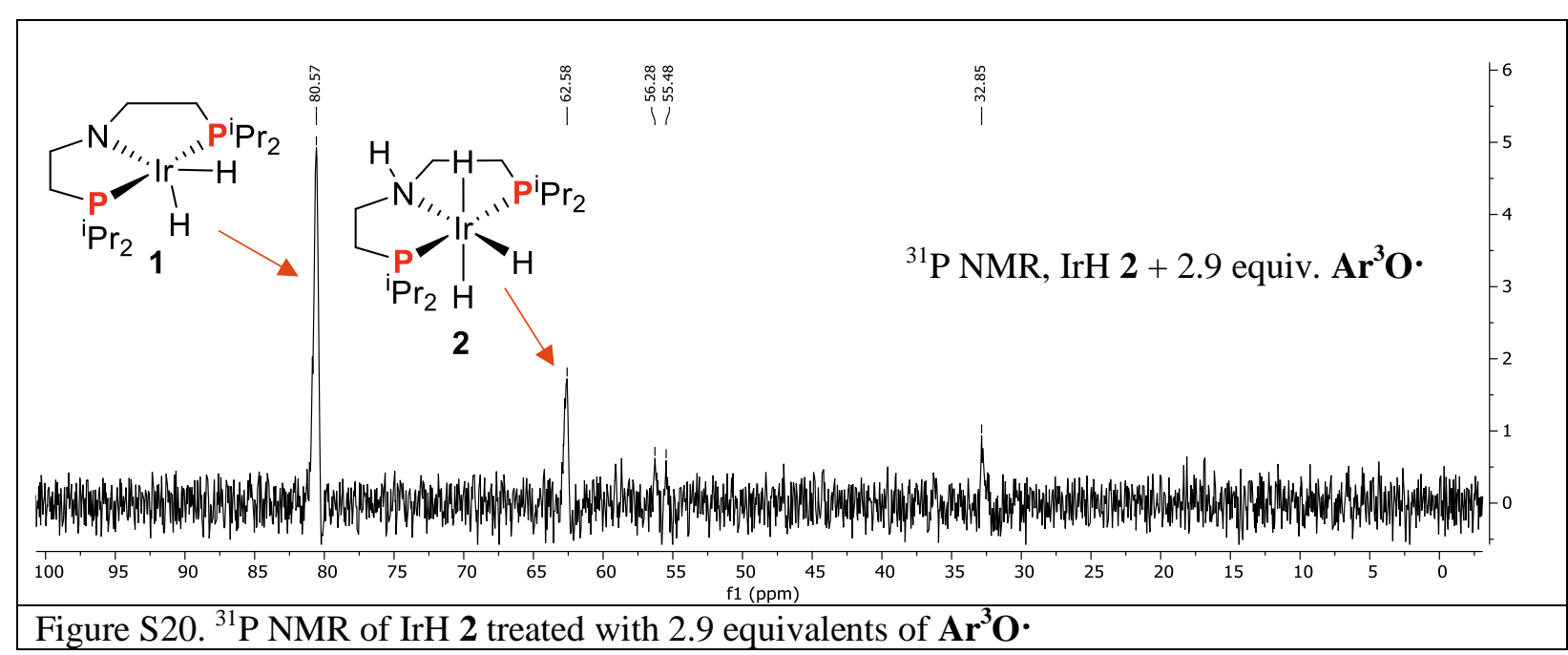




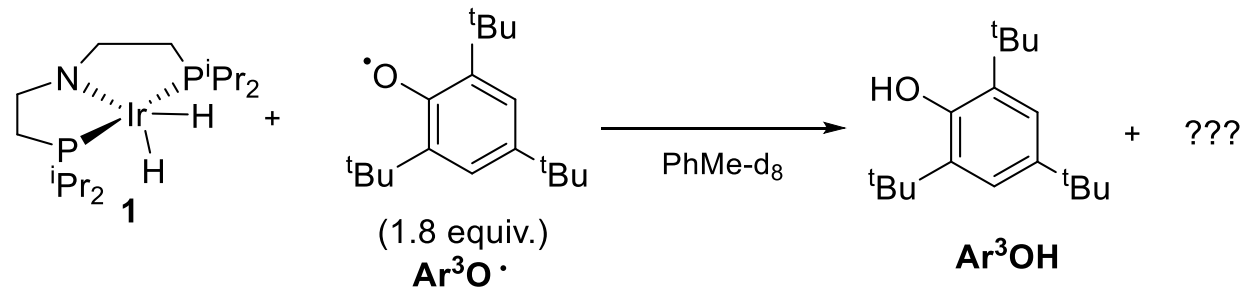

Overoxidation of IrN 1 with stoichiometric $\mathrm{Ar}^{3} \mathrm{O} \cdot$. In a nitrogen-filled glovebox, a gas-tight J-Young NMR tube was charged with $\operatorname{IrN} 1(4.9 \mathrm{mg}, 10 \mu \mathrm{mol})$ and toluene- $d_{8}(0.450 \mathrm{~mL})$. A solution $\mathbf{A r}^{3} \mathbf{O} \cdot$ in toluene- $d_{8}$ (278 uL, $0.063 \mathrm{M}, 18 \mu \mathrm{mol}$ ) was added to the J-Young tube. The deep blue color of the phenoxyl was quenched rapidly upon contact with solution of $\operatorname{IrN} 1$. The tube was inverted several times to ensure complete mixing, and ${ }^{1} \mathrm{H}$ and ${ }^{31} \mathrm{P}$ NMR spectra were recorded about 20 minutes after the addition of $\mathbf{A r} \mathbf{r}^{3} \mathbf{O} \cdot$ Residual hydride $\left({ }^{1} \mathrm{H}\right.$ NMR $\left(400 \mathrm{MHz}\right.$, toluene- $\left.\left.d_{8}\right) \delta-22.34\right)$ and phosphine signals $\left(\left({ }^{31} \mathrm{P}\right.\right.$ NMR $(400 \mathrm{MHz}$, toluene- $\left.d_{8}\right) \delta$ 80.58) IrN 1 are apparent, and the characteristic peaks of $\mathbf{A r}^{3} \mathbf{O H}\left({ }^{1} \mathrm{H}\right.$ NMR (400 MHz, toluene- $\left.\left.d_{8}\right) \delta 1.32(\mathrm{~s}, 9 \mathrm{H}, t \mathrm{Bu}) \delta 1.40(\mathrm{~s}, 18 \mathrm{H}, 2 t \mathrm{Bu}) \delta 4.77(\mathrm{~s}, 1 \mathrm{H}, \mathrm{OH}) \delta 7.32(\mathrm{~s}, 2 \mathrm{H}, \mathrm{ArH})\right)$ are evident as well. Several new and identified signals ( ${ }^{1} \mathrm{H}$ NMR (400 MHz, toluene- $\left.\left.d_{8}\right) \delta-23.59,-24.34,-24.99\right)$ are observed in the hydride region. This suggests that rapid overoxidation of $\operatorname{IrN} \mathbf{1}$ in combination with poor mixing are possible causes of the complex product mixture observed in the treatment of IrH 2 with stoichiometric $\mathbf{A r}^{3} \mathbf{O} \cdot$ in the previous experiment.

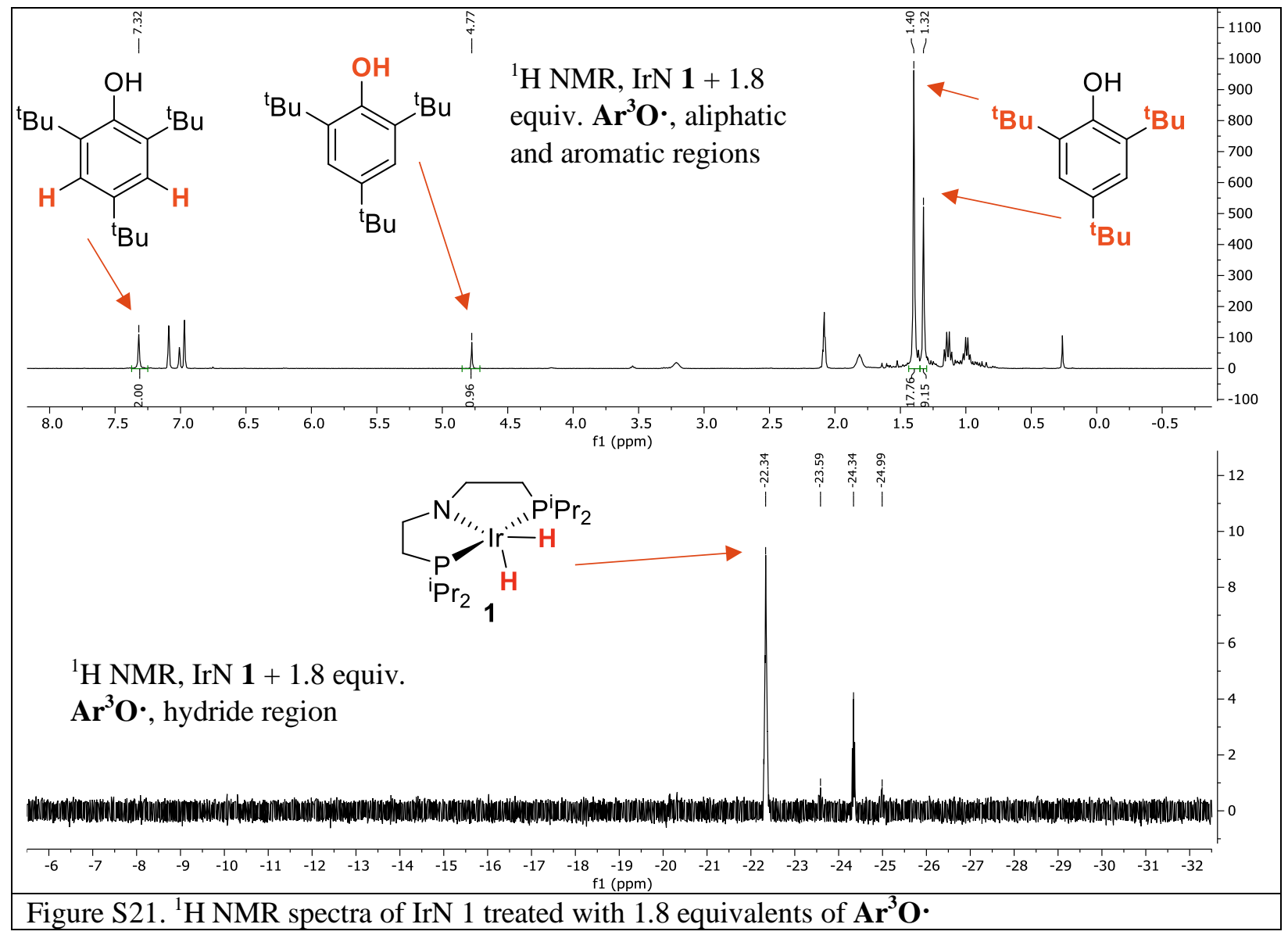




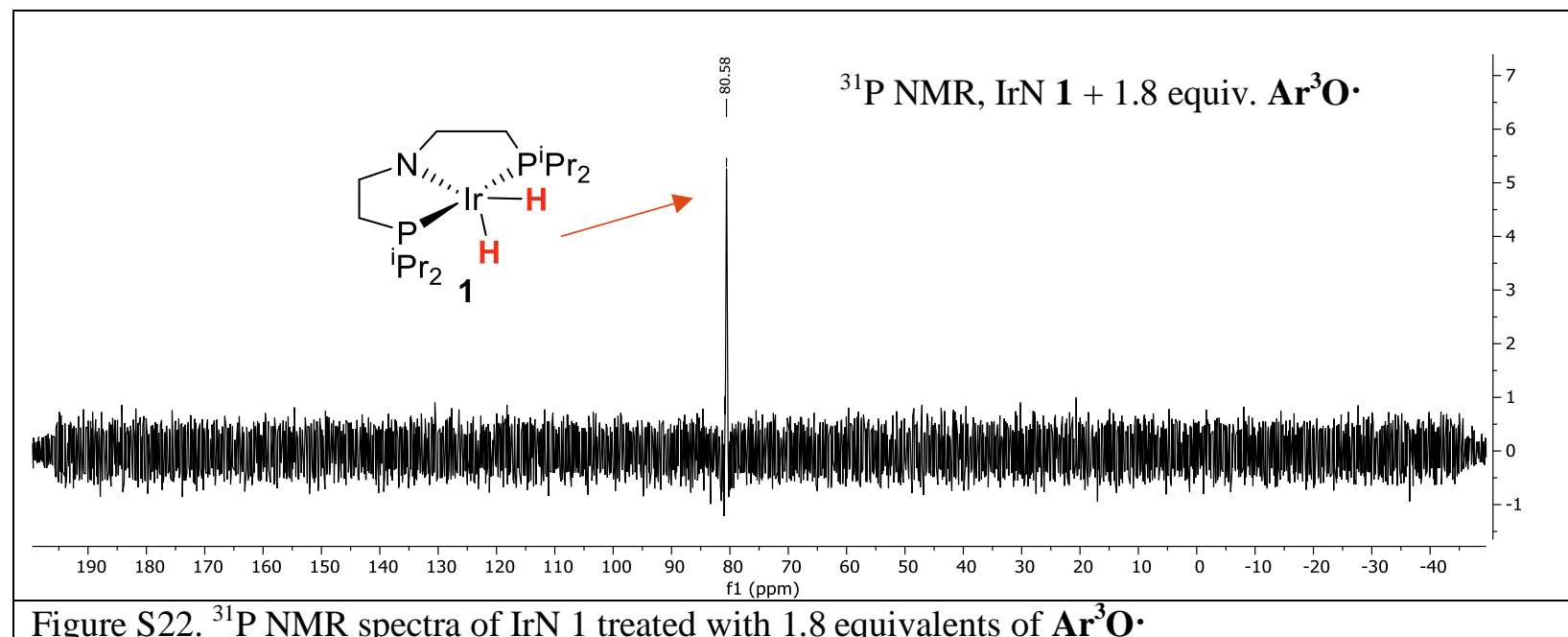




\section{Evaluation of Candidate Phenoxyl Mediators}

Candidate phenoxyls $\mathbf{A r}^{\mathrm{x}} \mathbf{O} \cdot$ were evaluated by cyclic voltammetry. Generally, IrH 2 was titrated into a $\sim 1 \mathrm{mM}$ THF solution of the parent phenol $\mathbf{A r}^{\mathrm{x}} \mathbf{O H}$ in the presence of excess $\mathrm{P}_{2}$-Et, $\sim 400 \mathrm{mM}$ isopropanol, and $\sim 100 \mathrm{mM} \mathrm{NBu}_{4} \mathrm{BF}_{4}$. Changes in the shape and height of the $\mathbf{A r}^{\mathrm{x}} \mathbf{O}-/ \mathbf{A r}^{\mathrm{x}} \mathbf{O} \cdot$ wave were observed.

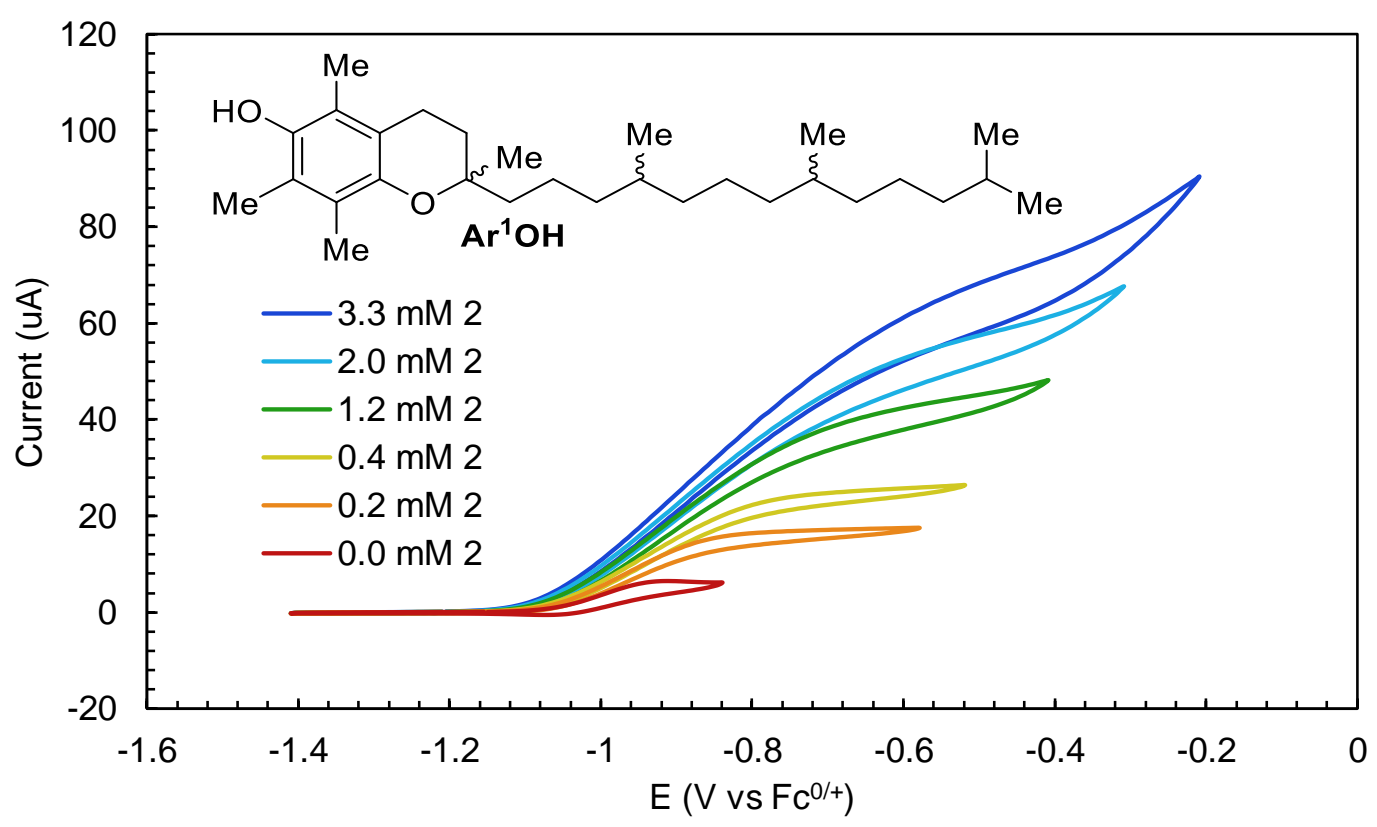

Figure S23. (Reproduction of Figure 10). Titration of $\alpha$-rac-tocopherol $\mathbf{A r}^{1} \mathbf{O H}$ with $\operatorname{IrH} 2(0.75 \mathrm{mM}$ Ar $^{1} \mathbf{O H}, 23 \mathrm{mM} \mathrm{P}$-Et, $400 \mathrm{mM}$ isopropanol, $100 \mathrm{mM} \mathrm{NBu}_{4} \mathrm{BF}_{4}$ in THF, $v=25 \mathrm{mV} / \mathrm{s}$ )

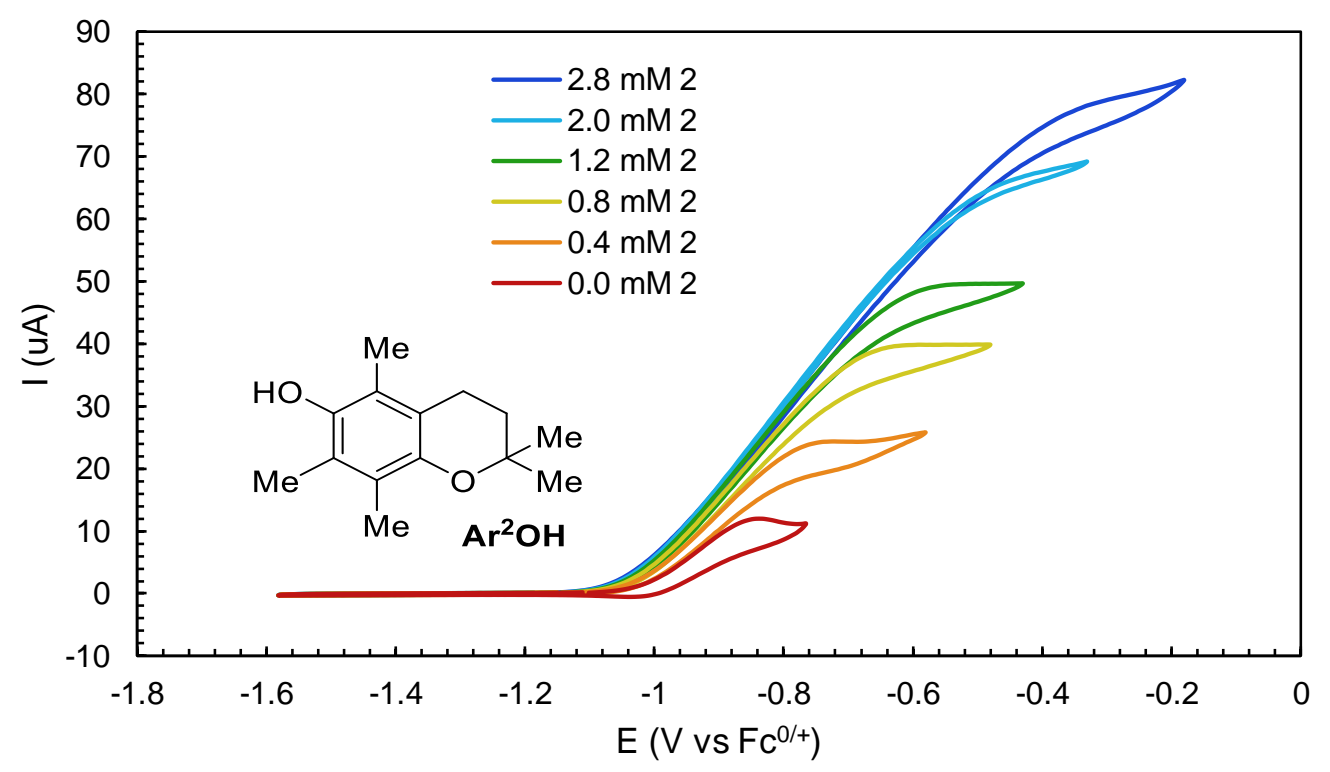

Figure S24. Titration of 2,2,5,7,8-pentamethyl-6-chromanol $\mathbf{A r}^{2} \mathbf{O H}$ with $\mathrm{IrH} 2\left(1.1 \mathrm{mM} \mathbf{A r}^{2} \mathbf{O H}, 67 \mathrm{mM}\right.$ $\mathrm{P}_{2}$-Et, $380 \mathrm{mM}$ isopropanol, $100 \mathrm{mM} \mathrm{NBu}_{4} \mathrm{BF}_{4}$ in THF, $v=25 \mathrm{mV} / \mathrm{s}$ ) 


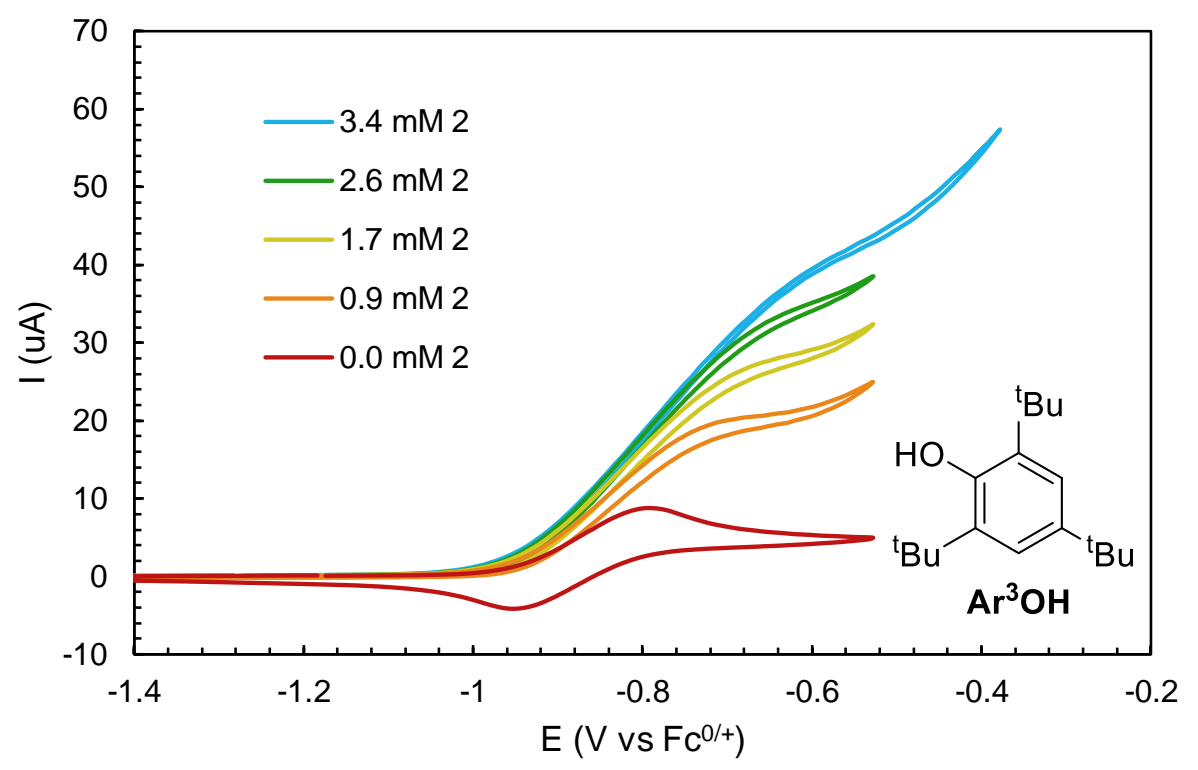

Figure S25. Titration of 2,4,6-tri-tert-butylphenol $\mathbf{A r}^{3} \mathbf{O H}$ with $\operatorname{IrH} 2$ (1.1 mM Ar $\mathbf{~ r ~}^{3} \mathbf{O H}, 78 \mathrm{mM} \mathrm{P}$-Et, 370 $\mathrm{mM}$ isopropanol, $100 \mathrm{mM} \mathrm{NBu} \mathrm{BF}_{4}$ in THF, $v=25 \mathrm{mV} / \mathrm{s}$ )

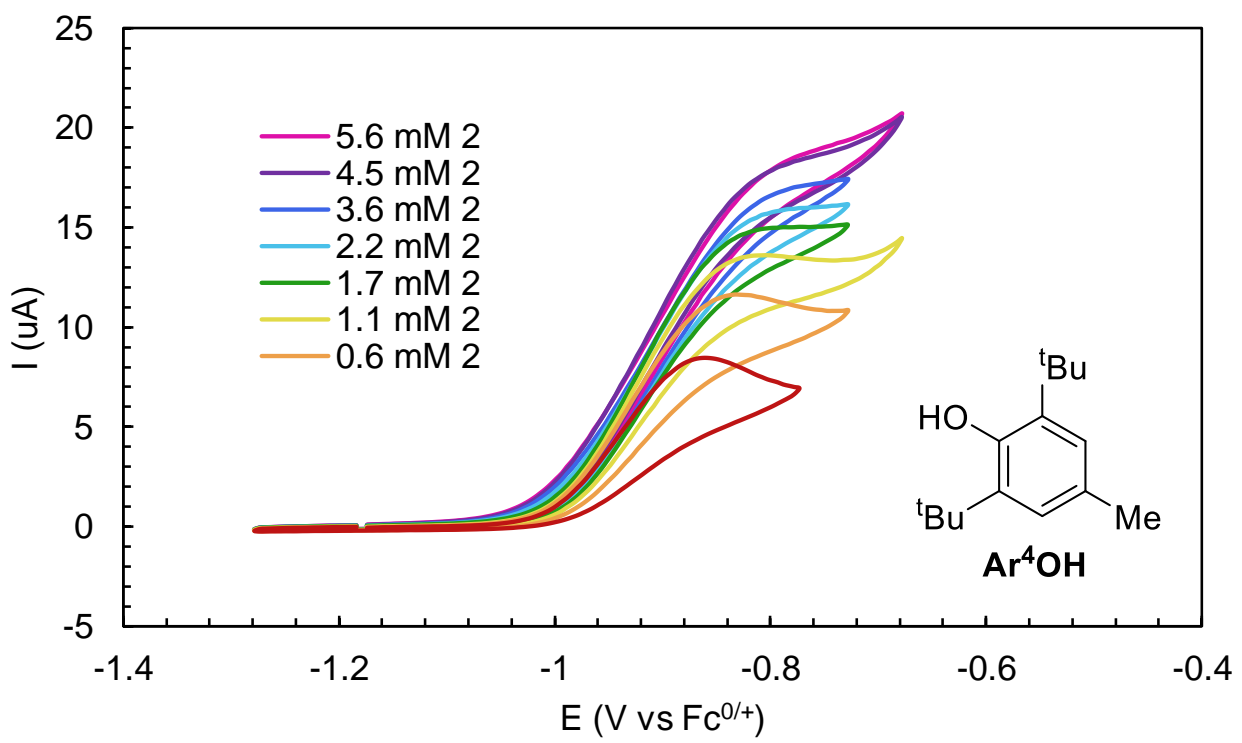

Figure S26. Titration of butylated hydroxytoluene $\mathbf{A r}^{4} \mathbf{O H}$ with IrH 2 (1.1 mM Ar $\mathbf{4}^{4} \mathbf{O H}, 15 \mathrm{mM} \mathrm{P}$-Et, 370 $\mathrm{mM}$ isopropanol, $100 \mathrm{mM} \mathrm{NBu}_{4} \mathrm{BF}_{4}$ in THF, $v=25 \mathrm{mV} / \mathrm{s}$ ) 


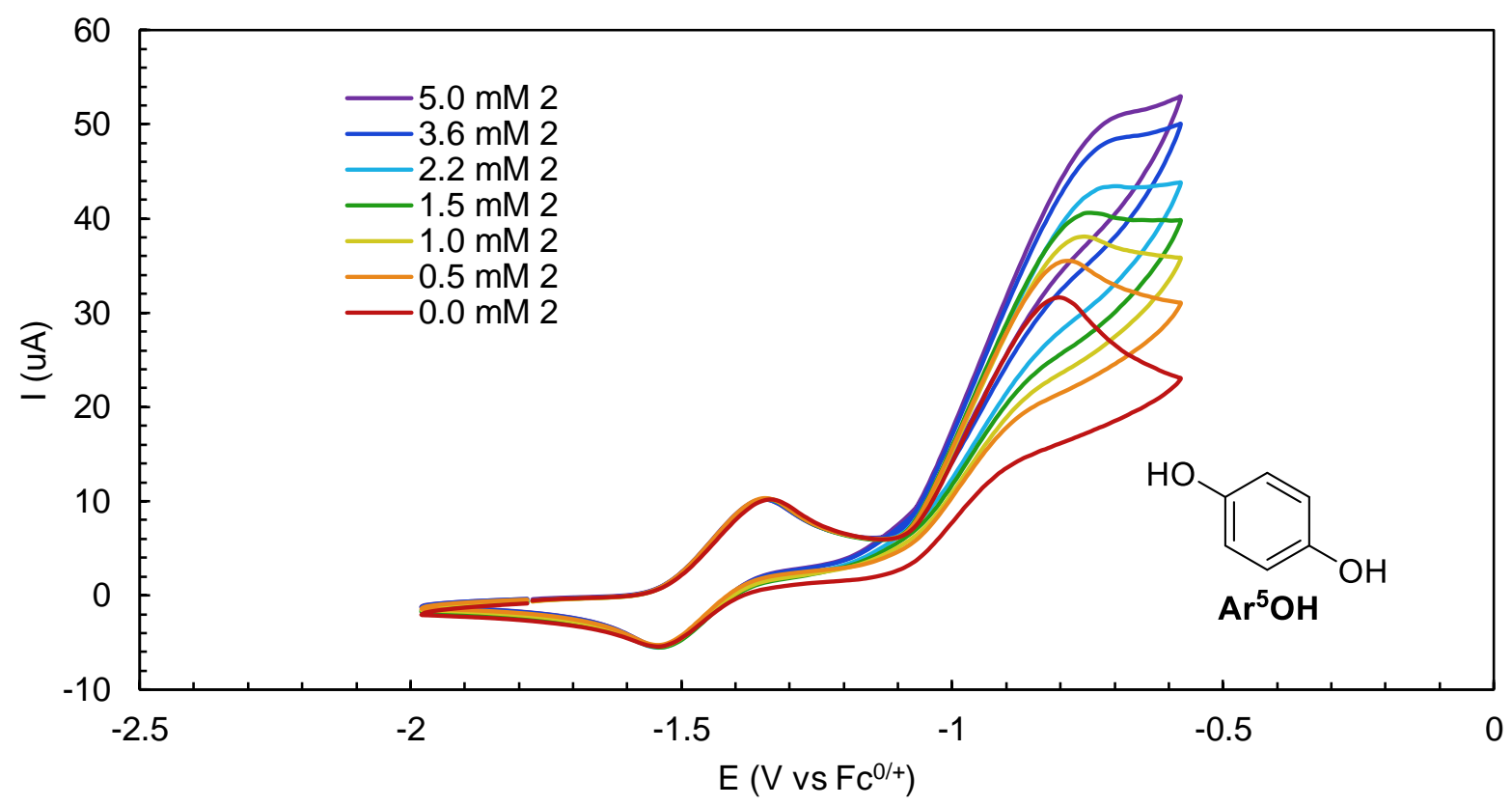

Figure S27. Titration of 1,4-hydroquinone $\mathbf{A r}^{\mathbf{5}} \mathbf{O H}$ with $\operatorname{IrH} 2$ (1.1 mM Ar $\mathbf{r}^{\mathbf{5}} \mathbf{O H}, 78 \mathrm{mM} \mathrm{P}$-Et, $370 \mathrm{mM}$ isopropanol, $100 \mathrm{mM} \mathrm{NBu}_{4} \mathrm{BF}_{4}$ in THF, $v=25 \mathrm{mV} / \mathrm{s}$ )

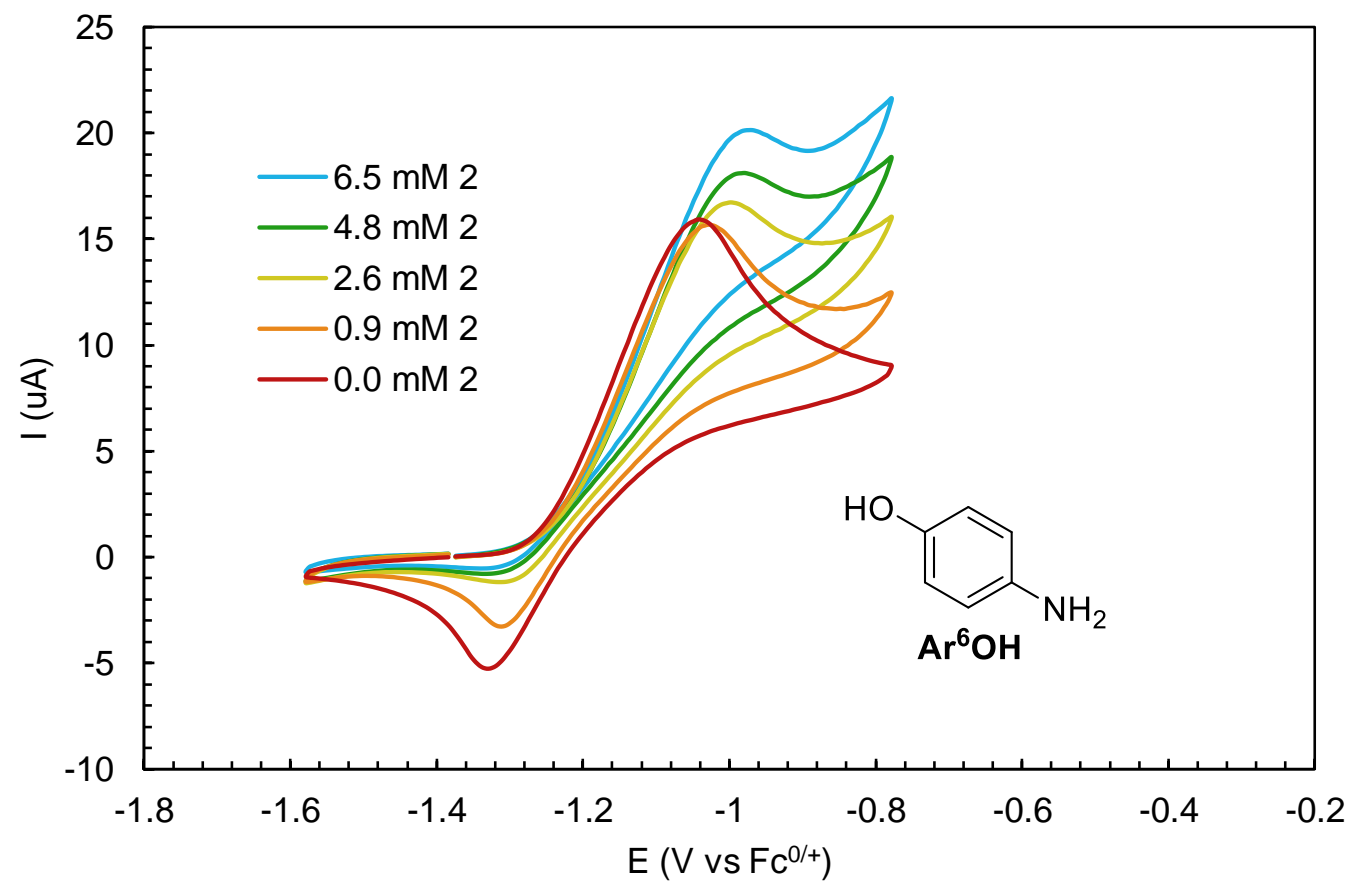

Figure S28. Titration of para-aminophenol $\mathbf{A r}^{6} \mathbf{O H}$ with $\mathrm{IrH} 2\left(1.0 \mathrm{mM}\right.$ Ar $\mathbf{r}^{6} \mathbf{O H}, 37 \mathrm{mM} \mathrm{P}$-Et, $370 \mathrm{mM}$ isopropanol, $100 \mathrm{mM} \mathrm{NBu}_{4} \mathrm{BF}_{4}$ in THF, $v=25 \mathrm{mV} / \mathrm{s}$ ) 


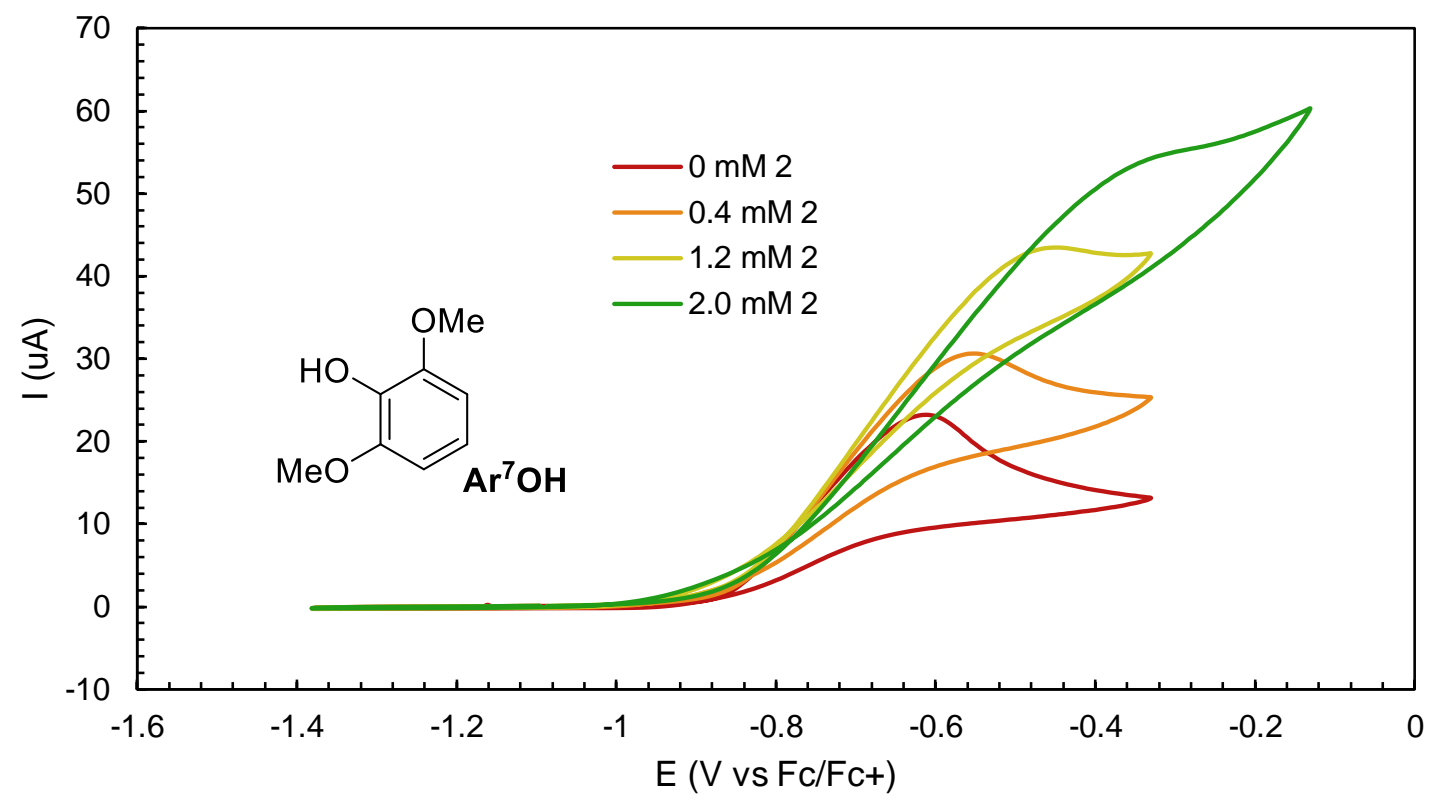

Figure S29. Titration of 2,6-dimethoxyphenol $\mathbf{A r}^{7} \mathbf{O H}$ with $\operatorname{IrH} 2$ (1.5 mM Ar $\mathbf{r}^{7} \mathbf{O H}, 67 \mathrm{mM} \mathrm{P}_{2}$-Et, 370 $\mathrm{mM}$ isopropanol, $100 \mathrm{mM} \mathrm{NBu}_{4} \mathrm{BF}_{4}$ in THF, $v=25 \mathrm{mV} / \mathrm{s}$ ). The peak of the $\mathbf{A r}^{7} \mathbf{O}^{-} / \mathbf{A r}^{7} \mathbf{O}^{\bullet}$ wave overlaps substantially with the onset of direct electrocatalysis with $\operatorname{IrH} 2\left(\mathrm{E}_{\mathrm{onset}}=-0.65 \mathrm{~V} \mathrm{vs} \mathrm{Fc}^{0 /+}\right)$.

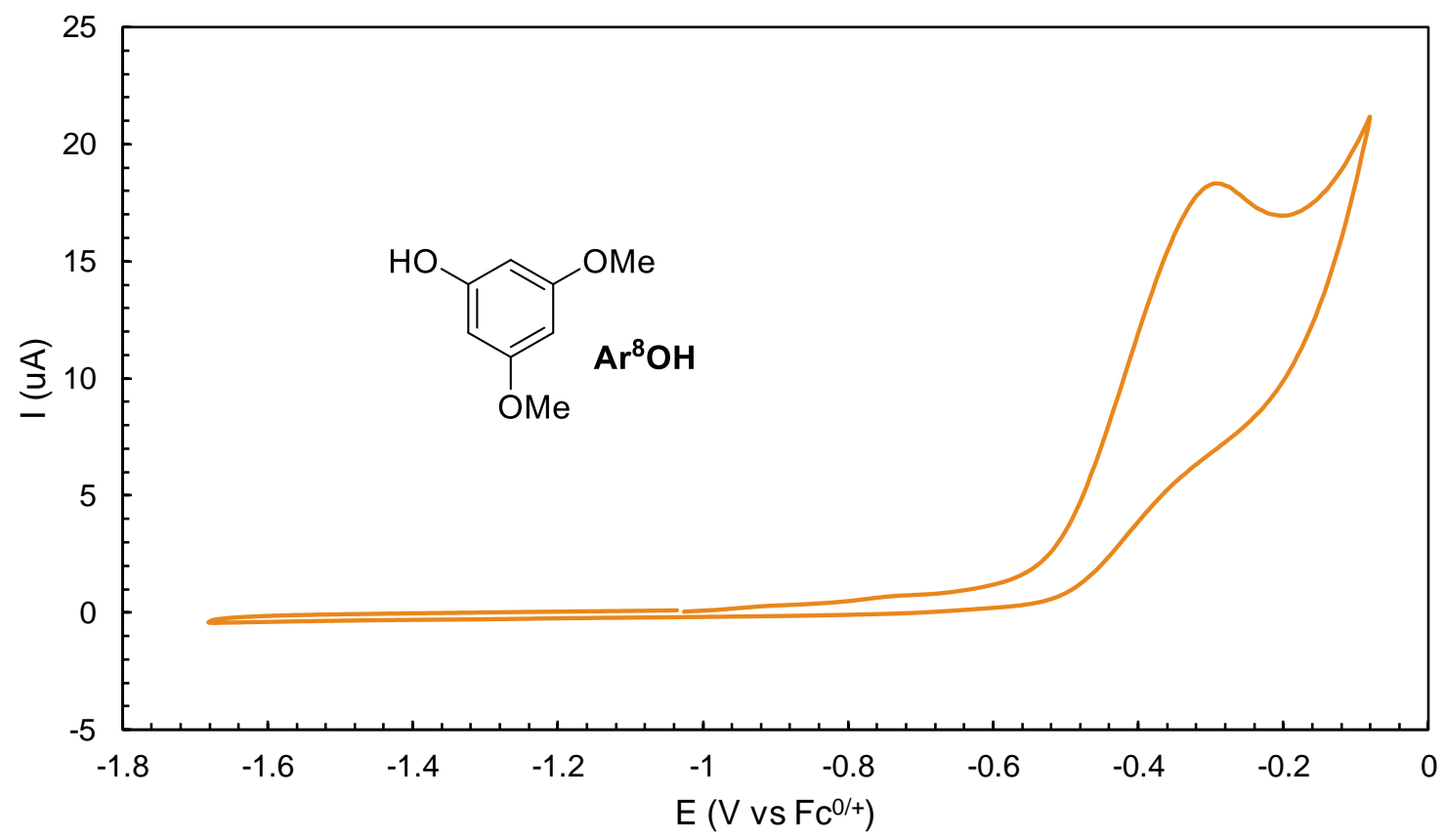

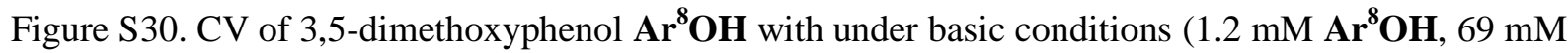
$\mathrm{P}_{2}$-Et, $370 \mathrm{mM}$ isopropanol, $100 \mathrm{mM} \mathrm{NBu}_{4} \mathrm{BF}_{4}$ in THF, $\left.v=25 \mathrm{mV} / \mathrm{s}\right)$. The onset of the $\mathbf{A r}^{8} \mathbf{O}^{-} / \mathbf{A r}^{8} \mathbf{O}^{\cdot}$ wave is too anodic relative to the onset potential of unmediated electrocatalysis with $\operatorname{IrH} 2\left(\mathrm{E}_{\text {onset }}=-0.65\right.$ $\mathrm{V}$ vs $\left.\mathrm{Fc}^{0 /+}\right)$. 


\section{Calculation of $\mathrm{k}_{\mathrm{obs}}$ and $\mathrm{k}_{1}$ for ECHAT with $\mathrm{Ar}^{2} \mathrm{OH}, \mathrm{Ar}^{3} \mathrm{OH}$, and $\mathrm{Ar}^{4} \mathrm{OH}$}
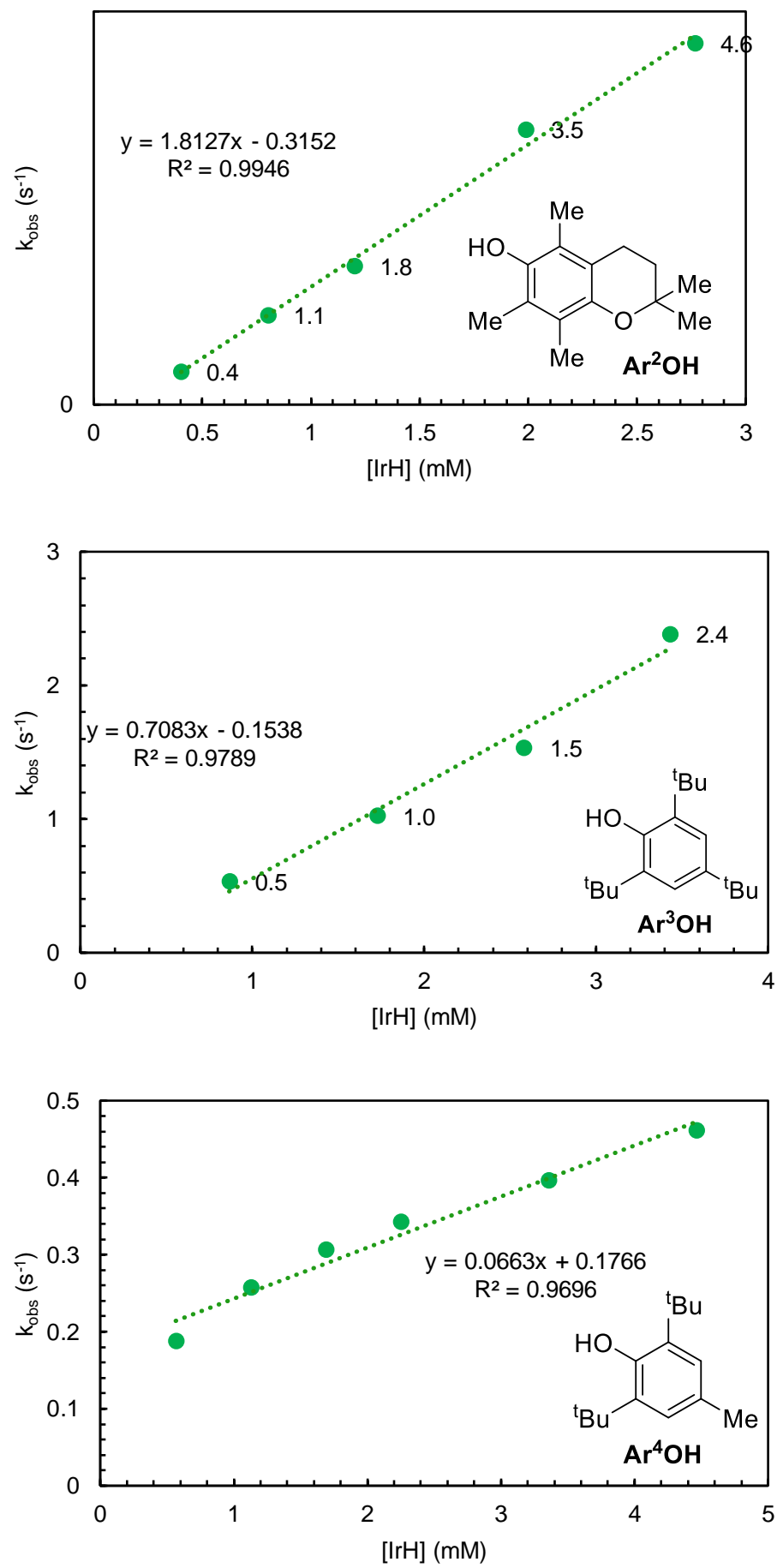

Figure S31. $\mathrm{k}_{\mathrm{obs}}$ vs [IrH] for ECHAT with $\mathbf{A r}^{2} \mathbf{O H}$. This data reflects the voltammograms in Figure S24. As described in the text, the slope of this graph corresponds to the rate constant of the rate-defining HAT event between $\mathrm{IrH} \mathbf{2}$ and $\mathbf{A r}^{2} \mathbf{O} \cdot$, so $\mathrm{k}_{1}=$ $1810 \mathrm{M}^{-1} \mathrm{~s}^{-1}$.

Figure S32. $\mathrm{k}_{\mathrm{obs}} \mathrm{vs}$ [IrH] for ECHAT with $\mathbf{A r}^{3} \mathbf{O H}$. This data reflects the voltammograms in Figure S25. As described in the text, the slope of this graph corresponds to the rate constant of the rate-defining HAT event between $\operatorname{IrH} \mathbf{2}$ and $\mathbf{A r}^{3} \mathbf{O} \cdot$, so $\mathrm{k}_{1}=710$ $\mathrm{M}^{-1} \mathrm{~s}^{-1}$.

Figure S33. $\mathrm{k}_{\mathrm{obs}} \mathrm{vs}$ [IrH] for ECHAT with $\mathbf{A r}^{4} \mathbf{O H}$. This data reflects the voltammograms in Figure S26. As described in the text, the slope of this graph corresponds to the rate constant of the rate-defining HAT event between $\mathrm{IrH} \mathbf{2}$ and $\mathbf{A \mathbf { r } ^ { 4 }} \mathbf{O}^{\cdot}$, so $\mathrm{k}_{1}=70$ $\mathrm{M}^{-1} \mathrm{~s}^{-1}$. However, the non-zero intercept of this plot suggests that decomposition of $\mathbf{A r}^{\mathbf{4}} \mathbf{O} \cdot$ may be competitive with $\mathrm{H}$-atom abstraction from IrH 2. 


\section{Scan rate study for $\mathrm{Ar}^{1} \mathrm{OH}-$ mediated electrocatalysis}

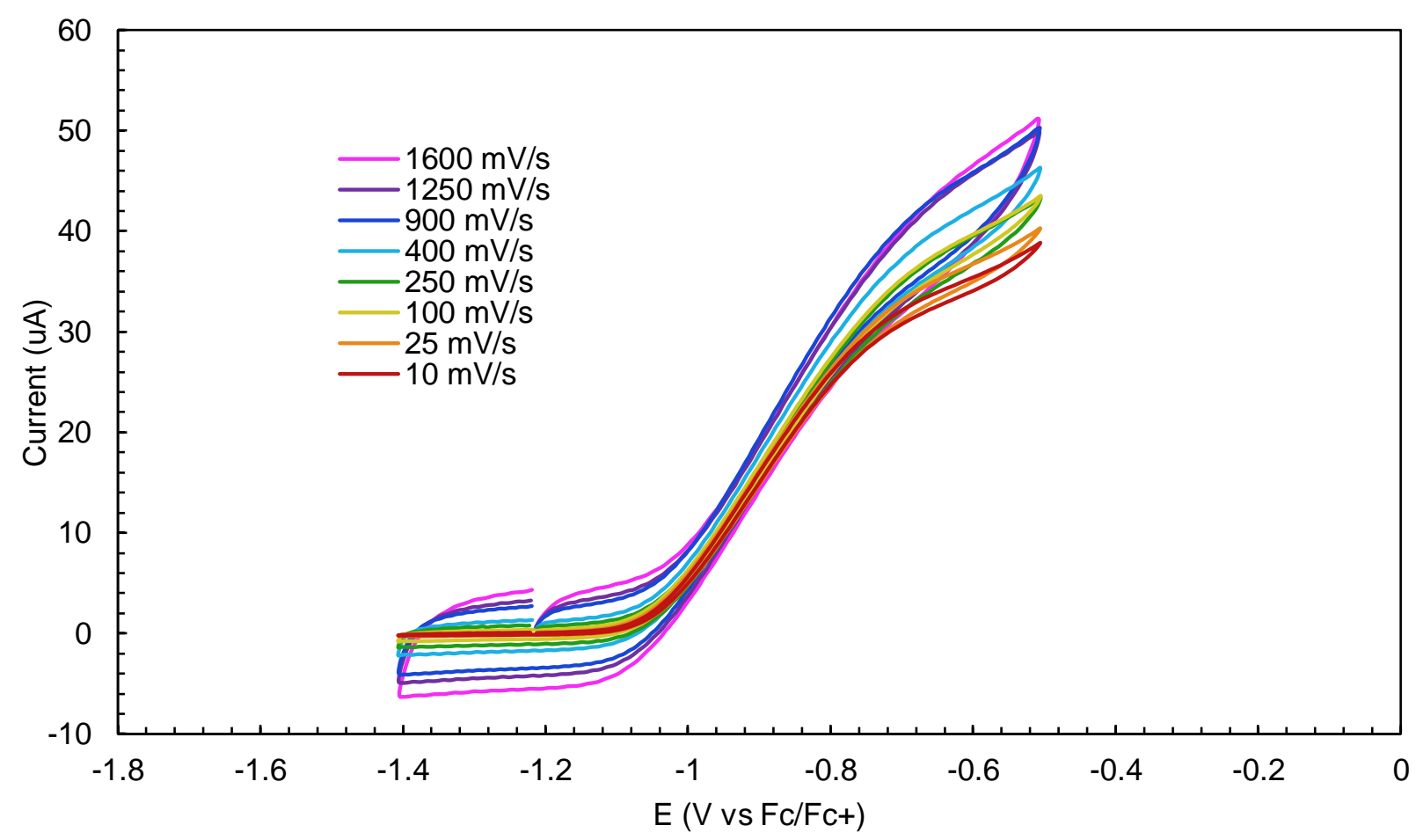

Figure S34. The plateau current of ECHAT is independent of scan rate $\left(0.75 \mathrm{mM} \mathrm{Ar}^{1} \mathbf{O H}, 1.4\right.$ $\mathrm{mM} \mathrm{2,} 23 \mathrm{mM} \mathrm{P}_{2}$-Et, $460 \mathrm{mM}$ isopropanol, $100 \mathrm{mM} \mathrm{NBu}_{4} \mathrm{BF}_{4}$ in THF)

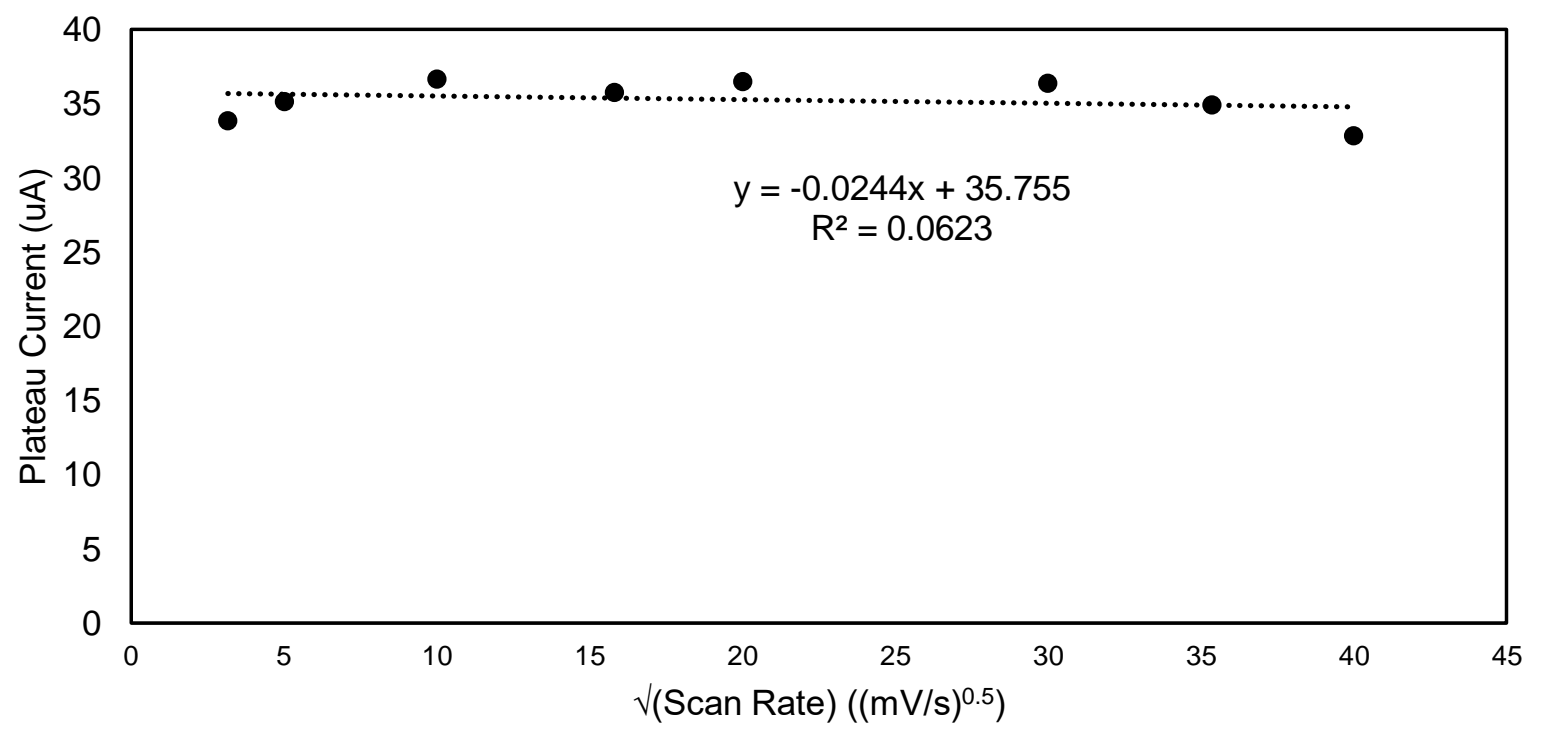

Figure S35. Plateau current of ECHAT vs. (scan rate $)^{1 / 2}$. Data are representative of the voltammograms in Figure S34 (0.75 mM Ar1 OH, 1.4 mM 2, 23 mM P P $_{2}$ Et, $460 \mathrm{mM}$ isopropanol, $100 \mathrm{mM} \mathrm{NBu}_{4} \mathrm{BF}_{4}$ in THF) 


\section{Derivation of the TOF and Plateau Current Formulas for Phenoxyl-Mediated Electrocatalysis}

This derivation of equations (1) and (3) follows the methods developed by Saveant ${ }^{3}$ and applied in the context of mediated catalysis by Stahl. ${ }^{4}$

Iridium/tocopherol ECHAT proceeds via the elementary steps in Figure S36, which are reproduced from Figure 14:

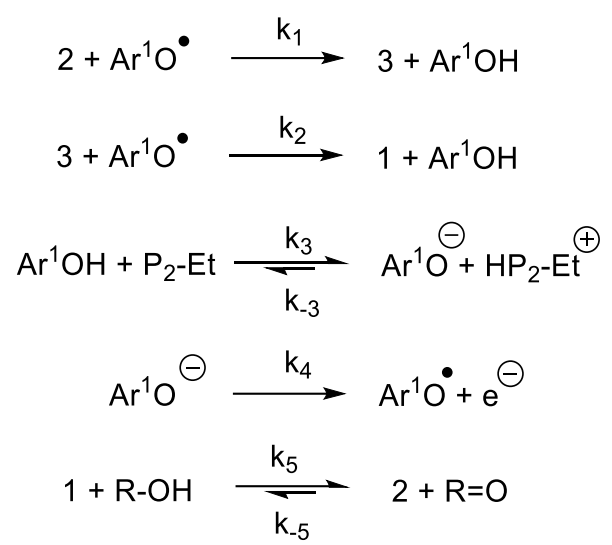

Figure S36. Elementary Steps of ECHAT

Where $\mathrm{IrN}$ is the iridium amido complex $\mathbf{1}, \mathrm{IrH}$ is the iridium amino trihydride $\mathbf{2}$, and $\mathrm{Ir} \cdot$ is an iridium radical intermediate 3 .

Per definitions described by Dempsey ${ }^{5-6}$ the fact that there is only one type of heterogeneous electron transfer means that this is necessarily an EC mechanism. However, we can derive this fact explicitly and show that the formula for plateau current for this ECHAT system is indeed the formula for plateau current for an EC mechanism with an extra coefficient accounting for the fact that two equivalents of phenol must turn over per equivalent of substrate.

First, the elementary chemical steps are simplified according to the method used by Stahl. ${ }^{2}$ In Stahl's Cu/TEMPO system, the experimental plateau current depends on [Cu], [TEMPO], and [ROH] but not [Base]. Ergo, the mechanism is simplified to exclude base and the conjugate acid under the assumption that steps involving those species are extremely fast. We apply the same logic here to the phenoxyl-mediated iridium catalysis. Experimental plateau currents for this system depend only on [IrH] and $\left[\mathrm{Ar}^{1} \mathrm{OH}\right]$, not on $[\mathrm{ROH}]$ nor $\left[\mathrm{P}_{2}-\mathrm{Et}\right]$. Therefore, we assume that steps 3 and 5 are fast compared to the other two homogeneous chemical steps. Since $\mathrm{P}_{2}$-Et is a stronger base than $\mathrm{Ar}^{1} \mathrm{O}^{-}$, and $\mathrm{IrH}$ is the sole iridium species observed in the presence of excess isopropanol, we ignore the reverse reactions of steps 3 and 5. This means that any $\operatorname{IrN} 1$ that is produced is immediately hydrogenated to $\operatorname{IrH} 2$. Any $\operatorname{Ar}^{1} \mathrm{OH}$ that is produced is immediately deprotonated to $\mathrm{Ar}^{1} \mathrm{O}$-. We therefore assume steady-state for $\operatorname{IrN}$ and $\operatorname{Ar}^{1} \mathrm{OH}$ :

$$
\begin{gathered}
d\left[\mathrm{Ar}^{1} \mathrm{OH}\right] / d t=0 \\
d[\operatorname{IrN}] / d t=0
\end{gathered}
$$

From these steady-state assumptions, it follows that:

$$
\begin{gathered}
k_{3}\left[A r^{1} O H\right]\left[P_{2}-E t\right]=k_{1}\left[A r^{1} O^{\cdot}\right][I r H]+k_{2}\left[A r^{1} O^{\cdot}\right]\left[I r^{\cdot}\right] \\
k_{5}[I r N][R-O H]=k_{2}\left[A r^{1} O^{\cdot}\right]\left[I r^{\cdot}\right]
\end{gathered}
$$


Now, rates for all four homogeneous chemical steps can be written exclusively in terms of $\mathrm{k}_{1}, \mathrm{k}_{2},\left[\mathrm{Ar}^{1} \mathrm{O}^{\cdot}\right]$, [Ar $\left.{ }^{1} \mathrm{O}-\right],[\mathrm{IrH}]$, and [ $\left.\mathrm{Ir}^{*}\right]$ :

$$
\begin{gathered}
\text { rate }_{1}=k_{1}\left[\mathrm{Ar}^{1} O^{\circ}\right][\mathrm{IrH}] \\
\text { rate }_{2}=k_{2}\left[\mathrm{Ar}^{1} O^{\cdot}\right]\left[\mathrm{Ir}^{\cdot}\right] \\
\text { rate }_{3}=k_{1}\left[\mathrm{Ar}^{1} O^{\cdot}\right][\operatorname{IrH}]+k_{2}\left[\mathrm{Ar}^{1} O^{\cdot}\right]\left[\mathrm{Ir}^{\cdot}\right] \\
\text { rate }_{3}=k_{2}\left[\mathrm{Ar}^{1} O^{\cdot}\right]\left[\mathrm{Ir}^{\cdot}\right]
\end{gathered}
$$

Per Saveant, the following are therefore the governing equations for this system:

$$
\begin{aligned}
& \partial\left[\operatorname{Ar}^{1} O^{\cdot}\right] / \partial t=D_{A r^{1} O} \partial^{2}\left[A r^{1} O^{\cdot}\right] / \partial x^{2}-k_{1}\left[A r^{1} O^{\cdot}\right][\operatorname{IrH}]-k_{2}\left[A r^{1} O^{\cdot}\right]\left[\operatorname{Ir}^{\cdot}\right] \\
& \partial\left[\operatorname{Ar}^{1} O_{-}\right] / \partial t=D_{A r^{1} O} \partial^{2}\left[A r^{1} O_{-}\right] / \partial x^{2}+k_{1}\left[A r^{1} O^{\cdot}\right][\operatorname{IrH}]+k_{2}\left[A r^{1} O^{\cdot}\right]\left[\operatorname{Ir}^{\cdot}\right] \\
& \partial[\operatorname{IrH}] / \partial t=D_{I r} \partial^{2}[\operatorname{IrH}] / \partial x^{2}-k_{1}\left[A r^{1} O^{\cdot}\right][\operatorname{IrH}]+k_{2}\left[A r^{1} O^{\cdot}\right]\left[\operatorname{Ir}^{\cdot}\right] \\
& \partial\left[\operatorname{Ir}^{\cdot}\right] / \partial t=D_{I r} \partial^{2}\left[\operatorname{Ir}^{\cdot}\right] / \partial x^{2}+k_{1}\left[A r^{1} O^{\cdot}\right][\operatorname{IrH}]-k_{2}\left[A r^{1} O^{\cdot}\right]\left[I r^{\cdot}\right]
\end{aligned}
$$

$\mathrm{D}$ is a diffusion coefficient that is assumed to be constant for all iridium species and the same for all phenol species. It is possible to derive formulas for current at any potential, but only the formula for plateau current is necessary for determining turnover frequency. Plateau current conditions mean that the concentration of substrate is the same at the anode as it is in the bulk. In the context of phenoxyl-mediated catalysis, IrH 2 is the "substrate." Thus:

$$
\partial[\operatorname{IrH}] / \partial t=D_{I r} \partial^{2}[\operatorname{IrH}] / \partial x^{2}=0
$$

Which in turn means:

$$
k_{1}\left[A r^{1} O^{\cdot}\right][\operatorname{IrH}]=k_{2}\left[A r^{1} O^{\cdot}\right]\left[\operatorname{Ir}^{\cdot}\right]
$$

The governing equations can then be simplified to:

$$
\begin{gathered}
\partial\left[\operatorname{Ar}^{1} O^{\cdot}\right] / \partial t=D_{A r^{1} O} \partial^{2}\left[A r^{1} O^{\cdot}\right] / \partial x^{2}-2 k_{1}\left[A r^{1} O^{\cdot}\right][\operatorname{IrH}] \\
\partial\left[A r^{1} O_{-}\right] / \partial t=D_{A r^{1} O} \partial^{2}\left[A r^{1} O^{-}\right] / \partial x^{2}+2 k_{1}\left[A r^{1} O^{\cdot}\right][\operatorname{IrH}] \\
\partial\left[\operatorname{Ir}^{\cdot}\right] / \partial t=D_{I r} \partial^{2}\left[\operatorname{Ir}^{\cdot}\right] / \partial x^{2}
\end{gathered}
$$

The definition of the observed current with respect to the concentration of the electroactive species is: 


$$
\left[\partial\left[A r^{1} O-\right] / \partial x\right]_{0}=-\left[\partial\left[A r^{1} O^{\cdot}\right] / \partial x\right]_{0}=-\frac{i_{\text {plateau }}}{F A D_{A r^{1} O}}
$$

Under plateau current conditions, the current is constant irrespective of voltage and time. Therefore, the relevant boundary condition is:

$$
\partial\left[A r^{1} O-\right] / \partial t=\partial\left[A r^{1} O^{\cdot}\right] / \partial t=0
$$

We can use this boundary condition to simplify the first governing equation to:

$$
D_{A r^{1} O} \partial^{2}\left[A r^{1} O^{\cdot}\right] / \partial x^{2}=2 k_{1}\left[A r^{1} O^{\cdot}\right][\operatorname{IrH}]
$$

We rearrange and make the substitutions that

$$
\begin{gathered}
\frac{2 k_{1}[\operatorname{IrH}]}{D_{A r^{1} O}}=C \\
{\left[A r^{1} O^{\cdot}\right]=y}
\end{gathered}
$$

To obtain the second order differential equation

$$
\partial^{2} y / \partial x^{2}-C y=0
$$

Here, $\mathrm{y}$ is necessarily of the form $\mathrm{e}^{\mathrm{kx}}$ where $\mathrm{k}$ is a constant. Therefore, we know the following:

$$
\begin{gathered}
\partial^{2} y / \partial x^{2}=k^{2} e^{k x} \\
\partial y / \partial x=k e^{k x} \\
y=e^{k x}
\end{gathered}
$$

And the differential equation becomes

$$
\begin{gathered}
k^{2} e^{k x}-C e^{k x}=0 \\
e^{k x}\left(k^{2}-C\right)=0
\end{gathered}
$$

$\mathrm{e}^{\mathrm{kx}}$ cannot be 0 , so the only solutions to this occur when $\mathrm{k}^{2}=\mathrm{C}$. Because all of the values in $\mathrm{C}$ are necessarily positive, the only physically meaningful solution is

$$
k=+\sqrt{C}
$$

Now: 


$$
\begin{gathered}
\frac{i_{\text {plateau }}}{F A D_{A r^{1} O}}=\left[\partial\left[A r^{1} O^{\cdot}\right] / \partial x\right]_{0}=[\partial y / \partial x]_{0}=k e^{k x} \\
\frac{i_{\text {plateau }}}{F A D_{A r^{1} O}}=k e^{k x}=k y_{0}
\end{gathered}
$$

Substituting back in for $\mathrm{C}$ and $\mathrm{y}$ gives us:

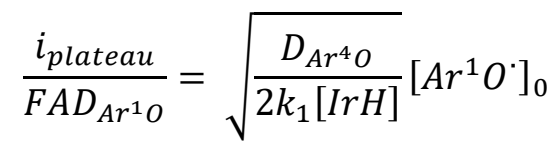

Which can be rearranged to:

$$
i_{\text {plateau }}=F A\left[A r^{1} O^{\cdot}\right]_{0} \sqrt{2 k_{1}[\operatorname{IrH}] D_{A r^{1} O}}
$$

The fact that $[\mathrm{IrH}]$ at the anode is the same as that in the bulk tells us that essentially all of the iridium at the anode is IrH $\mathbf{2}$ is the bulk resting state of the catalyst. Therefore:

$$
[\operatorname{IrH}]_{0}=[\operatorname{IrH}]_{\text {total }}
$$

The fact that the CVs are plateau shaped means that the rate of heterogeneous electron transfer is fast relative to that of the chemical steps. This means the rate at which $\operatorname{Ar}^{1} \mathrm{O}$ - is consumed heterogeneously is fast compared to the rate at which $\mathrm{Ar}^{1} \mathrm{O}^{\cdot}$ is consumed chemically. Therefore, we make the approximation that the concentration of $\mathrm{Ar}^{1} \mathrm{O}^{\cdot}$ at the anode is equal to the total phenolic species concentration.

Explicitly, this means that

$$
\left[A r^{1} O^{\cdot}\right]_{0}=\left[A r^{1} O H\right]_{\text {total }}
$$

And that the rate of catalysis is equation (6):

$$
d[\text { acetone }] /_{d t}=k_{o b s}\left[A r^{1} O^{\cdot}\right]_{0}=k_{o b s}\left[A r^{1} O H\right]_{\text {total }}
$$

The plateau current law can then be rewritten in terms of the known total concentrations of iridium and phenol to give equation (1):

$$
i_{\text {plateau }}=F A\left[A r^{1} O H\right]_{\text {total }} \sqrt{2 k_{1}[\operatorname{IrH}]_{\text {total }} D_{A r^{1} O}}
$$

where $\mathrm{k}_{\mathrm{obs}}$ with respect to isopropanol is equation (8):

$$
k_{\text {obs }(\mathrm{ROH})}=k_{1}[\operatorname{IrH}]_{\text {total }}
$$

Therefore, the rate law for catalysis at the anode is: 


$$
d[\text { acetone }] / d t=k_{o b s}\left[A r^{1} O H\right]_{\text {total }}=k_{1}[\operatorname{IrH}]_{\text {total }}\left[A r^{1} O H\right]_{\text {total }}
$$

The equations show that the rate constant for limiting hydrogen atom transfer $\mathrm{k}_{1}$ can be extracted from the slope of the plot of TOF vs $[\mathrm{IrH}]_{\text {total }}$. The surface area and diffusion constant can be removed from the plateau current formula by dividing by the Randles-Sevcik equation (equation (2)), which governs the peak current for the $\mathrm{Ar}^{4} \mathrm{O}-/ \mathrm{Ar}^{4} \mathrm{O}$ wave under noncatalytic conditions (i.e., in the presence of base and isopropanol but in the absence of iridium):

$$
i_{\text {peak }}=0.4463 F A\left[A r^{1} O H\right]_{\text {total }} \sqrt{\frac{F v D}{R T}}
$$

Where $v$ is the scan rate to give:

$$
\frac{i_{\text {plateau }}}{i_{\text {peak }}}=\frac{1}{0.4463} \sqrt{\frac{2 k_{1}[\operatorname{IrH}]_{\text {total }} R T}{F v}}
$$

Rearrangement enables the direct calculation of $\mathrm{k}_{\mathrm{obs}}$ with respect to isopropanol (eq. 3 ) and the rate constant of the limiting hydrogen atom transfer from experimentally determined plateau and peak currents:

$$
\begin{gathered}
k_{\text {obs }}=k_{1}[I r H]_{\text {total }}=\frac{F v}{2 R T}\left(0.4463 \frac{i_{\text {plateau }}}{i_{\text {peak }}}\right)^{2} \\
k_{1}=\frac{F v}{2 R T[I r H]_{\text {total }}}\left(0.4463 \frac{i_{\text {plateau }}}{i_{\text {peak }}}\right)^{2}
\end{gathered}
$$




\section{Kinetic Isotope Effect of $\mathrm{Ar}^{1} \mathrm{OH}-$ mediated Electrocatalysis}

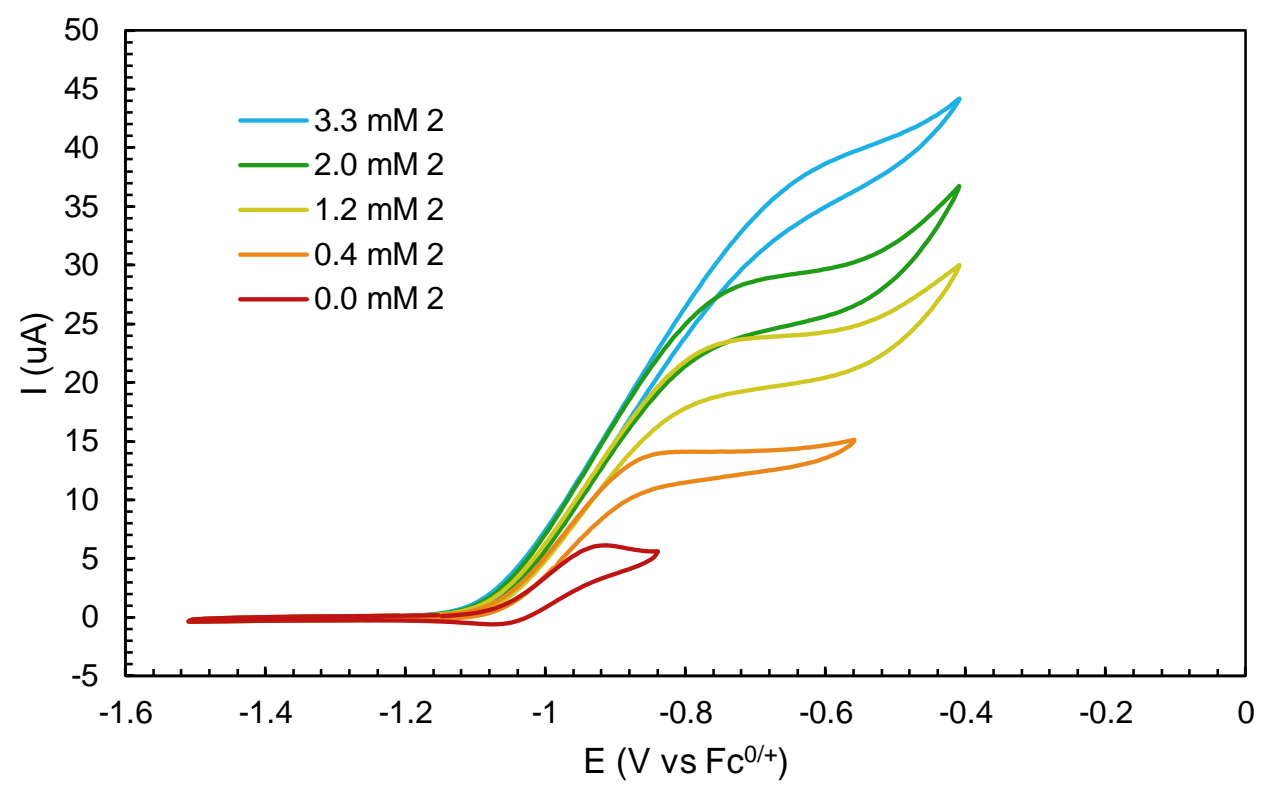

Figure S37. Titration of $\alpha$-rac-tocopherol $\mathbf{A r}^{1} \mathbf{O H}$ with $\operatorname{IrH} 2$ in the presence of isopropanol- $d 8(0.75 \mathrm{mM}$ $\mathrm{Ar}^{1} \mathbf{O H}, 23 \mathrm{mM} \mathrm{P}$-Et, $400 \mathrm{mM}$ isopropanol- $d 8$, $100 \mathrm{mM} \mathrm{NBu}_{4} \mathrm{BF}_{4}$ in THF, $v=25 \mathrm{mV} / \mathrm{s}$ )

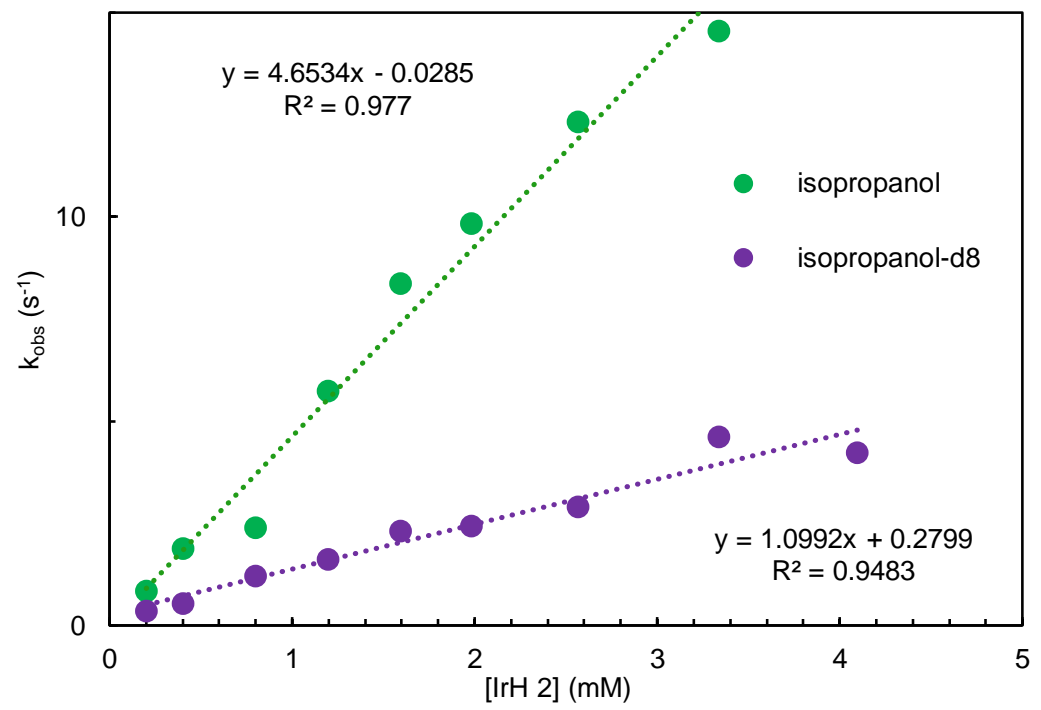

Figure S38. Comparison of the TOF vs $[\mathrm{IrH}]$ relationship for $\mathbf{A r}^{\mathbf{1}} \mathbf{O H}$-mediated electrocatalysis with isopropanol (green) and isopropanol- $d_{8}$ (purple) as the substrates. Isopropanol data reflects the plateau currents in the CVs in Figure S23, and the isopropanol- $d_{8}$ data reflects the plateau currents in the CVs in Figure S37.

$$
K I E_{\text {expt }}=\text { slope }_{H} /_{\text {slope }_{D}}=4.6534 / 1.0992=4.2
$$




\section{Foot-of-the-wave Analysis}

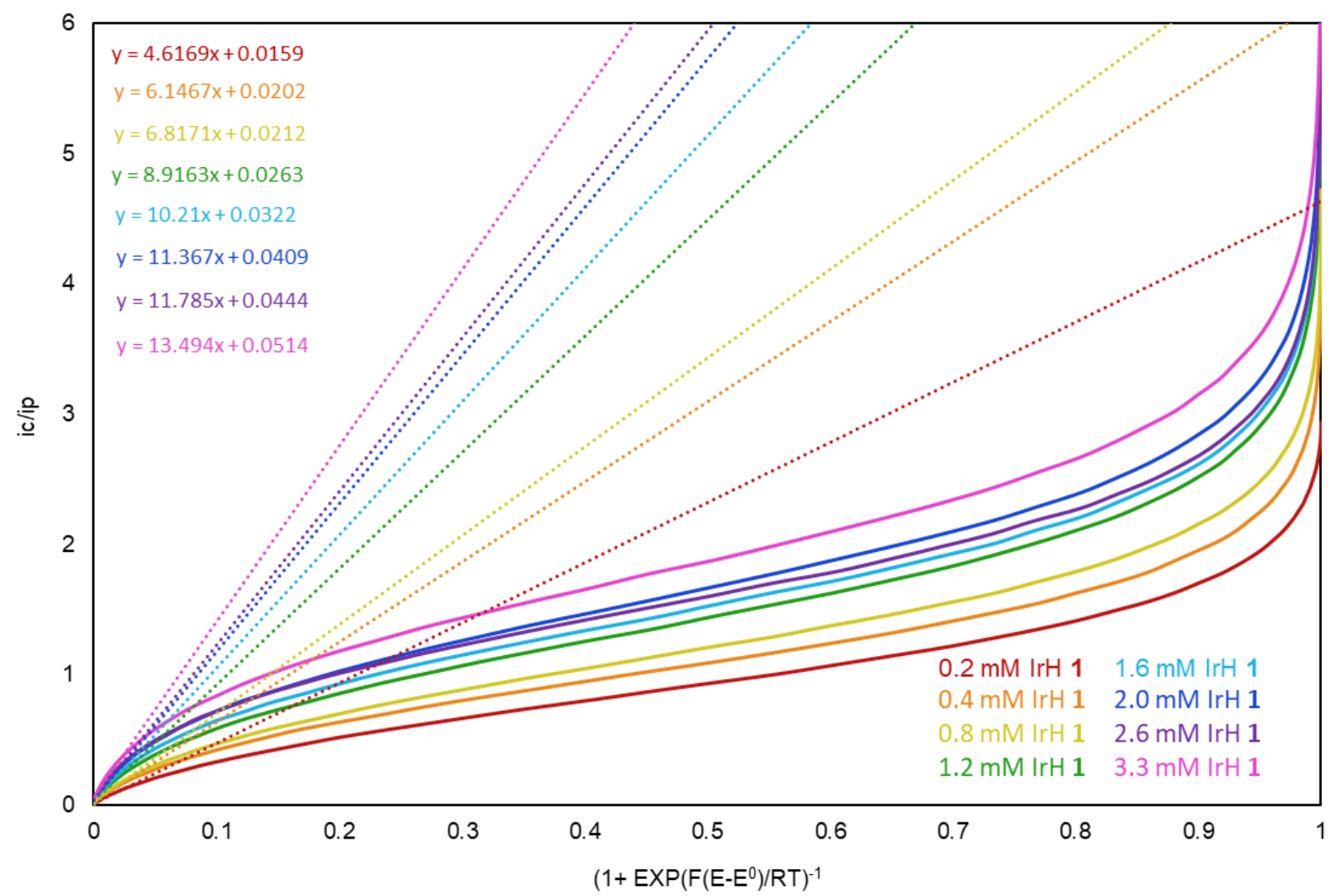

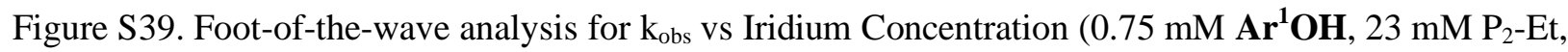
$400 \mathrm{mM}$ isopropanol, $100 \mathrm{mM} \mathrm{NBu}_{4} \mathrm{BF}_{4}$ in THF). These plots are derived from the voltammograms in Figure 10 in the main text. The trendlines were fit to only the initial linear portion of the curves. The potential at which the peak-shaped wave (in the absence of substrate) of the $\mathbf{A r}^{\mathbf{1}} \mathbf{O}$-/Ar $\mathbf{A r}^{\mathbf{1}} \mathbf{O} \cdot$ oxidation reaches one-half of its maximum current $\left(\mathrm{E}_{\text {half-max }}=-1.00 \mathrm{~V} \mathrm{vs} . \mathrm{Fc}^{0 /+}\right)$ was used as an approximation for $\mathrm{E}^{0}$. 


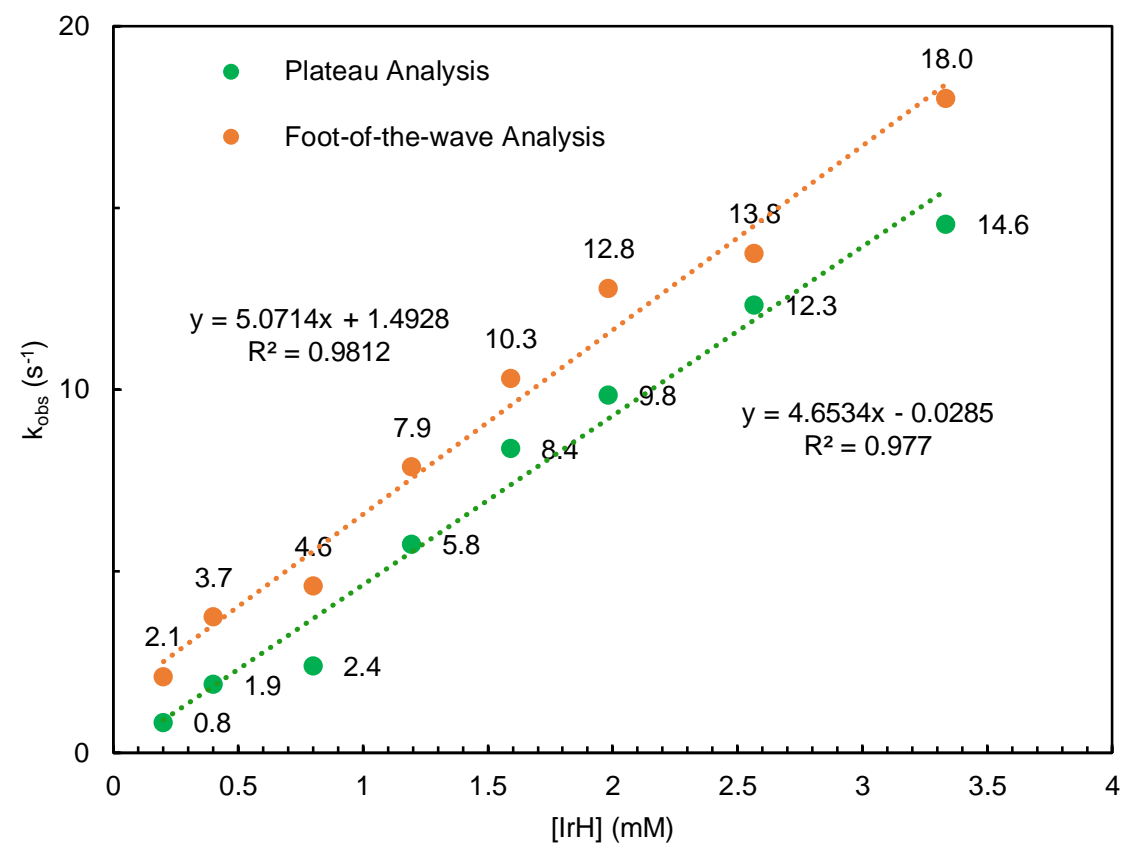

Figure S40. Comparison of TOF data derived from Foot-of-the-wave analysis and Catalytic Plateau analysis. The values of $\mathrm{k}_{\mathrm{obs}} /[\mathrm{IrN}]$ obtained from both analyses are within $10 \%$ of each other. The Foot-ofthe-wave data points are the slopes of the trendlines in Figure S39, and the catalytic plateau analysis data is reproduced from Figure 10 in the main text. 


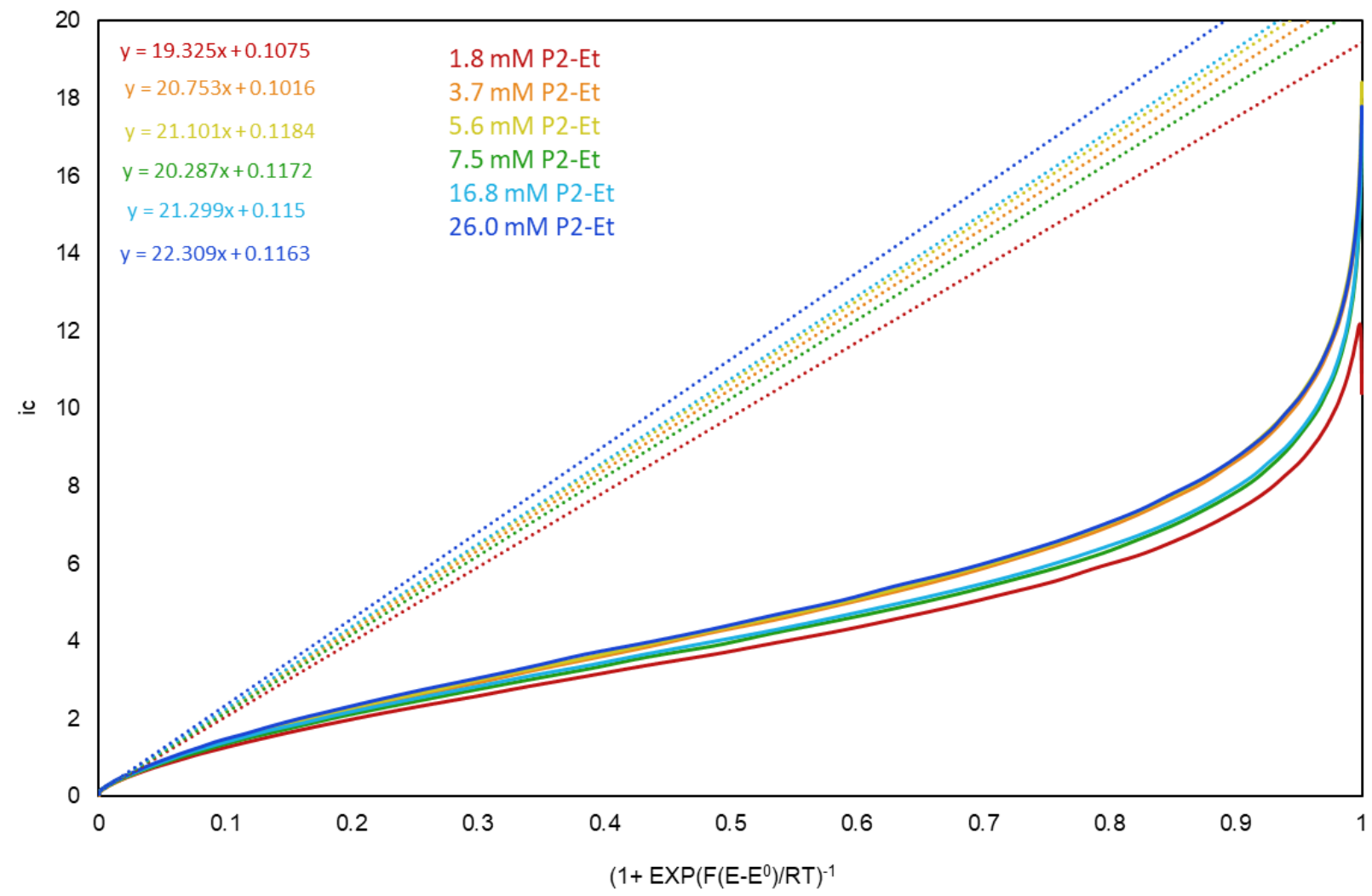

Figure S41. Foot-of-the-wave analysis ${ }^{7}$ for $\mathrm{i}_{\text {plateau }}{ }^{2}$ vs $\mathrm{P}_{2}$-Et Concentration (1.1mM IrH 1, $0.4 \mathrm{mM}$ $\mathrm{Ar}^{1} \mathbf{O H}, 420 \mathrm{mM}$ isopropanol, $100 \mathrm{mM} \mathrm{NBu}_{4} \mathrm{BF}_{4}$ in THF). These plots are derived from the voltammograms in Figure 13 in the main text. The trendlines were fit to only the initial linear portion of the curves. The potential at which the peak-shaped wave (in the absence of substrate) of the $\mathbf{A r} \mathbf{r}^{1} \mathbf{O}-/ \mathbf{A r}^{1} \mathbf{O}$. oxidation reaches one-half of its maximum current $\left(\mathrm{E}_{\text {half-max }}=-1.00 \mathrm{~V} \mathrm{vs} . \mathrm{Fc}^{0 /+}\right)$ was used as an approximation for $\mathrm{E}^{0}$. 


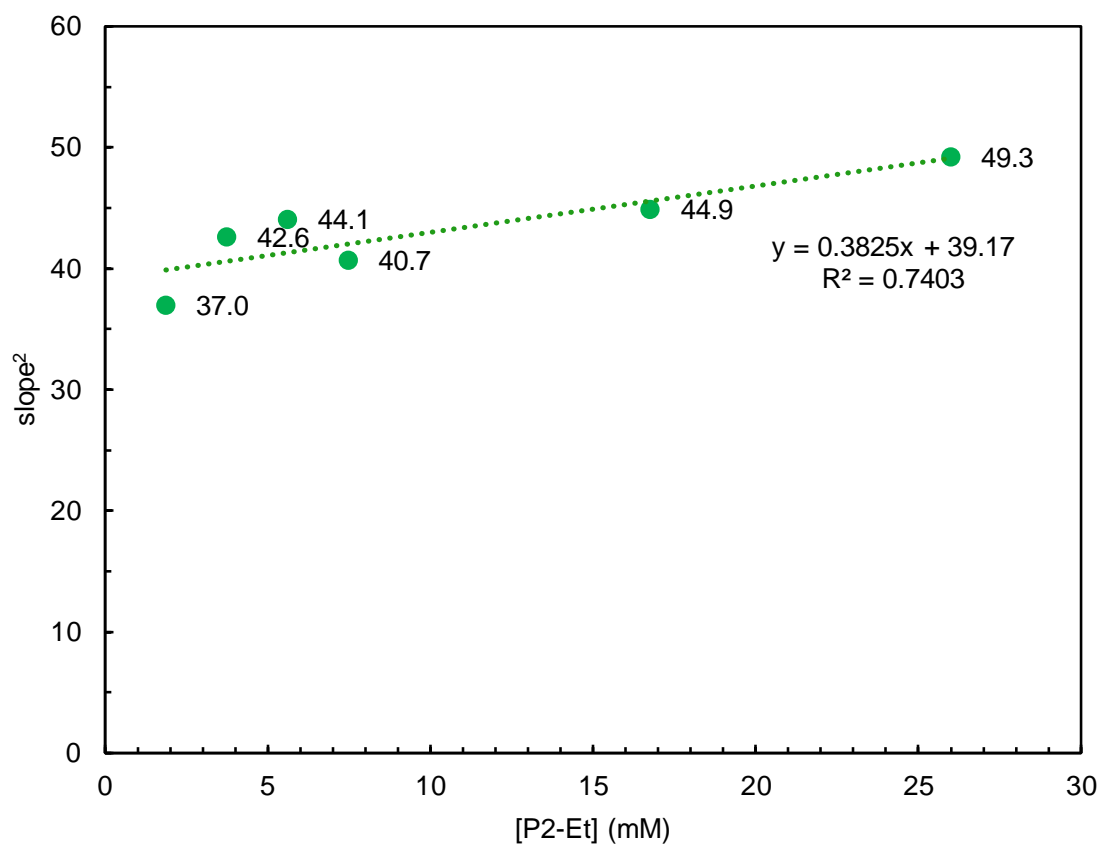

Figure S42. Foot-of-the-wave slope ${ }^{2}$ vs $\left[\mathrm{P}_{2}\right.$-Et]. The slope ${ }^{2}$ values are derived from the trendlines in Figure S41. Slope ${ }^{2}$ is directly proportional to $\mathrm{k}_{\mathrm{obs}}$ and is therefore sufficient to establish the order of the TOF in $\left[\mathrm{P}_{2}\right.$-Et]. In agreement with the plateau analysis in Figure 13 in the main text, the rate of catalysis is independent of base concentration, even at the lowest concentration of $\mathrm{P}_{2}$-Et $(1.9 \mathrm{mM})$ where the catalytic wave is peak-shaped. 
Ruling out ET-PT and PT-ET as mechanisms of IrH 2 oxidation by $\operatorname{Ar}^{1} \mathrm{O}^{\cdot}$

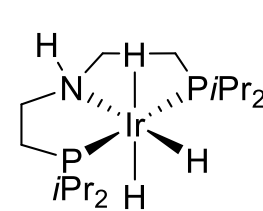

2<smiles>[R]C1([R])CCc2c([CH])c([O-])c(C)c(C)c2O1</smiles>

$\operatorname{Ar}^{1} \mathrm{O}$

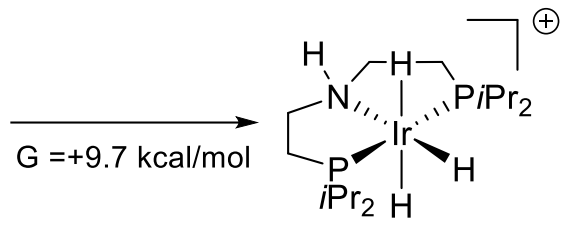

$\oplus$

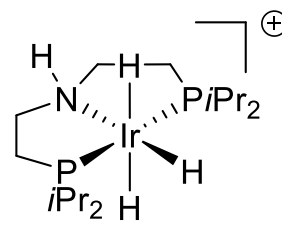<smiles>CCC(C)C(C)C[Pb]</smiles>

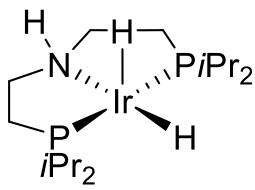

3<smiles>[R]C1(C)CCc2c(C)c(O)c(C)c(C)c2O1</smiles>

$\operatorname{Ar}^{1} \mathrm{O}^{-}$

Figure S43. Possible mechanism for the oxidation of $\operatorname{IrH} 2$ by $\operatorname{Ar}^{1} \mathbf{O} \cdot$ via ET-PT.

The estimate of the free energy change for the initial electron transfer $(+9.7 \mathrm{kcal} / \mathrm{mol})$ is calculated from the corresponding difference in onset potentials for the anodic oxidations of $\operatorname{IrH} 2\left(-0.65 \mathrm{~V} \mathrm{vs} \mathrm{Fc}^{0 /+}\right)$ and $\mathbf{A r}^{1} \mathbf{O}$ - $\left(-1.07 \mathrm{~V}_{\text {vs }} \mathrm{Fc}^{0 /+}\right.$ ) according to $\Delta \mathrm{G}=-\mathrm{nFE}$ (see below). This means that ET is probably the ratedetermining step in the catalytic cycle. However, we observed a substantial primary kinetic isotope effect (4.2) when we switched from protiated isopropanol to deuterated isopropanol, which suggests that an X$\mathrm{H}$ bond-breaking step is rate-determining. Usually, a small $\mathrm{KIE}$ is expected if ET is rate determining. This reasoning and method have been used many times previously to rule out discrete ET-PT mechanisms in favor of HAT. For instance, Meyer rules out ET-PT in favor of concerted PCET in the comproportionation of ruthenium oxo-and aquo- complexes because the initial ET would be endergonic by $+12.7 \mathrm{kcal} / \mathrm{mol}$ and the experimental KIE was $16 .{ }^{8}$ Similar logic is used to discount ET-PT in the oxidation of toluenes by permanganate where the initial ET is endergonic by $+44 \mathrm{kcal} / \mathrm{mol}$ and the KIE was $6.0 .^{9}$

However, there are some cases where ET-PT mechanisms give primary KIEs. If the initial ET is in fast pre-equilbirum and is followed by a rate-determining proton transfer, large primary KIEs can result. Two such examples include the oxidation of benzylic hydrocarbons by photoexcited quinones (KIE 1.73.0) and the oxidation of $p$-methoxytoluene by $\mathrm{CoW}_{12} \mathrm{O}_{40}{ }^{5-}$ (KIE 5-7). ${ }^{10-11}$ However, the rate-determining PT step would mean that the observed rate constant should depend on the base concentration. Indeed, the rate of methoxytoluene oxidation by the $\mathrm{CoW}_{12} \mathrm{O}_{40}{ }^{5-}$ is first order with respect to acetate. ${ }^{11}$ The rate of ECHAT with $\operatorname{IrH} \mathbf{2}$ and is $\mathbf{A r}^{1} \mathbf{O} \cdot$ is independent of base concentration; the plateau current is constant with $\mathrm{P}_{2}$-Et titration (Figure 13). Base independence in conjunction with a significant primary KIE lets us rule out the ET-PT pathway in Figure S43 as a possible mechanism.

$$
\begin{gathered}
E_{\text {onset }}\left(\boldsymbol{A r}^{\mathbf{1}} \boldsymbol{O}-/ \boldsymbol{A} \boldsymbol{r}^{\mathbf{1}} \boldsymbol{O} \cdot\right)=-1.07 V \text { vs } \mathrm{F}^{0 /+} \\
E_{\text {onset }}\left(\mathbf{2} / \mathbf{2}^{+}\right)=-0.65 V v s \mathrm{~F}^{0 /+} \\
\Delta G=-n F E \\
\Delta G=-(1)(96485 \mathrm{C} / \mathrm{mol})(-1.07 \mathrm{~V}-(-0.65 \mathrm{~V})) \\
\Delta G=40.5 \frac{\mathrm{kJ}}{\mathrm{mol}}=9.7 \mathrm{kcal} / \mathrm{mol}
\end{gathered}
$$




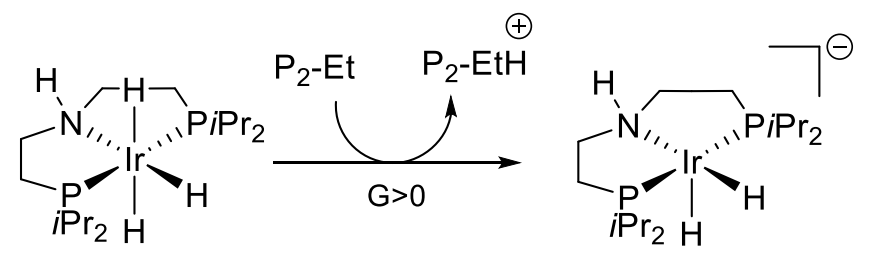

2

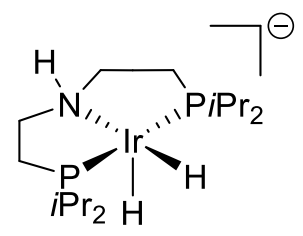<smiles>[R]C1(C)CCc2c(C)c([O-])c(C)c(C)c2O1</smiles>

Ar ${ }^{1} \mathbf{O}$<smiles>[R]C1(C)CCc2c(C)c([O-])c(C)c(C)c2O1</smiles>

$\mathrm{Ar}^{1} \mathrm{O}^{-}$

Figure S44. Possible mechanism for the oxidation of $\operatorname{IrH} 2$ by $\mathbf{A r}^{1} \mathbf{O} \cdot$ via PT-ET.

In the hypothetical PT-ET pathway in Figure S44, IrH 2 is first deprotonated by $\mathrm{P}_{2}$-Et, which is the strongest base present under electrocatalytic conditions. This is followed by ET from the anionic conjugate base of IrH 2 to the $\mathbf{A r}^{1} \mathbf{O}$ - radical to generate the $\mathbf{A r}^{1} \mathbf{O}$ - phenoxide. However, there is no strong base present in the nonelectrochemical catalytic reaction, which still proceeds rapidly (Figure 8). The phenoxyl

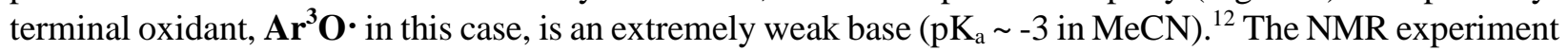
in Figure 14B showed that $\mathrm{IrH} 2$ is even less acidic than $\mathrm{P}_{2}-\mathrm{EtH}^{+}\left(\mathrm{pK}_{\mathrm{a}}>25.3\right.$ in THF, > 32.94 in acetonitrile). ${ }^{13}$ Initial proton transfer from the weakly acidic IrH $\mathbf{2}$ to the weakly basic $\mathbf{A} \mathbf{r}^{3} \mathbf{O} \cdot$ is so thermodynamically unfavorable that PT-ET can be safely ruled out as an operative mechanism for the net HAT from IrH 2 to phenoxyl radicals observed in Figure 8. 


\section{Calculation of Theoretical Maximum Kinetic Isotope Effects for $\mathrm{N}-\mathrm{H}$ and $\mathrm{Ir}-\mathrm{H}$ Homolyses}

Assuming a linear, symmetric transition state and no difference in zero-point energy at the transition state between protiated and deuterated cases, then the formula for the upper bound on KIE for an $\mathrm{X}-\mathrm{H}$ homolytic dissociation is:

$$
K I E=k_{H} k_{D}=e^{\frac{0.5 h c\left(1-\sqrt{\frac{\mu_{H}}{\mu_{D}}}\right) v_{H}}{k_{B} T}}
$$

Where $\mathrm{h}$ is the Planck Constant, $\mathrm{c}$ is the speed of light, $\mu_{\mathrm{H}}$ and $\mu_{\mathrm{D}}$ are the reduced masses of the $\mathrm{X}-\mathrm{H}$ and $\mathrm{X}-\mathrm{D}$ bonds, $v_{\mathrm{H}}$ is the IR stretching frequency of the $\mathrm{X}-\mathrm{H}$ bond, $\mathrm{k}_{\mathrm{B}}$ is the Boltzmann constant, and $\mathrm{T}$ is the temperature in Kelvin. The reduced mass ration for an iridium hydride is:

$$
\sqrt{\frac{\mu_{H}}{\mu_{D}}}=\sqrt{\frac{\frac{m_{H} m_{I r}}{m_{H}+m_{I r}}}{\frac{m_{D} m_{I r}}{m_{D}+m_{I r}}}}=\sqrt{\frac{\frac{1 * 192.217}{1+192.217}}{\frac{2 * 192.217}{2+192.217}}}=\sqrt{0.5026}
$$

Similarly, the reduced mass ratio for the $\mathrm{N}-\mathrm{H}$ bond is:

$$
\sqrt{\frac{\mu_{H}}{\mu_{D}}}=\sqrt{\frac{\frac{m_{H} m_{N}}{m_{H}+m_{N}}}{\frac{m_{D} m_{N}}{m_{D}+m_{N}}}}=\sqrt{\frac{\frac{1 * 14.007}{1+14.007}}{\frac{2 * 14.007}{2+14.007}}}=\sqrt{0.5333}
$$

The other constants $\left(\mathrm{h}, \mathrm{c}, \mathrm{k}_{\mathrm{B}}\right)$ are known and $\mathrm{T}=292 \mathrm{~K}$.

IrH 2 has three hydride frequencies: 2101, 1943, and $1702 \mathrm{~cm}^{-1} .2101 \mathrm{~cm}^{-1}$ is the stretch of the middle hydride trans to the amine. $1943 \mathrm{~cm}^{-1}$ is the symmetric stretch of the mutually trans hydrides, and $1702 \mathrm{~cm}^{-1}$ is the asymmetric stretch of those two hydrides. Therefore, an upper bound on KIE can be assigned for each of these modes. Table S1 contains the theoretical maximum KIEs for each mode.

Table S1: Theoretical Maximum KIEs for $\mathrm{Ir}-\mathrm{H}$ and $\mathrm{N}-\mathrm{H}$ Homolysis

\begin{tabular}{|l|c|c|}
\hline \multicolumn{1}{|c|}{ Mode } & $v_{H}\left(\mathrm{~cm}^{-1}\right)$ & Max KIE $(\mathrm{T}=292 \mathrm{~K})$ \\
\hline $\mathrm{Ir}-\mathrm{H}$ stretch trans to amine & 2101 & 4.36 \\
\hline Mutually trans H-Ir-H symmetric stretch & 1943 & 3.90 \\
\hline Mutually trans H-Ir-H asymmetric stretch & 1702 & 3.40 \\
\hline N-H Stretch & 3140 & 8.01 \\
\hline
\end{tabular}




\section{Cyclic Voltammetry of ECHAT in Neat Isopropanol}

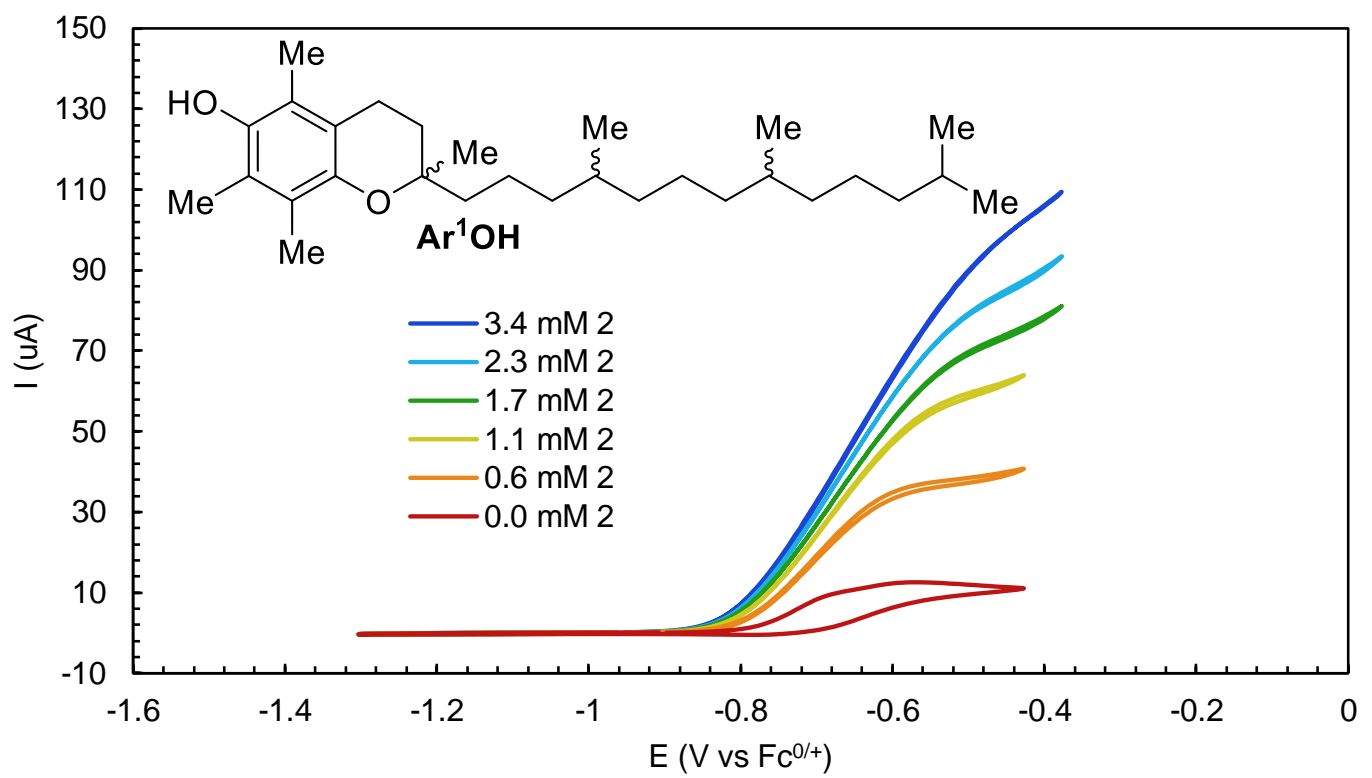

Figure S45. Titration of $\alpha$-rac-tocopherol $\mathbf{A r}^{1} \mathbf{O H}$ with $\operatorname{IrH} \mathbf{2}$ in neat isopropanol (1.8 $\mathrm{mM} \mathrm{Ar}^{\mathbf{1}} \mathbf{O H}, 69$ $\mathrm{mM} \mathrm{P}_{2}-\mathrm{Et}, 100 \mathrm{mM} \mathrm{NBu}_{4} \mathrm{BF}_{4}$ in neat isopropanol, $v=25 \mathrm{mV} / \mathrm{s}$ )

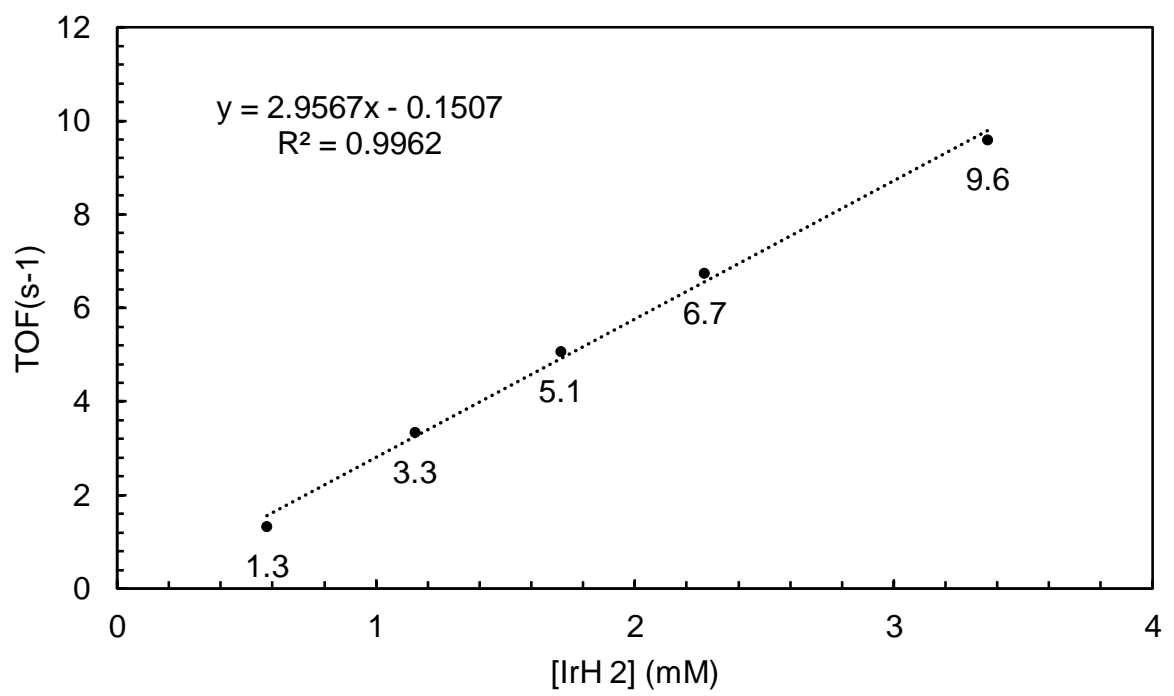

Figure S46. TOF vs [IrH 2] for Ar $\mathbf{r}^{\mathbf{1}} \mathbf{O H}-$ mediated ECHAT in neat isopropanol (TOF reflects plateau current data in Figure S45) (1.8 $\mathrm{mM} \mathrm{Ar}^{1} \mathbf{O H}, 69 \mathrm{mM} \mathrm{P}_{2}$-Et, $100 \mathrm{mM} \mathrm{NBu}_{4} \mathrm{BF}_{4}$ in neat isopropanol, $v=25$ $\mathrm{mV} / \mathrm{s}$ ) 


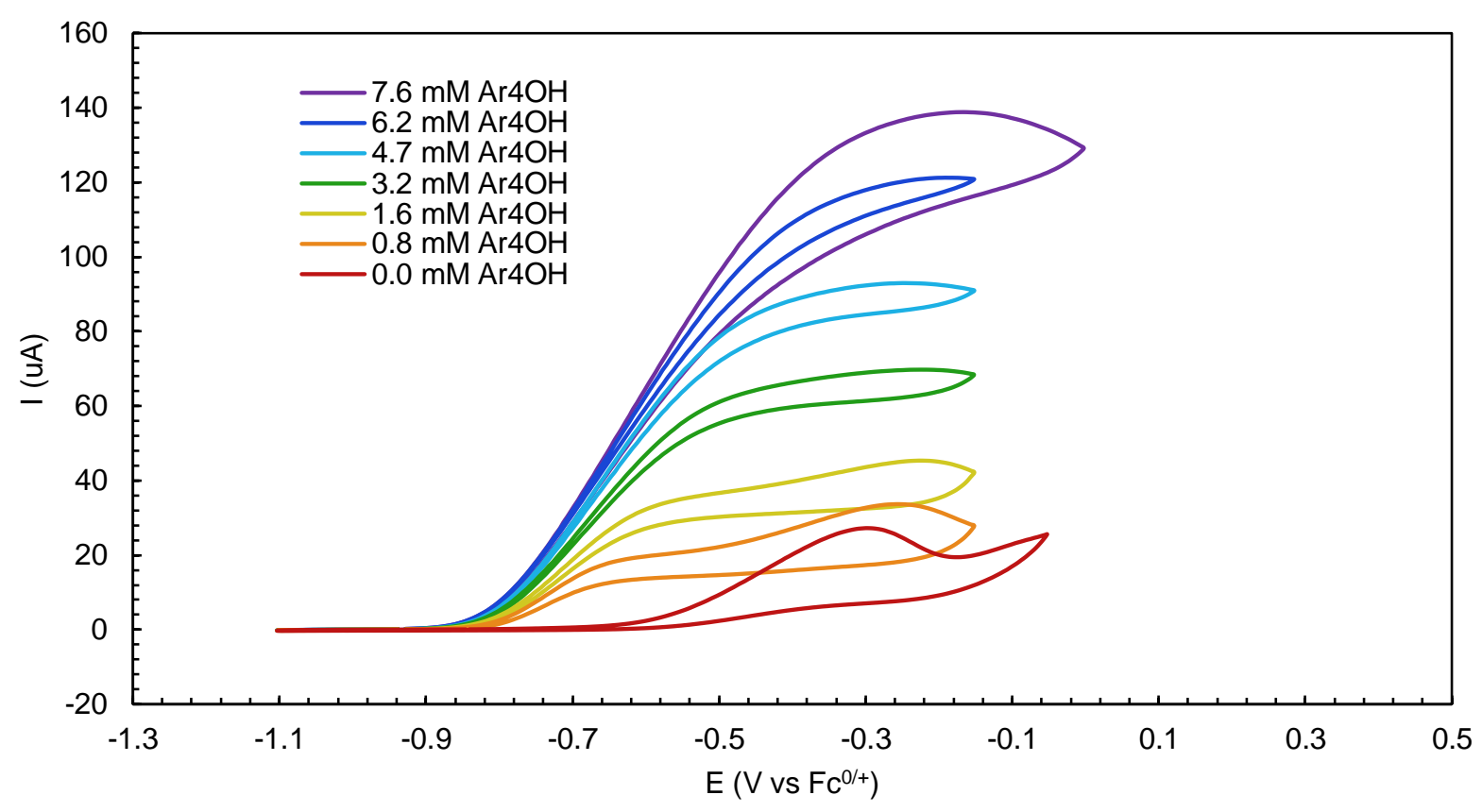

Figure S47. Titration of IrH 2 with $\alpha$-rac-tocopherol $\mathbf{A r}^{1} \mathbf{O H}$ for ECHAT in neat isopropanol (1.1 mM IrH 2, $71 \mathrm{mM} \mathrm{P}_{2}$-Et, $100 \mathrm{mM} \mathrm{NBu}_{4} \mathrm{BF}_{4}$ in neat isopropanol, $v=25 \mathrm{mV} / \mathrm{s}$ )

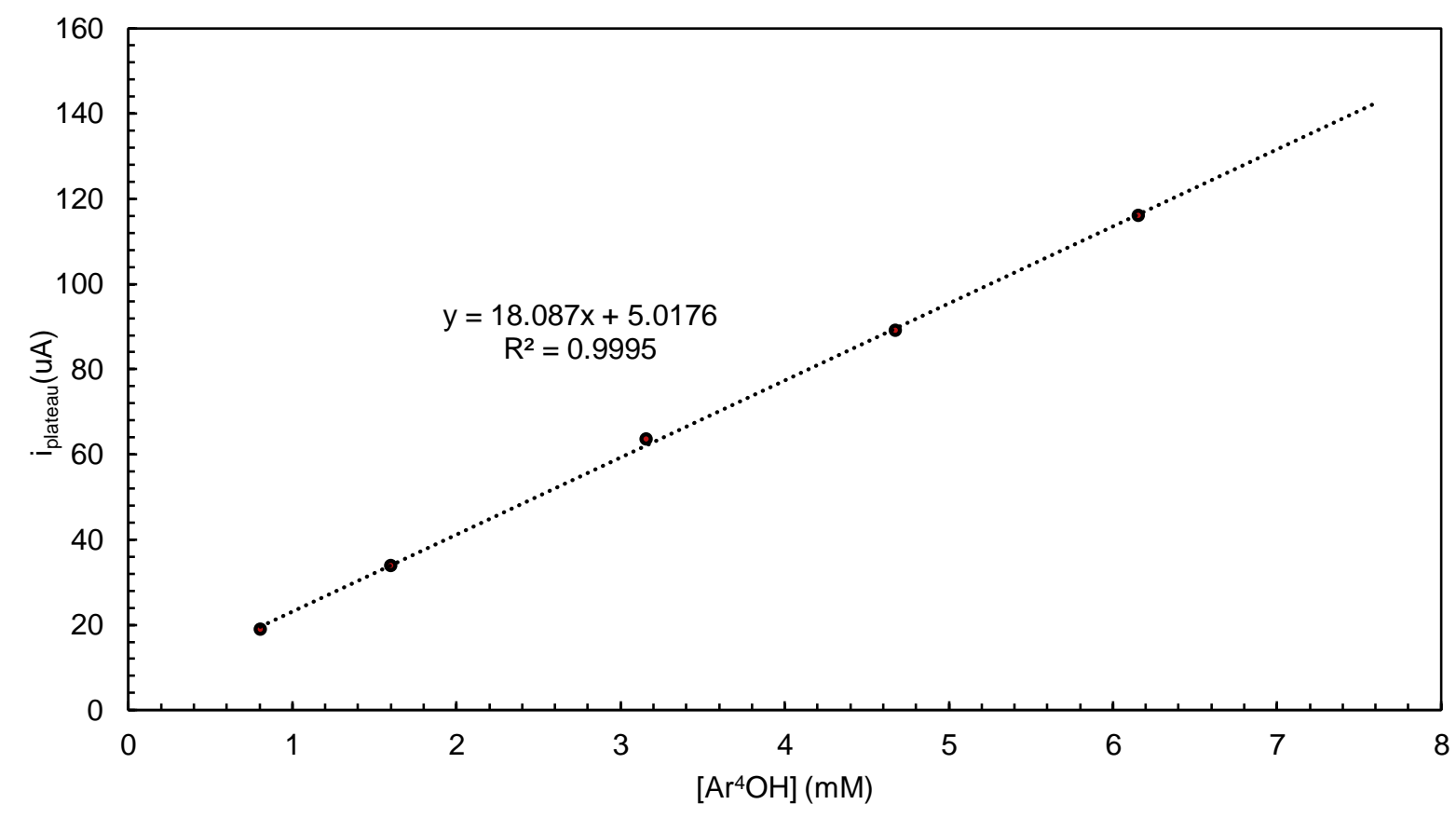

Figure S48. $\mathrm{I}_{\text {plateau }}$ vs. $\left[\mathbf{A r}^{1} \mathbf{O H}\right.$ ] for ECHAT in neat isopropanol (Plateau current data taken from Figure S47) $\left(1.1 \mathrm{mM} \mathrm{IrH} \mathrm{2,} 71 \mathrm{mM} \mathrm{P}{ }_{2}-\mathrm{Et}, 100 \mathrm{mM} \mathrm{NBu}_{4} \mathrm{BF}_{4}\right.$ in neat isopropanol, $\left.v=25 \mathrm{mV} / \mathrm{s}\right)$ 


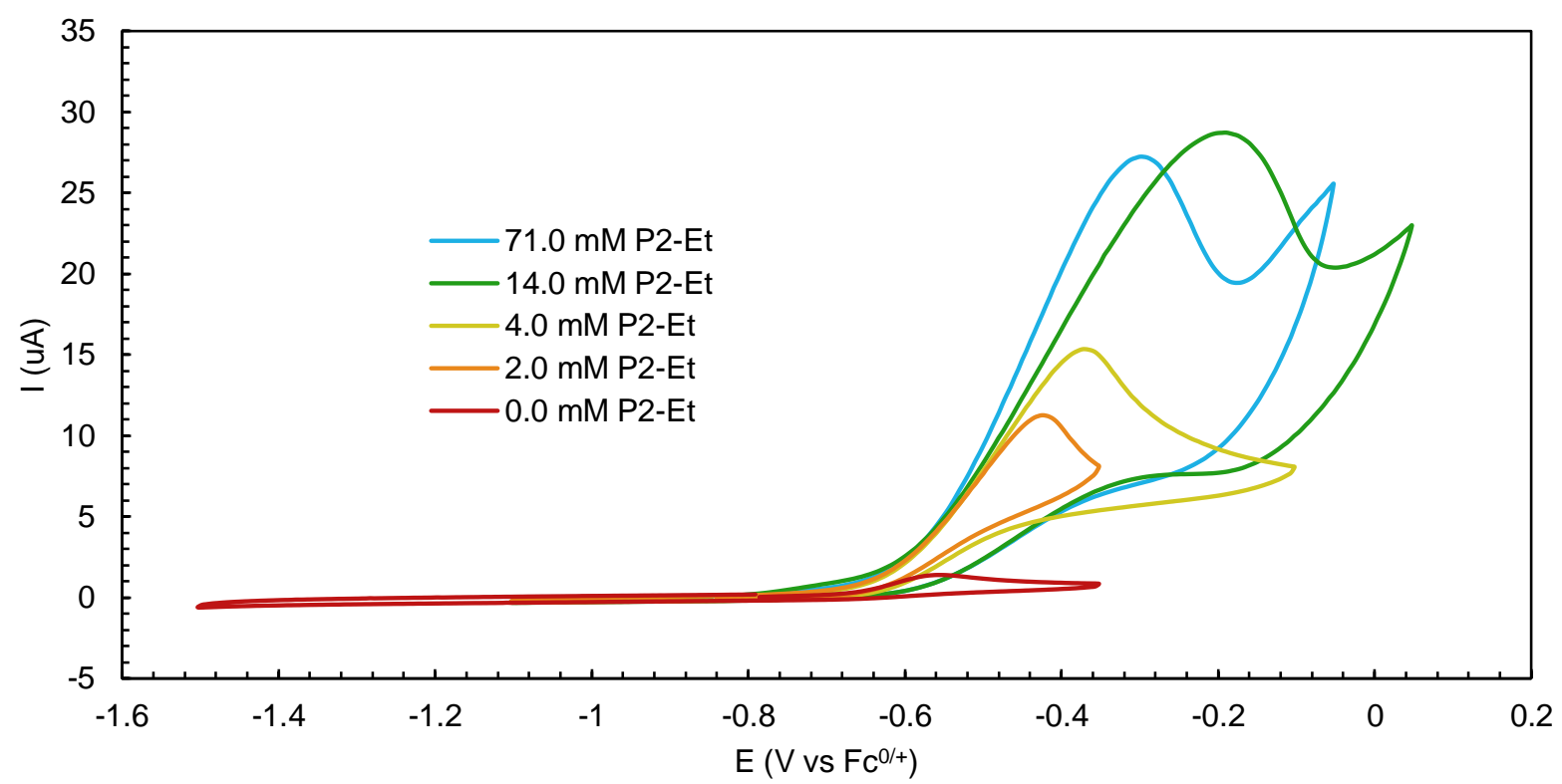

Figure S49. Titration of IrH 2 with $\mathrm{P}_{2}$-Et for ECAT in neat isopropanol $\left(1.1 \mathrm{mM} \mathrm{IrH} \mathrm{2,} 100 \mathrm{mM} \mathrm{NBu}_{4} \mathrm{BF}_{4}\right.$ in neat isopropanol, $v=25 \mathrm{mV} / \mathrm{s}$ )

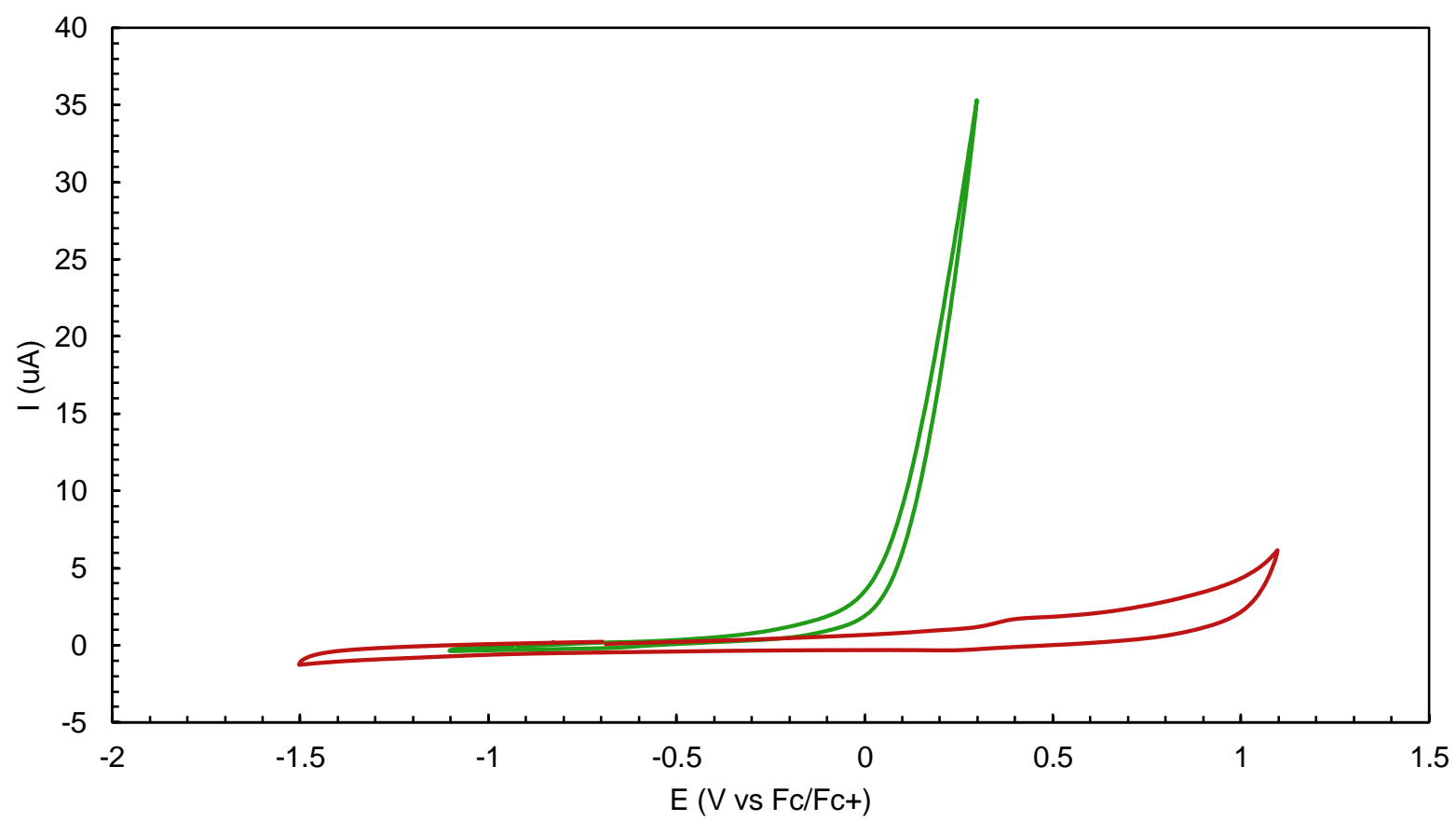

Figure S50. Blank voltammograms without (red) and with (green) $25 \mathrm{mM} \mathrm{P}_{2}$-Et base $\left(100 \mathrm{mM} \mathrm{NBu}_{4} \mathrm{BF}_{4}\right.$ in neat isopropanol, $v=25 \mathrm{mV} / \mathrm{s}$ ) 


\section{References}

1. Clarke, Z. E.; Maragh, P. T.; Dasgupta, T. P.; Gusev, D. G.; Lough, A. J.; Abdur-Rashid, K., A Family of Active Iridium Catalysts for Transfer Hydrogenation of Ketones. Organometallics 2006, 25 (17), 4113-4117.

2. Manner, V. W.; Markle, T. F.; Freudenthal, J. H.; Roth, J. P.; Mayer, J. M., The first crystal structure of a monomeric phenoxyl radical: 2,4,6-tri-tert-butylphenoxyl radical. Chemical Communications 2008, (2), 256-258.

3. Costentin, C.; Savéant, J.-M., Multielectron, Multistep Molecular Catalysis of Electrochemical Reactions: Benchmarking of Homogeneous Catalysts. ChemElectroChem 2014, 1 (7), 1226-1236.

4. Badalyan, A.; Stahl, S. S., Cooperative electrocatalytic alcohol oxidation with electron-protontransfer mediators. Nature 2016, 535, 406.

5. Lee, K. J.; Elgrishi, N.; Kandemir, B.; Dempsey, J. L., Electrochemical and spectroscopic methods for evaluating molecular electrocatalysts. Nature Reviews Chemistry 2017, 1, 0039.

6. Rountree, E. S.; McCarthy, B. D.; Eisenhart, T. T.; Dempsey, J. L., Evaluation of Homogeneous Electrocatalysts by Cyclic Voltammetry. Inorganic Chemistry 2014, 53 (19), 9983-10002.

7. Costentin, C.; Drouet, S.; Robert, M.; Savéant, J.-M., Turnover Numbers, Turnover Frequencies, and Overpotential in Molecular Catalysis of Electrochemical Reactions. Cyclic Voltammetry and Preparative-Scale Electrolysis. Journal of the American Chemical Society 2012, 134 (27), 11235-11242.

8. $\quad$ Binstead, R. A.; Moyer, B. A.; Samuels, G. J.; Meyer, T. J., Proton-coupled electron transfer between $[\mathrm{Ru}(\mathrm{bpy}) 2(\mathrm{py}) \mathrm{OH} 2] 2+$ and $[\mathrm{Ru}(\mathrm{bpy}) 2(\mathrm{py}) \mathrm{O}] 2+$. A solvent isotope effect $(\mathrm{kH} 2 \mathrm{O} / \mathrm{kD} 2 \mathrm{O})$ of 16.1 . Journal of the American Chemical Society 1981, 103 (10), 2897-2899.

9. $\quad$ Gardner, K. A.; Kuehnert, L. L.; Mayer, J. M., Hydrogen Atom Abstraction by Permanganate: Oxidations of Arylalkanes in Organic Solvents. Inorganic Chemistry 1997, 36 (10), 2069-2078.

10. Bockman, T. M.; Hubig, S. M.; Kochi, J. K., Kinetic Isotope Effects for Electron-Transfer Pathways in the Oxidative C-H Activation of Hydrocarbons. Journal of the American Chemical Society 1998, 120 (12), 2826-2830.

11. Eberson, L., Electron-transfer reactions in organic chemistry. 4. A mechanistic study of the oxidation of p-methoxytoluene by 12-tungstocobalt(III)ate ion. Journal of the American Chemical Society 1983, 105 (10), 3192-3199.

12. Warren, J. J.; Tronic, T. A.; Mayer, J. M., Thermochemistry of proton-coupled electron transfer reagents and its implications. Chem Rev 2010, 110 (12), 6961-7001.

13. Tshepelevitsh, S.; Kütt, A.; Lõkov, M.; Kaljurand, I.; Saame, J.; Heering, A.; Plieger, P. G.; Vianello, R.; Leito, I., On the Basicity of Organic Bases in Different Media. European Journal of Organic Chemistry 2019, 2019 (40), 6735-6748. 